


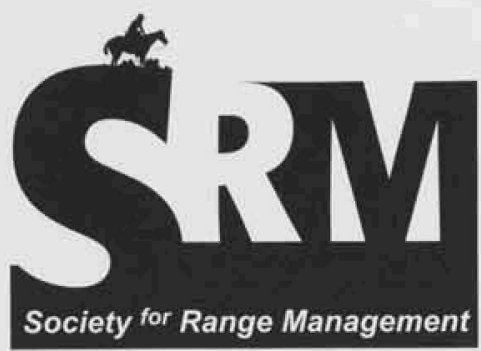

\author{
President \\ RODNEY K. HEITSCHMIDT \\ USDA-ARS \\ Ft. Keogh LARRL \\ Rt 1, Box 2021 \\ Miles City, Montana 59301-9801 \\ 1st Vice-President \\ BOB BUDD \\ Red Canyon Ranch \\ 350 Red Canyon Rd \\ Lander. Wyoming 82520-9417 \\ 2nd Vice-President \\ MORT KOTHMANN \\ Texas A\&M University \\ Dept. Rangeland Ecology \& Mgt. \\ College Stattion. Texas 77843-0001 \\ Executive Vice-President \\ SAM ALBRECHT \\ 445 Union Blvd. Suite 230 \\ Lakewood, Colorado 80228-1259 \\ (303) $986-3309$ \\ Fax: (303) 986-3892 \\ e-mail address: \\ sminden@ix.netcom.com \\ Directors \\ 2000-2002 \\ RICHARD H. HART \\ USDA-ARS \\ High Plains Grasslands Station \\ 8408 Hildreth Rd. \\ Cheyenne, Wyoming 82009-8809 \\ DON KIRBY \\ North Dakota State University \\ Animal \& Range Science \\ Fargo, North Dakota 58105 \\ 2001-2003 \\ JOHN TANAKA \\ Eastem Oregon Agr. Res. Genter-Union \\ P.O. Box E \\ Union, Oregon 97883 \\ GREG TEGART \\ BCMAFF \\ 1690 Powick Rd, Suite 2000 \\ Kelowna, BC V1X 7 G5 \\ CANADA

\section{2-2004} \\ JOHN MALECHEK \\ Utah State University \\ Dept. of Rangeland Resources \\ UMC 5230 \\ Logan, Utah 84322-0001 \\ MARTIN VAVRA \\ EOARC \\ HC 71 Box 451, Hwy 205 \\ Burns, Oregon $97720-9807$
}

The term of office of all elected officers and dinectors begins in February of each year during the Society's Annual Meeting

SRM Office Staff, 445 Union Blvd, Suite 230. Lakewood, Colorado 80228: Telephone (303) 986-3309: Fax (303) 9863892: e-mail address: srmden@rangelands.org home page www.rangelands.org

AARON BARR - Membership Services Manager NATALIE BOLLEURS - Office Service Assistant ANN HARRIS - Director of Administration/Programs PATTY RICH - Production Editor

KIRSTEN TARDY - Director of Accounting \& Sales

\section{The Society for Range Management}

The Society for Range Management founded in 1948 as the American Society of Range Management, is a nonprofit association incorporated under the laws of the State of Wyoming. It is recognized exempt from Federal income tax, as a scientific and educational organization, under the provisions of Section 501 (c) (3) of the Internal Revenue Code, and also is classed as a public foundation as described in Section 509 (a) (2) of the Code. The name of the Society was changed in 1971 by amendment of the Articles of Incorporation.

The objectives for which the corporation is established are:

-to properly take care of the basic rangeland resources of soil, plants and water:

-to develop an understanding of range ecosystems and of the principles applicable to the management of range resources;

-to assist all who work with range resources to keep abreast of new findings and techniques in the science and art of range management;

- to improve the effectiveness of range management or obtain from range resources the products and values necessary for man's welfare:

-to create a public appreciation of the economic and social benefits to be obtained from the range environment:

- to promote professional development of its members.

Membership in the Society for Range Management is open to anyone engaged in or interested in any aspect of the study, management, or use of rangelands. Please contact the Executive Vice-President for details.

\section{Rangelands}

Rangelands serves as a forum for the presentation and discussion of facts, ideas, and philosophies pertaining to the study, management, and use of rangelands and their several resources. Accordingly, all material published herein is signed and reflects the individual views of the authors and is not necessarily an official position of the Society. Manuscripts from any source - nonmembers as well as members-are welcome and will be given every consideration by the editors. Rangelands is the nontechnical counterpart of the Journal of Range Management; therefore, manuscripts and news items submitted for publication in Rangelands should be in nontechnical nature and germane to the broad field of range management. Editorial comment by an individual is also welcome and, subject to acceptance by the editor, will be published as a "Viewpoint."

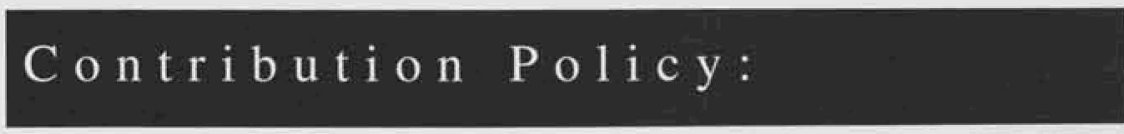

The Society for Range Management may accept donations of real and/or personal property subject to limitations set forth by State and Federal law. All donations shall be subject to management by the Executive Vice President as directed by the Board of Directors and their discretion in establishing and maintaining trust, memorials, scholarships or other types of funds. Individual endowments for designated purposes can be established according to Society policies. Gifts, bequests, legacies, devises, or donations not intended for establishing designated endowments will be deposited into the SRM Endowment Fund. Donations or request for information on Society policies can be directed to the Society for Range Management, Executive Vice President, 445 Union Blvd., Suite 230, Lakewood, Colorado 80228 . We recommend that donors consult Tax Advisors in regard to any tax consideration that may result from any donation. 


Volume 24 No. 3
June 2002
Published bimonthly-February, April, June, August,
October. December
Copyright 2002 by the Society for Range Management
Editor/Copy Editor
GARY/JO FRASIER
7820 Stag Hollow
Loveland, Colorado 80538
(970) 663-3094
E-Mail: gfrasier@lamar.colostate.edu
Managing Editor
KINDRA GORDON
P.O. Box 645
Spearfish, South Dakota 57783
(605) 722-7699
E-Mail: kindras@gordonresources.com
Production Editor
PATTY RICH
3059A Hwy 92
Hotchkiss, Colorado $81419-9548$
(970) 872-5932
E-Mail: prich $@$ starband.net

Book Review Editor

DAVID L. SCARNECCHIA

Dept. Natural Res. Sci.

Washington State University

Pullman, Washington $99164-6410$

E-Mail: scarneda@mail.wsu.edu

Editorial Board

2000-2002

LYNN HUNTSINGER, El Cenito, California

JOHN MITCHELL, Fort Collins, Colorado

KIETH SEVERSON, Isle, Minnesota

AMY SMITH. Burns, Oregon

2001-2003

DAVID BRADFORD, Paonia, Colorado

RANDEL DONGES, Dalhart, Texas

MICHAEL FRISINA, Butte, Montana

ART MEEN, Fredonia, Arizona

2002-2004

JON BATES, Burns, Oregon

JAMES BRUNNER, Medford, Oregon

JAY DAVISON, Fallon, Nevada

JERRY DODD, Lawton, Oklahoma

MARIL YN J. SAMUEL, Lehigh Acres. Florida

TOM MONOCO, Logan, Utah

INDIVIDUAL SUBSCRIPTION is by membership in the Society for Range Management.

LIBRARY or other INSTITUTIONAL SUBSCRIPTIONS, on a calendar year basis, are $\$ 65.00$ in the United States, $\$ 89.00$ in all other countries. Payments from outside the United States should be remitted in US dollars by international money order or draft on a New York bank.

BUSINESS CORRESPONDENCE, concerning subscriptions, advertising, back issues, and related matters, should be addressed to 445 Union Blvd., Suite 230, Lakewood, Colorado 80228. Phone 303-986-3309.

EDITORIAL CORRESPONDENCE, concerning manuscripts or other edited matters, should be addressed to the Technical Editor, 7820 Stag Hollow Road Loveland, Colorado 80538.

RANGELANDS (ISSN-0190-0528) is published six times yearly (February, April. June, August, October, and December) by the Society for Range Management, 445 Union Blvd., Suite 230, Lakewood, Colorado 80228. Phone 303 986-3309. PERIODICALS POSTAGE paid at Denver. Colorado and additional offices.

POSTMASTER; Return entire journal with address change-Address Service Requested-to Society for Range Management, 445 Union Blvd.. Suite 230. Lakewood, Colorado 80228 .

PRINTED IN THE USA

\section{Rangelands}

\section{FEATURE ARTICLES}

\author{
An Eye For Grass \\ by Kindra Gordon
}

Will California's Landscapes Keep Working?

by Sheila Barry and Lynn Huntsinger . . . . . . . . . . . . 6

Cows \& Cash

by Rob Pearce, Don Henderson, Sandy Jonkey,

Gabe Fogarty, and Tim Dardin . . . . . . . . . . . . . . . . . . . . . 11

Minimizing Wildfire Risk With Grazing

by Travis Brown ........................ 17

Rangelands In Jordan And Tunisia

by Taoufik Ksiksi, Mohamed K. J. El-Shatnawi, and

Salah Chouki ...............................19

Goats And The Need For Range Management In Mexico by Edmundo Castellanos-Perez, Manuel Valencia-Castro Jesus J. Quiñones-Vera . . . . . . . . . . . . . . . . . . . . . . . . .

Assessing Browse Trend At The Landscape Level

Part 1: Preliminary Steps and Field Survey by Richard B. Keigley, Michael R. Frisina, and Craig W. Fager ........................ 28

Assessing Browse Trend At The Landscape Level

Part 2: Monitoring

by Richard B. Keigley, Michael R. Frisina, and Craig W.

Fager ..................................

\section{DEPARTMENTS}

2 EVP Comments

39 Interpretive Summaries

43 Browsing the Literature

52 Book Reviews

55 BOD And AC Highlights
48 Life Members
23 Resource Roundup

42 Listening To The Land

45 Letters To The Editor

50 Viewpoint

54 Open Letter to SRM

\section{COVER}

Front Cover: Mule deer buck and wild turkeys are alert to interlopers on their sunny

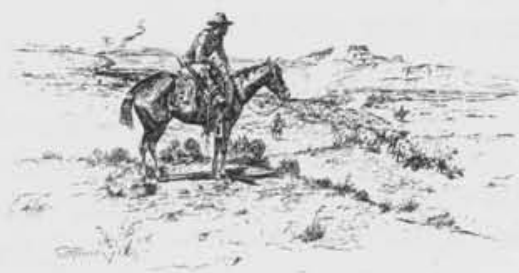
pasture near Ekalaka, Montana. Back Cover: Summer colors in a fall pasture near Ekalaka, Montana. Pictured are Lupinus argenteus and Echinacea angustifolia. Photos by Chad Prosser, Sidney, Montana. 


\section{EVP's Comments}

\section{Rangelands Fully Engaged}

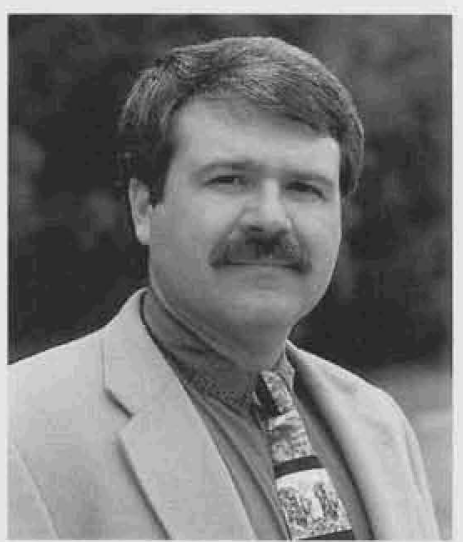

There are times when one feels that taking care of business is not being done very effectively. Yes, the job is getting done, but the mechanism is missing a tooth or two on some of the gears. Efficiency is not being optimized. You can only run at two-thirds throttle.

SRM is not at that place. SRM is fully engaged. There are several reasons for this.

One - with the addition of Leonard Jolley, NRCS, to the SRM office, we are now able to cover more technical projects. The Certified Professional in Rangeland Management program is now getting the full attention that it deserves, and an overall communication and marketing plan is being developed.

Two - The strategic plan is approved and in place. As we used to say in the Air Force - all thrust and no vector will never get you where you need to go. We now have a vector. And I quote: The Mission of the Society for Range Management is to promote the professional development and continuing education of members and the public and the stewardship of rangeland resources. The Vision of the Society for Range Management is a welltrained and highly motivated group of professionals and rangeland users working with productive, sustainable rangeland ecosystems. We are focusing on member services, professional education, external communications, rangeland science, public policies, and quality administration. Certainly a full plate, and certainly a very big challenge, but now the direction is very well identified.

Three - Staff and tools are in place to meet the mission. We have a great staff. They are dedicated and hard working - I couldn't ask for better. The new website is a valuable membership and communication tool. Listservs are being created for special interest groups, task forces, and committees to increase communication and productivity. Our publications are being improved.

What about the future? Can we do better than fully engaged? I am not sure, but there are several events that are certain to help. The Bureau of Land Management has signed an agreement to assign a person to the SRM office - most of the details are worked out and we expect this person to be on board this fall. We have opened an SRM office in Washington D.C. As explained in my June Trail Boss News article, this will increase our visibility and effectiveness on the national stage.

The new Farm Bill has been signed and now gets to be implemented. There are some interesting challenges in the third party vendor arena, the Grassland Reserve Program, and an overall increase in spending for conservation. The Society has a lot of good work to do in the future. It should be a great ride. 


\title{
An Eye For Grass
}

\section{SRM bestows Oklahoma couple with "Outstanding Grazing Lands Managers" award.}

\author{
By Kindra Gordon
}

Like many lifelong ranchers, John and Tamra Phelan have always recognized the importance of being stewards of the land. But recently, the stewardship efforts of this Mountain Park, Oklahoma couple earned them special recognition by the Society for Range Management (SRM) when they were awarded the honor of "Outstanding Grazing Lands Managers." This is the first year that SRM has presented such an award, but the organization plans to make it an annual affair.

The Phelan's were selected because of their long-standing commitment to implementing sound range and wildlife management practices on their Oklahoma ranch. Here is their story:

John's keen range management knowledge is the result of a lifelong affiliation with ranching. He is a 1973 graduate of the ranch management program at Texas Christian University (TCU) and worked for several large ranches in Texas and Oklahoma before going into business for himself. Of his interest in range resources, he says, "My dad lit the flame and John "Chip" Merrill fanned it." Merrill, a past SRM president, was director of the TCU ranch management program for the better part of 30 years.

Over the years, John has also worked closely with range professionals from the NRCS, Extension Service, Noble Foundation and Holistic Resource Management.

Initially, the Phelan's operated a traditional cow/calf operation. But several years ago, they elected to switch to an all stocker program using high-intensity rotational grazing. John says he felt this change would help them meet their primary goal of maintaining a high quality of life and minimal debt while conserving the natural resources on the ranch. They've been pleased with the results.

\section{The Phelan System}

The Phelan's use a high intensity rotation grazing system with their stocker program. They have approximately 25 permanent paddocks on their native range that they rotate their animals through. The size of the paddocks vary due to rough terrain, but average around 80 acres. John begins re-

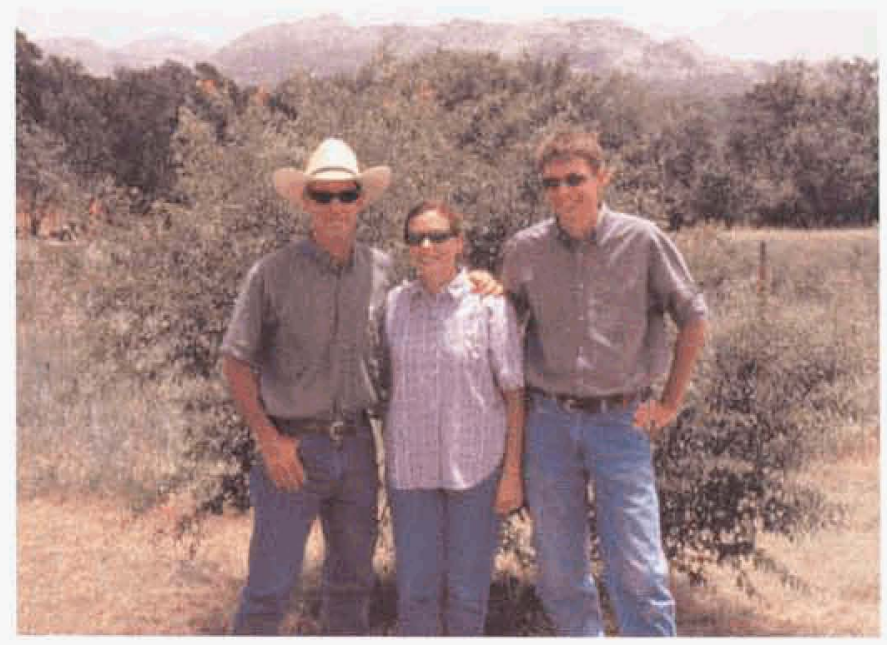

The Phelan family at their ranch in Oklahoma.

ceiving cattle in mid-November to early December and sells in late July or early August depending on the amount of grass and condition of the cattle.

"We typically buy thin, crossbred cattle with some age. They are not pretty cattle. We make lemonade out of lemons, that's what this business is all about," John says. "I buy steers that are economical and that can live off dead grass and a little protein supplement through the winter. Then when spring comes and they are grazing high quality native range, they turn wrong side out. The compensatory gain is amazing."

During the winter months when the grass is dormant, the stocker cattle will typically make one pass through each paddock, staying in each pasture from 5 to 10 days. At this time, the animals are supplemented with $2 \mathrm{lbs}$./day of $25 \%$ (crude protein) range cubes and gradually increased to 3 lbs./day, depending on weather conditions.

To efficiently utilize the dormant winter forage-and cut winter feed costs, John often subdivides his permanent paddocks with temporary electric fencing (single strand poly wire).

"I do a better job of rationing out the dormant grass by doing this," he says of the subdivision of paddocks. He says keeping the cattle in a small area and essentially forcing them to utilize the dormant forage before moving them 


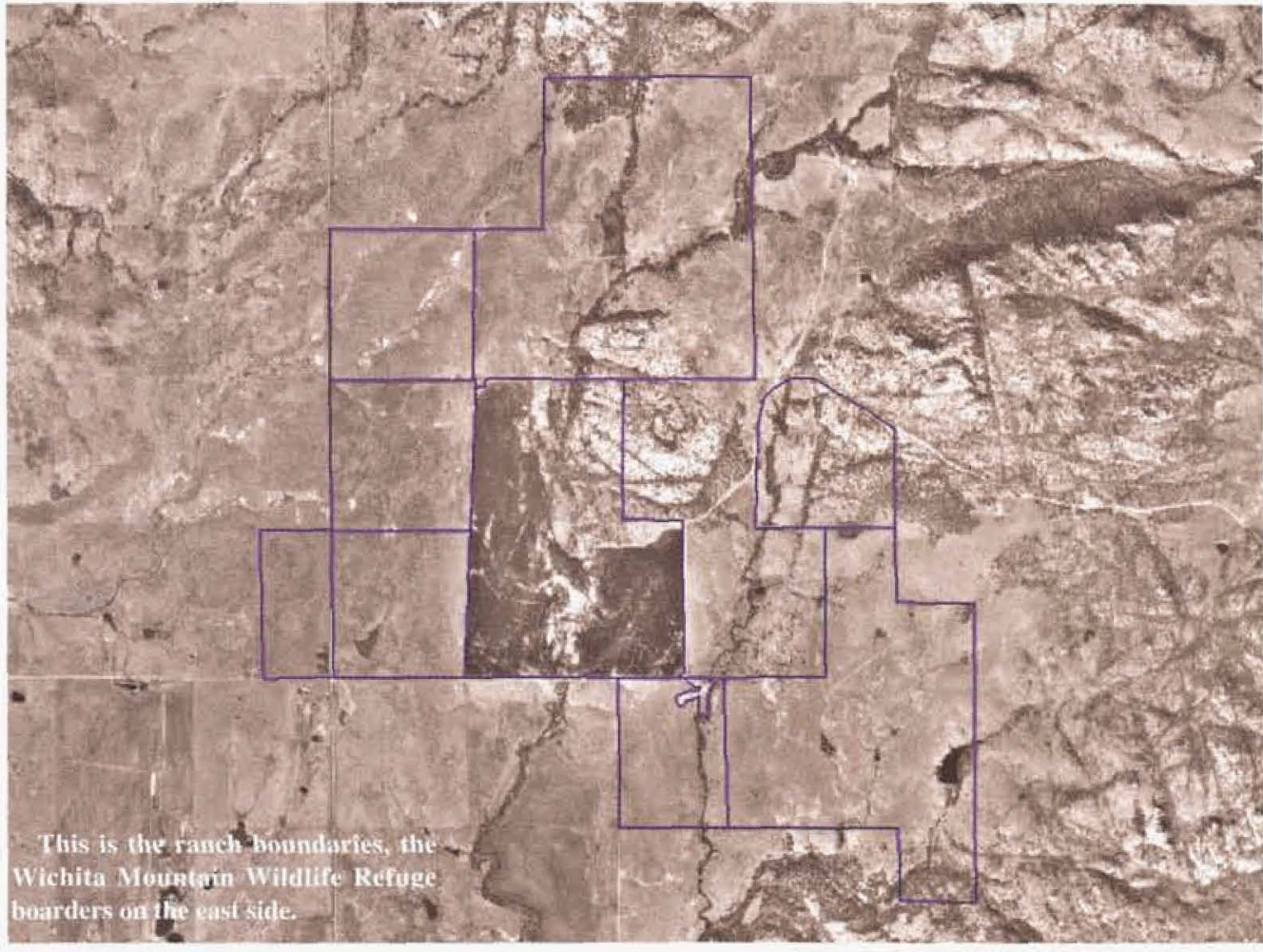

to a fresh paddock is key to winter grazing. "By holding them in smaller acreages, they aren't trampling on all of the forage all season long. Instead they are moving to fresh forage every few days. Even though it is dormant and there may not be much there, there is some nutrition and you are more efficient at utilizing it. We do this all winter long, and in March we're still moving to fresh paddocks where the grass isn't stale or trampled on," John says.

As the grass greens up and offers more nutrients in early April, the supplementation program ends and time spent grazing in a paddock is shortened to 1-3 days. When the forage is green, the animals initially rotate through the system quickly and then will pass through each of the paddocks again by mid- to late summer. This rotation system allows the animals to take advantage of the highest quality forage available and still allows adequate time for rest, say the Phelans.

"The aim is to just go around once in the dormant season, depending on the size and carrying capacity of the paddock," Phelan says. During the active growing season in spring and summer, we'll typically pass through the paddocks twice if enough forage is available, he adds.

In late June or early July, when forage quality begins to decline, approximately $1 \mathrm{lb}$./day of protein is supplemented. Shipping usually begins with the largest steers in late July or early August. The lighter weight steers will be held on grass longer to allow for more gain. However, this is not a hard and steadfast rule. If drought conditions make it necessary, the Phelans will ship the cattle earlier to protect the range.
The entire ranch receives a rest from August through mid-November when they begin receiving cattle again. At the end of each grazing season, the Phelans always aim to leave some standing forage to protect the health and vigor of the plants, minimize soil loss and improve water quality in their streams.

By combining all of their animals into one herd, rotating them through their cell grazing system, and allowing for adequate rest periods, the Phelans have noticed several improvements including an increase in more desirable forage species such as big bluestem, Indiangrass, switchgrass, and little bluestem. This in turn has significantly decreased problems

caused by erosion and runoff.

They believe their high stock density and rapid rotation through pastures helps achieve uniform utilization of all plants and helps minimize problems with poisonous plants, since most problem plants are grazed before they reach their toxic stage. The rapid rotations and high stock densities help the livestock to be free of flies and also aids in better distribution and recycling of urine and manure. Finally, this system also allows plants to stay healthier and robust due to periodic grazing, rather than become decadent through infrequent use.

\section{Monitoring For Success}

Those improvements are primarily due to the Phelan's watchful eye on their pastures. In the fall of each year, forage estimates are made to determine the carrying capacity for the coming year, the steers are purchased accordingly. John usually purchases 300-400 head of light weight, medium frame cattle in late November and early December.

But, facing their fifth year of drought this year, the

There were two other nominees for this year's Excellence In Range Management Award. They included from the Arizona SRM Section the Anvil Ranch near Tucson, AZ, operated by Pat King and Mary Miller. And, from the Texas SRM Section the XXX Ranch operated by John "Chip" Merrill near Crowley, TX. 
Phelan's have continued to decrease their stocking rate. "We currently have 150 head turned out," John reports. They've reduced their numbers in hopes of maintaining their range in good condition despite the inadequate rainfall.

Still there are challenges. Like any grazing operation, the Phelan's do have weeds, but they don't turn to chemicals to solve the problem. "I don't feel I can afford to spray them," John says. Instead, his strategy is to try to figure out what they are doing to cause the weeds and if possible fix it. "We've seen a lot of weeds the past few years, just due to drought. I try to deal with them through my grazing strategy, and I believe I can," he says.

Last summer Phelan did spray about 150 acres of mesquite with Reclaim and Remedy and reports that he had excellent results. "It's extremely expensive (about $\$ 30 /$ acre), but it worked very well. I hope not to have to spray that area again for a minimum of 10 years, maybe even 15-20," he says.

To add efficiency to their grazing program, the Phelan's have also worked with NRCS as part of their fecal sampling project. The collection of these samples has helped them make more economical and timely decisions concerning the supplementation of their cattle, the quality of the grass and the movement of the cattle.

Most recently, the Phelan's are working to implement a long-term range monitoring program on their ranch. Phelan says he implemented the system because of the drought. "I became concerned about the land condition when it got dry. So I needed some way to determine what's happening on the land,

Last summer John established three monitoring sites with assistance from Charlie Orchard of Land EKG. The sites include photo points and transects. Of his newly- implemented monitoring system, John says, "I'm very excited about this. I see it as something my sons can use in the future as well." He recognizes the importance of protecting and cultivating his resources on a day to day basis as well as for the future of their operation.

John adds, "We're starting gradually with just three monitoring sites because we don't want to overload ourselves with information. But I do plan to establish more monitoring sites and keep up with this over the long-term."

Even with the monitoring system in place, Phelan says much of range monitoring is still simply having an eye for the grass. "I often step off an acre square and visually appraise it as to what that acre can support. It's trial and error."

John says much of the success of his grazing system hinges on what he calls the two R's: rest and residual. "Plants need adequate rest, and you need to leave some residual plant material at the end of each grazing season. Graziers seem to think that just because you rest the range, it will all come back. But I believe it's important to watch how close you graze that grass. That saying of take half and leave half still applies. Taking over half of the plant really does slow regrowth," he says.

\section{About The Award}

The Outstanding Rangeland Management Award will be presented annually by the Society for Range Management (SRM). The award honors exemplary rangeland management and recognizes the "best of the best" from among Section Excellence in Range Management winners.

The objective of the award is to demonstrate to the public and other range managers outstanding examples of management which result in long-term health of the range resource while providing efficient production of livestock, wood products, and water, as well as supporting wildlife, esthetic and other non-commodity values.

The international winner is selected from poster presentations representing the winners' operation given at the annual SRM meeting. For more information about nominating a range manager for 2003 please contact, Jack Vandervalk at vans@ telusplanet.net or Trina Curtis at Trina.Curtis@id.usda.gov.

In practicing what he preaches, Phelan really monitors how much standing residual forage remains as the stockers rotate through each paddock for the last time in late summer. "If I feel I'm taking too much, I either need to move the animals faster or have a lower stocking rate. I don't think it's a good idea to flog a pasture. This drought has gotten my attention. When it rains you can kind of mess up and your sins will be forgiven. But not when it's dry."

John refers to his system as "time controlled grazing," and says, "It all has to do with time - either time grazed or time rested." But he cautions that implementing such a system won't automatically increase carrying capacity.

"Grazing systems like this were first sold as offering the ability to 'double your stocking rate.' But that is not true, especially if it doesn't rain. My advice to producers is to leave their animal numbers alone, get their feet wet with a controlled grazing system and then start measuring forage and stock accordingly. The only way to increase stocking rate is if you're growing more forage than before," John says.

He adds, "Critics ask, if you can't guarantee an increase in stocking rate, then why spend all that money on crossfencing and implementing such a system? But to me it's more than a monetary pay. You are taking better care of your country. And, in the long-term you will be rewarded for that."

Perhaps most importantly, the Phelan's are committed to sharing that philosophy and their ranch with others. Their ranch has served as a showcase for many tour groups, and they offer recreational leases, primarily for hunting and fishing, in order for the public to enjoy their resources.

It is all of these attributes combined that make it evident that the Phelan's truly are outstanding grazing lands managers. 


\section{Will California's Landscapes Keep Working?}

\section{The potential of "working landscapes" for conservation of rangelands was the subject of a public forum. Would a forum like this be useful in your area?}

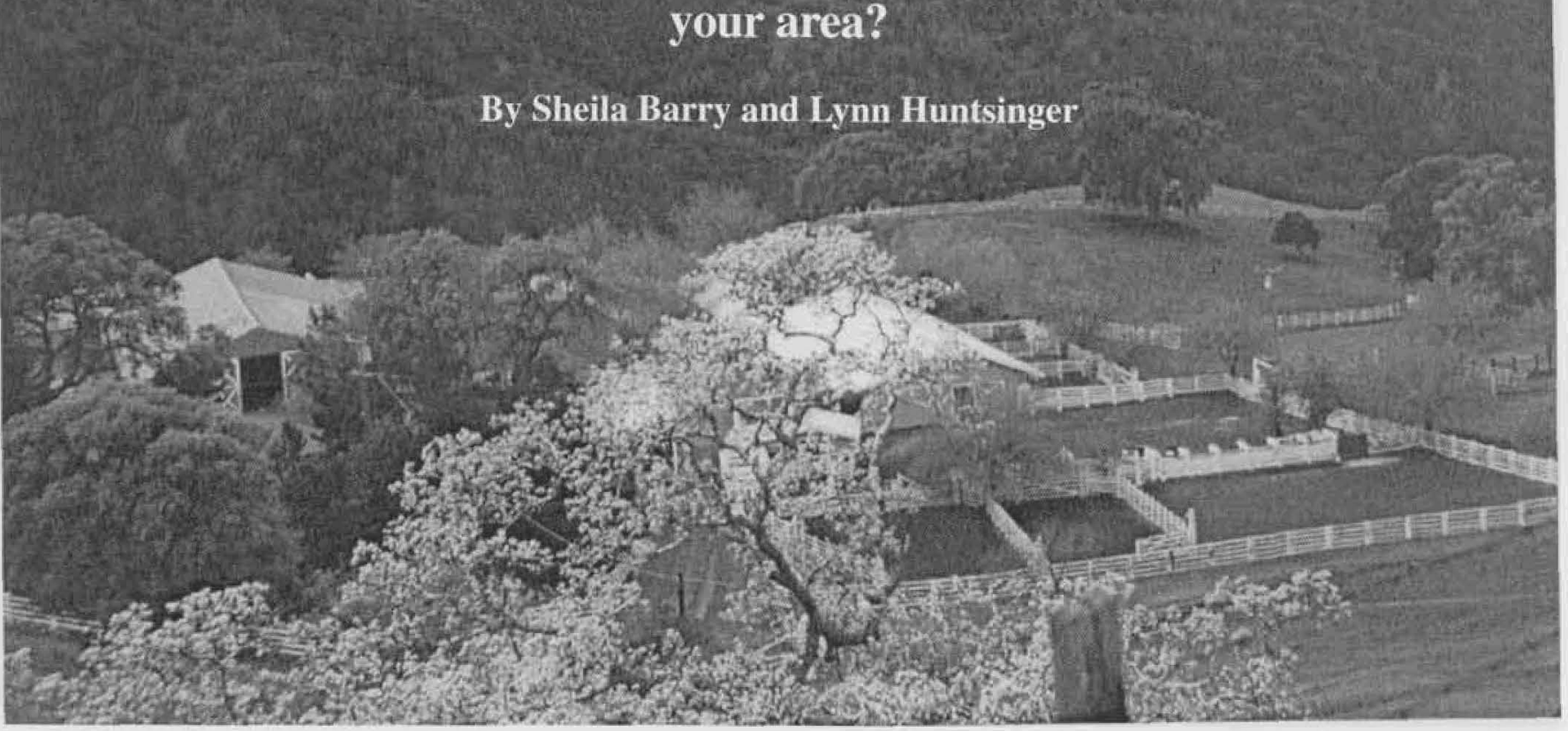

In California, oak woodland rangelands have a new "climax" state: ranchettes and housing developments. In fact. throughout the West urban encroachment threatens natural resource lands and rangeland landscapes,

Traditionally the alternative to uncontrolled land use change in areas with population growth has been to set aside land in parks or preserves. "Working landscapes" is a term coined to describe another alternative: deliberately maintaining land in farms and ranches.

In the fall of 2000 a forum was sponsored by University of California Cooperative Extension, the California Cattlemen's Association, The Nature Conservancy, and the California Rangeland Trust on "The Future and California's Working Landscapes." Community leaders, planners, educators, media representatives, and land managers were invited to learn and to share ideas about the role of working landscapes in open space management and protection in the oak woodlands and coastal foothills surrounding northern California's San Francisco Bay (Figure 1). The purpose was to begin a process of building support for working landscapes as a means of land conservation.

The existing programs of bonds, tax assessments, or grants to acquire land have proven to be increasingly expensive and impractical solutions to the problem of rangeland conversion. Land in the area is priced from several thousand to more than a million dollars per acre. Even if money is found to purchase a property, other costs continue to mount. Land management agencies lack management funds. Controlling noxious weeds, maintaining water developments, roads, and trails, and managing vegetation to reduce fire hazard requires personnel and funding. For example, the East Bay Regional Park District, which manages 92,000 acres in 59 regional parks, recreation areas, wilderness areas, shorelines, preserves, and land bank areas surrounding the San Francisco Bay, needs an annual budget of $\$ 80$ million to manage the land - a cost of $\$ 869 /$ acre.

Working landscapes, on the other hand, are productive lands that remain in private ownership. Income is realized from a sustainable natural resource industry, like ranching, but the open and undeveloped character of the landscape remains. Unfortunately, despite our long history of living off the land, much of the public seems to believe that being an observer is the best role for humans in a natural landscape. Yet it is likely that long-term conservation of rangelands and traditional rangeland uses will depend on public support for working landscapes.

Forum sponsors established a steering committee with broad representation, and the committee settled on a format that would allow maximum discussion and information sharing among the participants. Basically, three panels on pertinent topics would be followed by breakout groups to discuss and address questions about working landscapes. 


\section{The Forum Convenes}

After an introductory talk on the history and culture of ranching by Paul Starrs, author of Let the Cowboy Ride, the first panel of ranchers described the challenges they faced in coping with the current economic and regulatory situation, and the kinds of things they were doing to cope. Panelists had a chance to express their commitment to ranching as a way of life and to good stewardship.

Table. 1. What are the main difficulties in conserving open space?

The number in parentheses represents the average rank (1-4) among the groups. The lower the number, the greater the importance.

1. Escalating land values. (1.9) (most important difficulty) It is very expensive to purchase land for conservation.

For the private landowner, the financial incentives to develop are significantly greater than the economic return in trying to make a living off the land.

Local communities should share the burden of open space conservation.

2. Growing population pressure and urbanization. (2.2)

It is difficult to protect large tracts of land.

There is increasing competition for limited land resources.

3. Increasing costs to maintain and manage open space. (3.1) Land stewardship isn't compensated. Biological goals and values need to be integrated with economic viability for the landowners.

New economic opportunities are needed to support long-term viability of open space conservation.

4. Mutual lack of understanding and communication between landowners, public, government, agriculturalist, environmentalists, and developers. (3.3)

There can be an unwillingness to share information.

The impact of urbanization on agriculture is overlooked.

The ecological value of a working landscape is not often appreciated.

5. Conflicting and changing values regarding land use, including public policies versus private property rights. (3.5) (least important difficulty)

During the breakout session participants were asked, "What issues or problems do you see in conserving open space, including those you learned about this morning?" Breakout groups ranked problems from one as most important, to four as least important (Table 1).

The second panel showcased working ranches that are using grazing to achieve environmental objectives, and working with conservation organizations. During the following breakout session participants were asked, "How can working landscapes be used to conserve open space in the Bay Area?" (Table 2).

Dan Daggett, author of Beyond the Rangeland Conflict, spoke about working landscapes at lunch. Then the final panel discussed tools to sustain working landscapes, including conservation easements, niche marketing opportu-
Table. 2. How can working landscapes conserve Bay Area open space?

The number in parentheses represents the average rank (1-4) among the groups. The lower the number, the greater the importance.

1. Financial incentives for stewardship and to keep private ranchers on the land (not welfare for landowners). (2.1) (most important means)

Create value for good stewardship through direct payments, income or property tax breaks, or lower rent.

2. Community goal setting, visioning and planning. (2.8)

Build coalitions to support working landscapes.

3. Promote multiple-use on existing open space, i.e. recreation, grazing, watershed,wildlife habitat to increase economic viability and long-term sustainability. (3.1)

4. Place lands in "permanent protection," such as conservation easements or public ownership. (3.1)

5. Develop and implement regional,watershed-based plans to identify and conserve important open space. (3.1)

6. Community education on local working landscapes. (3.3)

Highlight successful working landscape examples.

Hands-on learning through field trips

Public meetings and workshops

7. Increase marketing opportunities for products from working landscapes, i.e. change current regulations to allow for direct marketing of meat, market locally-produced products. (3.6)

8. Reform land use policy, i.e. urban limit boundaries, zoning of open space subject to populace vote, minimum parcel size, subdivision controls. (3.7)

9. Include owners and managers of working landscapes to guide and inform local resource use issues. (3.8)

10. Encourage people who have an investment/connection to the land to continue wise stewardship. (3.9)

Make it easier for farmers and ranchers to pass their land to the next generation.

11. Promote and conduct collaborative research, i.e. ecological relationships, marketing, grazing and water quality impacts. (3.9) (least important means)

nities for ranchers, and partnerships. Participants were asked to brainstorm strategies to educate the public on working landscapes (Table 3).

\section{Who Came And What Did They Learn?}

The 125 people attending the Forum were surveyed before and after the meeting. We wanted to find out what kinds of people came, what they learned from the forum, and how to make improvements in future forums. Participants were diverse, with good representation from conservation groups, private business, and resource professionals (Table 4). The largest group was local and state government conservation or natural resource professionals.

Before and after surveys were used to evaluate the impact of the forum on the participant's perception of working 


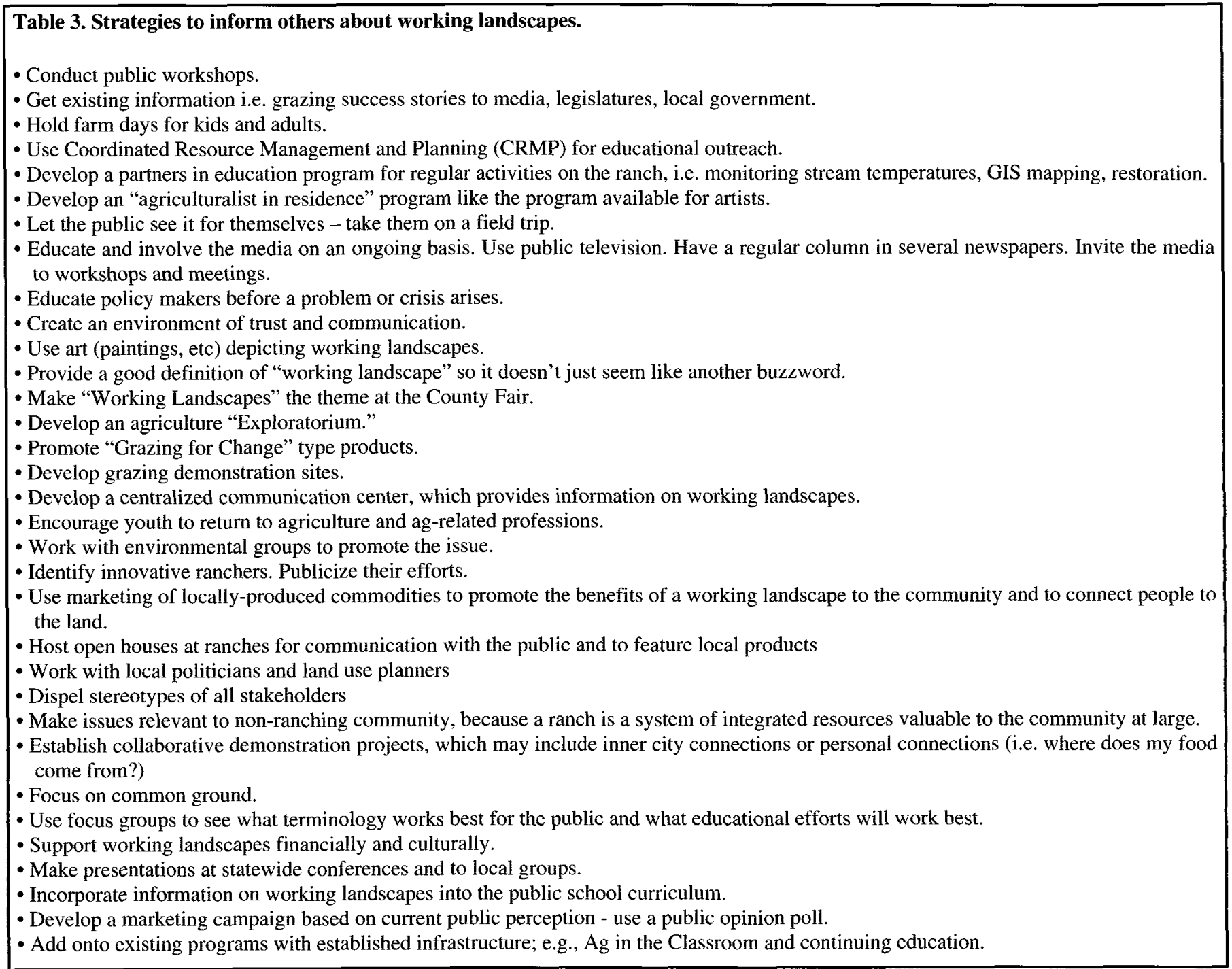

landscapes. Eleven questions were asked and evaluated. Responses to seven of them did not change significantly as a result of the forum (Table 5).

There was significant change during the forum in response to four of the questions (Table 6). The number of participants who were familiar with the concept of "work-

\begin{tabular}{|lc|}
\hline Table 4. Occupations of forum participants & \\
Extension or other advisory service & $11 \%$ \\
\hline Rancher or Farmer & $12 \%$ \\
\hline $\begin{array}{l}\text { Local or state govt. natural resource/conservation } \\
\text { professional }\end{array}$ & $23 \%$ \\
\hline Federal natural resource/conservation professional & $7 \%$ \\
\hline Municipal or regional utility or water district & $4 \%$ \\
\hline $\begin{array}{l}\text { Land Trust or Conservation (non-governmental } \\
\text { organization) NGO }\end{array}$ & $9 \%$ \\
\hline Other private organization or business & $18 \%$ \\
\hline University faculty and students & $14 \%$ \\
\hline
\end{tabular}

ing landscape" increased from $65 \%$ to $96 \%$ during the conference. The $8 \%$ of respondents who knew nothing at all about the concept initially, knew at least something about it by the end.

Before the conference $51 \%$ of respondents felt that maintaining a viable ranching community could be a somewhat to very successful way to conserve wildlife habitat and landscape in the Bay Area. Afterwards, that changed to $81 \%$ (Table 6). After the forum, participants believing that ranching had a long term future in the Bay Area increased also, from $42 \%$ to $64 \%$. Interestingly, the number thinking it was "very likely" that ranching had a long term future declined from $10 \%$ to $6 \%$, showing that some participants had become more familiar with the difficulties facing the ranching community.

Before the forum, $82 \%$ of respondents felt that conservation easements could be a somewhat to very successful way to conserve wildlife habitat and landscape in the Bay area. Afterwards, that changed to $96 \%$, with the greatest increase in those who thought it could be a "very successful" method. 
Table 5. Questionnaire responses that did not change significantly during the forum (percentages rounded).

Indicate how successful you feel each of the following strategies can be for wildlife habitat and landscape conservation in the Bay Area (circle one for each strategy):

\begin{tabular}{|c|c|c|c|c|}
\hline Land acquisition by the public & $\begin{array}{c}\text { Not at all } \\
\text { Successful } \\
8 \%\end{array}$ & $\begin{array}{c}\text { Possibly } \\
\text { Successful } \\
23 \%\end{array}$ & $\begin{array}{c}\text { Somewhat } \\
\text { Successful } \\
37 \%\end{array}$ & $\begin{array}{c}\text { Very } \\
\text { Successful } \\
33 \%\end{array}$ \\
\hline Land acquisition by private conservation organizations & $\begin{array}{c}\text { Not at all } \\
\text { Successful } \\
4 \%\end{array}$ & $\begin{array}{c}\text { Possibly } \\
\text { Successful } \\
14 \%\end{array}$ & $\begin{array}{c}\text { Somewhat } \\
\text { Successful } \\
47 \%\end{array}$ & $\begin{array}{c}\text { Very } \\
\text { Successful } \\
35 \%\end{array}$ \\
\hline Strong land use planning & $\begin{array}{c}\text { Not at all } \\
\text { Successful } \\
4 \% \\
\end{array}$ & $\begin{array}{c}\text { Possibly } \\
\text { Successful } \\
31 \%\end{array}$ & $\begin{array}{c}\text { Somewhat } \\
\text { Successful } \\
27 \%\end{array}$ & $\begin{array}{c}\text { Very } \\
\text { Successful } \\
38 \%\end{array}$ \\
\hline Unrestricted marketing of land & $\begin{array}{c}\text { Not at all } \\
\text { Successful } \\
81 \%\end{array}$ & $\begin{array}{c}\text { Possibly } \\
\text { Successful } \\
15 \%\end{array}$ & $\begin{array}{c}\text { Somewhat } \\
\text { Successful } \\
0 \%\end{array}$ & $\begin{array}{c}\text { Very } \\
\text { Successful } \\
4 \%\end{array}$ \\
\hline Stronger governmental regulations for private land management & $\begin{array}{c}\text { Not at all } \\
\text { Successful } \\
19 \%\end{array}$ & $\begin{array}{c}\text { Possibly } \\
\text { Successful } \\
63 \%\end{array}$ & $\begin{array}{c}\text { Somewhat } \\
\text { Successful } \\
17 \%\end{array}$ & $\begin{array}{c}\text { Very } \\
\text { Successful } \\
2 \%\end{array}$ \\
\hline
\end{tabular}

Please circle one response for each of the following questions:

\begin{tabular}{|l|c|c|c|c|}
\hline $\begin{array}{l}\text { c. Do you think that grazing is compatible with conservation goals } \\
\text { like protecting wildlife habitat or plant communities? }\end{array}$ & $\begin{array}{c}\text { Not at All } \\
\text { Compatible } \\
4 \%\end{array}$ & $\begin{array}{c}\text { A Little } \\
\text { Compatible } \\
9 \%\end{array}$ & $\begin{array}{c}\text { Somewhat } \\
\text { Compatible } \\
36 \%\end{array}$ & $\begin{array}{c}\text { Very } \\
\text { Compatible } \\
51 \%\end{array}$ \\
\hline $\begin{array}{l}\text { d. Do you think that grazing can be useful for reducing fire } \\
\text { hazard? }\end{array}$ & $\begin{array}{c}\text { Not at All } \\
\text { Useful } \\
4 \%\end{array}$ & $\begin{array}{c}\text { A Little } \\
\text { Useful } \\
16 \%\end{array}$ & $\begin{array}{c}\text { Somewhat } \\
\text { Useful } \\
12 \%\end{array}$ & $\begin{array}{c}\text { Very Useful } \\
67 \%\end{array}$ \\
\hline
\end{tabular}

Participants were also asked to comment on the conference, telling us what they learned that would be useful to them, and how we might improve this type of forum. We were pleased to find that responses were overwhelmingly positive. Some of the most useful things participants learned were how conservation organizations are working with ranchers, and about the possibilities of ranchers as environmental partners. Participants especially appreciated the discussion of concrete, ground-tested tools for increasing and protecting biodiversity in a working landscape, including grass banking, improved grazing management, and conservation easements. Participants wanted more tools, and a broad approach that went beyond ranching and across disciplines. Other kinds of working landscapes could be included, in the opinion of some. The participation of conservation groups was highly valued.

The forum got many of the participants thinking about incentives for private conservation, especially given the current economics of agriculture in California. Some commented that they felt much better informed about the barriers facing continued ranching. A couple of people were disappointed that the forum did not address public land management issues.

Most respondents valued the opportunity to network with others, and to find such a diverse group with a common interest in landscape conservation. One rancher commented that he or she learned the need for working and visiting with those who don't understand ranching or ranch land. Respondents stated that they came away with an increased desire to spend more time building community, and developing common goals with landowners and other community stakeholders. At future meetings, they want to see more and broader participation from a variety of environmental groups, Resource Conservation Districts, and government planners.

The next step, many agreed, was to get down to the nuts and bolts of how to accomplish specific conservation goals, and to develop policy actions that would help. One respondent would have liked more information about the amount and character of grazing in the Bay Area.

\section{Working Landscapes Will Require Working Together}

Participants came looking for ways to develop constructive compromise for land conservation. We believe this reflects the pool of invitees - most had some practical experience in land conservation, in one way or another, and were acquainted with its complexities. For future programs, participants want more broad participation, and more intense workshops on the specifics of the tools for encouraging land conservation on private lands.

The forum itself accomplished some important goals. People learned more about working landscapes, and gained an appreciation of both the problems and the opportunities 
Table 6. Responses changing significantly as a result of the forum (percentages rounded).

\begin{tabular}{|c|c|c|c|c|}
\hline Question: & $\begin{array}{l}\text { Before the } \\
\text { Forum }\end{array}$ & $\begin{array}{l}\text { After the } \\
\text { Forum }\end{array}$ & $\begin{array}{l}\text { Before the } \\
\text { Forum }\end{array}$ & $\begin{array}{l}\text { After the } \\
\text { Forum }\end{array}$ \\
\hline $\begin{array}{l}\text { How successful would maintaining a viable ranching community be } \\
\text { for wildlife conservation and landscape conservation in the } \\
\text { Bay Area? }\end{array}$ & $\begin{array}{c}\text { Somewhat } \\
\text { Successful } \\
\text { (BEFORE) } \\
\mathbf{2 5 \%} \\
\end{array}$ & $\begin{array}{c}\text { Somewhat } \\
\text { Successful } \\
\text { (AFTER) } \\
29 \% \\
\end{array}$ & $\begin{array}{c}\text { Very } \\
\text { Successful } \\
\text { (BEFORE) } \\
37 \% \\
\end{array}$ & $\begin{array}{c}\text { Very } \\
\text { Successful } \\
\text { (AFTER) } \\
\mathbf{5 2 \%}\end{array}$ \\
\hline $\begin{array}{l}\text { How successful would conservation easements be for wildlife } \\
\text { conservation and landscape conservation in the Bay Area? }\end{array}$ & $\begin{array}{c}\text { Somewhat } \\
\text { Successful } \\
\text { (BEFORE) } \\
44 \% \\
\end{array}$ & $\begin{array}{c}\text { Somewhat } \\
\text { Successful } \\
\text { (AFTER) } \\
31 \% \\
\end{array}$ & $\begin{array}{c}\text { Very } \\
\text { Successful } \\
\text { (BEFORE) } \\
38 \% \\
\end{array}$ & $\begin{array}{c}\text { Very } \\
\text { Successful } \\
\text { (AFTER) } \\
65 \% \\
\end{array}$ \\
\hline How familiar are you with the concept of a working landscape? & $\begin{array}{c}\text { Somewhat } \\
\text { Familiar } \\
\text { (BEFORE) } \\
35 \% \\
\end{array}$ & $\begin{array}{c}\text { Somewhat } \\
\text { Familiar } \\
\text { (AFTER) } \\
33 \%\end{array}$ & $\begin{array}{c}\text { Very } \\
\text { Familiar } \\
\text { (BEFORE) } \\
\mathbf{3 0 \%}\end{array}$ & $\begin{array}{c}\text { Very } \\
\text { Familiar } \\
\text { (AFTER) } \\
63 \%\end{array}$ \\
\hline $\begin{array}{l}\text { How likely do you think it is that ranching has long term future in } \\
\text { the Bay Area? }\end{array}$ & $\begin{array}{c}\text { Somewhat } \\
\text { Likely } \\
\text { (BEFORE) } \\
31 \% \\
\end{array}$ & $\begin{array}{c}\text { Somewhat } \\
\text { Likely } \\
\text { (AFTER) } \\
\mathbf{5 8 \%}\end{array}$ & $\begin{array}{l}\text { Very Likely } \\
\text { (BEFORE) } \\
10 \%\end{array}$ & $\begin{array}{c}\text { Very } \\
\text { Likely } \\
\text { (AFTER) } \\
6 \%\end{array}$ \\
\hline
\end{tabular}

in using private rangeland management as a means of conserving open land. We believe that we did increase support for the multiple-use agriculture-based working landscape concept - participants were more favorably inclined toward consideration of the welfare of the ranching community in developing land conservation programs at the end of the meeting. Further, the networking that many participants mentioned as a valuable part of the concept should further extend and maintain this support. Working to maintain contact with participants and to continue to share information with them will be important.

The problems facing California are not unique. Our experience leads us to believe that the concept of working landscape can facilitate communication among diverse groups that share a common interest in land conservation and good stewardship. Ranchers and conservationists need to work together for incentive-based conservation strategies to work, and a setting that allows for discussion and mutual learning is needed. Community forums such as this can:
1. increase understanding of working landscapes (barriers as well as opportunities);

2. catalyze local/regional action;

3. broaden on-going information sharing, particularly among government agencies and non-governmental organizations;

4. increase the role of the ranching community and other agriculturalist and landowners in developing land conservation programs; and

5. demonstrate broad stakeholder commitment to working landscapes.

\section{About the authors:}

Sheila Barry and Lynn Huntsinger, Bay Area Natural Resources Advisor, UCCE Santa Clara County, 700 Empey Way, San Jose, California 95128, and Associate Professor. Department of Environmental Science Policy, and Management, University of California, Berkeley California 94720.

For more information, contact Sheila Barry, UCCE Santa

Clara, 700 Empey Way, San Jose, CA 95128.

email: sbarry@ucdavis.edu Fax: 408-298-5160 


\section{Cows \& Cash}

\section{Trends On Nevada's Public Lands}

\section{By Rob Pearce, Don Henderson, Sandy Jonkey, Gabe Fogarty, and Tim Dardin}

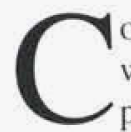
ontroversy has plagued public land grazing in the western United States for decades. Those supporting public land grazing are as adamant about the propriety of their views as are their opponents, who see grazing of federal lands as an adverse and often unnecessary use of western public land. The argument intensifies with each passing year. The debate itself is plagued with problems; especially the emotional intensity that surrounds those involved with the discussion. Individuals on both sides of the fence often cloud their views and opinions in a fog of emotion, rather than scientific or research supported information.

Opponents of public land grazing often say it as has little impact to local economies and the livestock industry as a whole. However, the importance of grazing management decisions, and the ensuing effects to rural Nevada economies, should not be trivialized. This article contains definitive results illustrating the impact that federal land grazing decisions may have on rural economies. As outlined below, decisions to reduce or increase grazing on federal lands do have implications for the rural and state economies. This article is a summary of a larger and more detailed report on Nevada's federal land grazing history primarily from 1980 through 1999.

The consulting firm Resource Concepts, Inc. (RCI), produced three reports that addressed grazing history for about 1/3 of Nevada federal lands up to 1995 . Those three reports were summarized and presented in a 1999 edition of Rangelands. During the process of producing the three reports, RCI collected Bureau of Land Management (BLM) grazing data for the entire state. Therefore, a Nevada Grazing Statistics (NGS) database existed that contained nearly complete Bureau of Land Management grazing records from adjudication through 1999 and some United
States Forest Service (USFS) grazing records. No other Federal land data had been compiled for the state.

The intent of this project, and the ensuing report, was to add credence and reliable information to the discussion of public land grazing. Several important aspects of the public land debate, at least for Nevada, are presented in the following pages. These include: available historical permitted numbers of livestock on Nevada Federal lands, mapping for agency boundaries of federal land grazing areas, and economic impacts to ranching and rural economies from federal grazing over the last 19 years. The study includes documented grazing histories and economic grazing impacts from federally administered lands within the state of Nevada for the period of 1980 through 1999. The lands reviewed include Bureau of Land Management (BLM), United States Forest Service (USFS), United States Fish and Wildlife Service (USFWS), Bureau of Reclamation (BOR), and National Park Service (NPS) administered lands Nevada lands (Figure 1).

This project was a cooperative venture between the Nevada Department of Agriculture and the Nevada Association of Counties (NACO). The project was contracted to Resource Concepts, Inc., who in cooperation with the University of Nevada, Reno, University Center for Economic Development, updated the existing database, gathered data for the remaining federal lands not covered in the database, and analyzed the public land grazing data on a statewide basis.

Recognizing the importance of public land grazing to the agricultural sector and to rural Nevada communities and economies, the Nevada Legislature appropriated $\$ 80,000$ to the Department of Agriculture during the 1999 legislative session. The purpose of this appropriation was for the de-

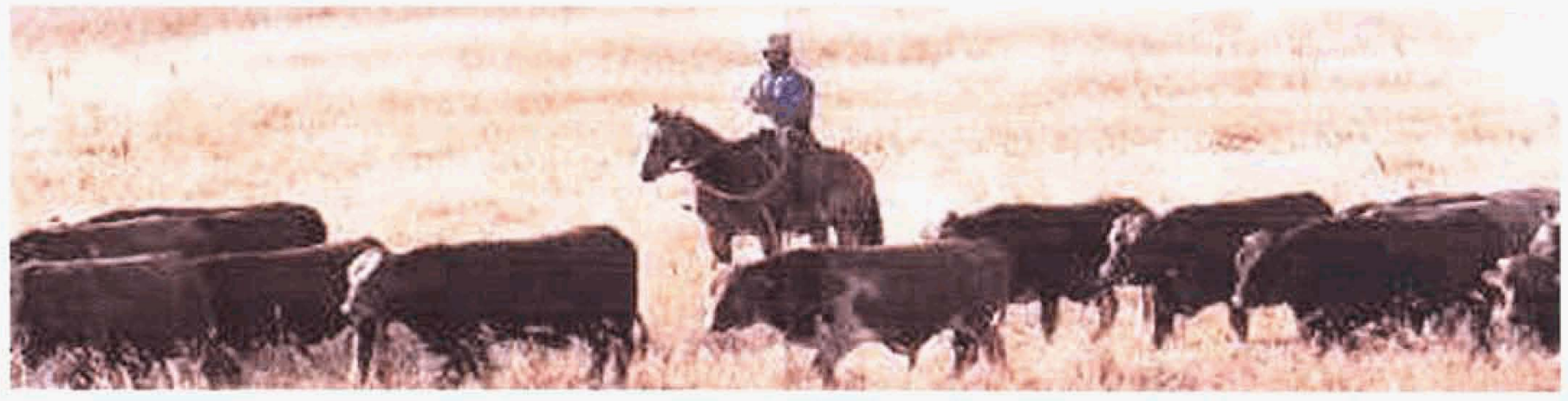




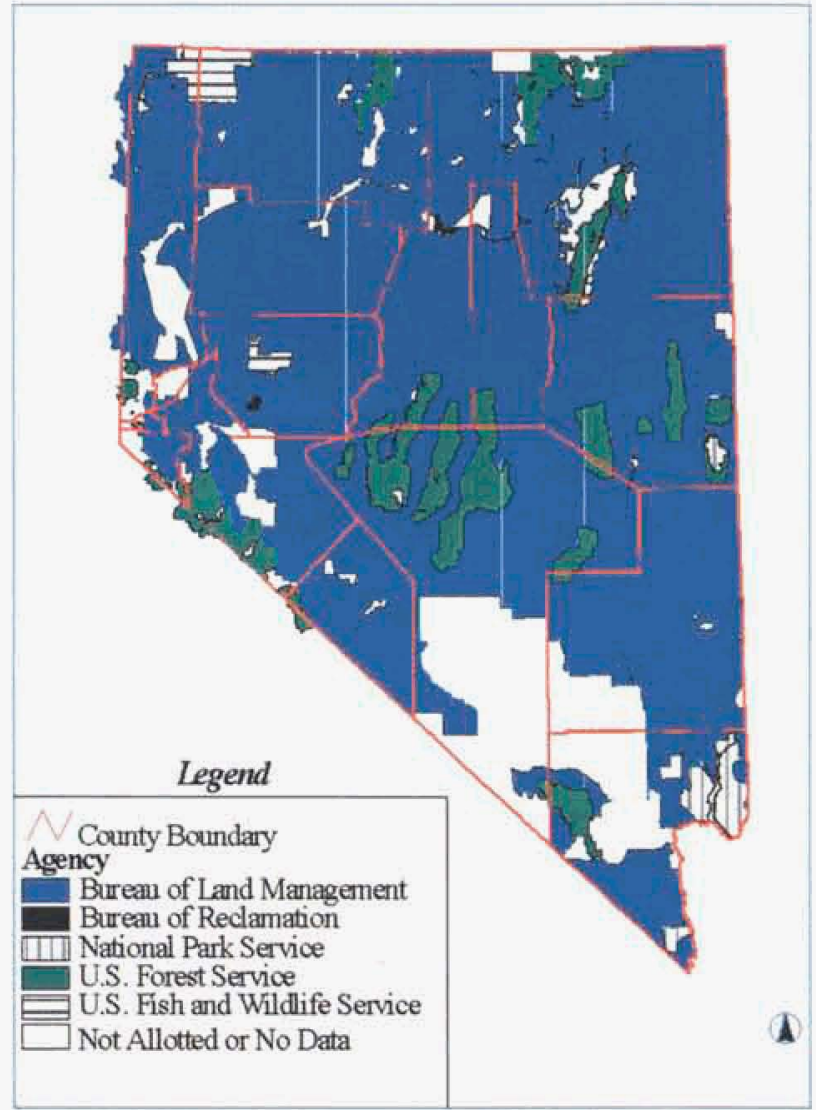

Figure 1. Jurisdictional boundary map for federal lands in Nevada. Jurisdictional boundaries included on the map are Bureau of Reclamation (BOR), W.S. Fish and Wildlife Service (USFWS), National Park Service (NPS), U.S. Forest Service (USFS), and Bureau of Land Management (BLM).

partment to retain the necessary assistance to: 1 ) document public land grazing levels in Nevada over time to determine trends; and, 2) provide an estimate of the economic effects to rural communities and economies resulting from the documented trends.

\section{What Information Was Collected?}

Beginning in January 2000 Nevada grazing data were gathered for Bureau of Land Management (BLM), U.S. Forest Service (USFS), Bureau of Reclamation (BOR), United States Fish and Wildlife Service (USFWS), and National Park Service (NPS) managed lands (Figure 1). Data collected included the following for each agency: permit or allotment name, permit or allotment number, permittee or lessee name, number of Animal-Unit-Months, and associated maps. Data gleaned for BLM allotments included records for adjudication, 1980, 1995, and 1999. For all other Federal lands grazing data were obtained for 1980, 1995, and 1999. Economic Analysis was conducted for all Nevada Federal lands for 1980 through 1999. Trend data in this paper are also for the 1980-1999 period.

During the course of this project it became apparent that definitions to describe similar concepts varied among Bureau of Land Management Field Offices and also among other agencies. The following definitions are offered so the reader will better understand each term and their intent throughout this paper.

* AUMs = Animal-Unit-Month, one mature (1000 pound) cow or the equivalent based upon average daily forage consumption of 790 pounds of dry matter per month. For a complete discussion of AUM definitions and variations among agencies refer to Pearce et al. 1999 and NDA 2001 listed in the additional readings.

* Permitted Use (Active Use, Permitted Preference, Active Preference): Bureau of Land Management and U.S. Forest Service term to denote the maximum allowable AUMs permitted to a permittee. The Bureau of Land Management definition is as follows: "The maximum amount of livestock grazing allowed. Permitted Use is expressed in AUMs authorized under a term permit or lease for an individual permittee/lessee for and individual public land allotment. This level does not include 'adjudicated suspended non-use,' nor does it include authorizations issued as non-renewable, or authorizations authorized under an exchange of use agreement."

* Authorized Use: A Bureau of Land Management term to designate the number of Animal-Unit-Months paid for by a permittee.

* Actual Use: A Bureau of Land Management and U.S. Forest Service term to denote the number of AUMs grazing on the permit, i.e., the actual physical bodies of livestock on the land.

* Historical Suspended AUMs: A Bureau of Land Management term to describe the number of AUMs present, and above permitted AUMs at the pre adjudication period and cancelled through administrative decision.

Early in 2000, Nevada Association of Counties submitted letters to the Bureau of Land Management, HumboldtToiyabe National Forest, Bureau of Reclamation, U.S. Fish and Wildlife Service, Great Basin National Park, and Lake Mead National Recreation Area describing the project, listing what information was being requested, and seeking cooperation in data collection and compiling the required grazing information.

The Bureau of Land management staff requested that once the accumulated data were entered into the Nevada Grazing Statistics database that a hardcopy be provided for verification. The verification with Bureau of Land Management and other federal agencies was also required as part of the contract with Nevada Association of Counties. The Bureau of Land Management and U.S. Forest Service were provided a draft version of all allotment records for verification. During November and December Resource Concepts, Inc. received corrected Bureau of Land Management allotment data from most of 
the Bureau of Land Management Field Offices and corrected data for the U.S. Forest Service.

All grazing data collected for this project was input into a Microsoft Access Database (NGS database). Allotment mapping was also collected during the project and is included in Nevada Department of Agriculture (NDA) 2001 document and in a GIS database. The Access database is linked with an ArcView GIS database containing allotment mapping.

The economic analysis portion of the project evaluated the period from 1980 through 1999. The 1980 starting year for economic analysis was selected because that was the first year complete data could be obtained from U.S: Forest Service records in Nevada. The 1995 data are included in this study because that is the year the three previous Nevada Grazing Statistics reports were used as the final reporting year.

\section{Reasons For AUM Reductions}

Included in the NGS database are "data fields (areas to input data)" for notes and reasons for changes in AUMs between 1980 and 1995, and between 1995 and 1999. Every effort was made during the data collection process to compile reasons for every Animal-Unit-Month change. However, information was not always available.

Ten broad categories were selected to represent major reasons for changes in AUMs. Those categories include: boundary changes, change of class of livestock, Final Multiple Use Decision (FMUD - usually resource related), Forest Service Enhancement Act, permit violations, resource related (e.g., monitoring data suggested that too many livestock were utilizing the allotment, or other resource type decisions), transfer of ownership, other, unknown (the record was reviewed but no reason for change could be found), and no change.

The numbers provided in each reason section in Tables 1-2 represent a net gain or loss. Each category may have had losses and gains. What is reported in each table is the overall loss or gain.

\begin{tabular}{|lcc|}
\hline $\begin{array}{l}\text { Table 1. Bureau of Land Management Animal-Unit-Month Losses } \\
\text { (AUM) in Nevada from 1980-1999 by reason. }\end{array}$ \\
\hline \hline Reason & AUMs & $\begin{array}{c}\text { Percent of } \\
\text { Total Change }\end{array}$ \\
\hline No reason given in the database & $\mathbf{1 6 4 , 0 8 7}$ & 44 \\
Resource Related & 89,619 & 24 \\
Permit Violation & 35,210 & 9 \\
Change in Class of Livestock & 34,179 & 9 \\
Forest Service Enhancement Act & 19,189 & 5 \\
Transfer of Ownership & 11,863 & 3 \\
Final Multiple Use Decision & 10,485 & 3 \\
Boundary Change & 9,413 & 3 \\
Total & 374,045 & 100 \\
\hline \multicolumn{2}{l}{} \\
\hline
\end{tabular}

Table 2. United States Forest Service Animal-Unit-Month (AUM) changes in Nevada from 1980-1999 by reason. (numbers in parenthesis represent a gain).

\begin{tabular}{lrc}
\hline \hline Reason & AUMs & $\begin{array}{c}\text { Percent of } \\
\text { Total Change }\end{array}$ \\
\hline Boundary Change & 41,517 & 48 \\
No reason given in the database & 25,230 & 28 \\
Resource Related & 19,719 & 23 \\
Forest Service Enhancement Act & $(17,605)$ & $(20)$ \\
Permit Violation & 13,672 & 16 \\
Transfer of Ownership & 5,716 & 7 \\
Change of Class of Livestock & $(1,960)$ & $(2)$ \\
Total & 86,289 & 100 \\
\hline
\end{tabular}

Reasons are presented for $56 \%$ Bureau of Land Management (BLM) AUM reductions that occurred in Nevada from 1980-1999, (Table 1). This leaves $44 \%$ of the BLM AUM reductions without explanation for a change. Absent explanations for the AUM changes can be attributed to several factors. Among them, BLM records did not contain reasons, or reasons were not entered into the original database, prior to this phase of the project.

Three categories account for $87 \%$ of U.S. Forest Service 86,289 AUM reductions in Nevada (Table 2). The three categories are boundary changes, resource related, and permit violations.

The resource related and permit violation categories are the two most important categories for AUMs changes in the Bureau of Land Management and U.S. Forest Service data. Those two categories alone account for over $1 / 3$ of the reductions in AUMs on Bureau of Land Management and U.S. Forest Service lands.

\section{Economic Impacts}

The University of Nevada, Reno, University Center for Economic Development conducted the economic analysis for this project. Potential estimated economic impacts to rural Nevada resulting from changes in livestock AUMs were calculated using the Micro IMPLAN model developed by the U.S. Forest Service. The model estimates sectoral and regional impacts of alternative management scenarios. For a thorough discussion and explanation of the Model review the U.S. Forest Service IMPLAN manual authored by Alward and the Nevada Department of Agriculture report written in 2001. The IMPLAN model has been further revised by the University of Minnesota to accommodate analyses of other impacts, such as livestock number fluctuations. The period of economic analysis for all Federal lands in Nevada is from 1980-1999.

The following economic and AUM grazing allocation changes occurred in Nevada from 1980-1999 (economic values assume that if each AUM lost was active then the values presented represent the losses depicted) (Figure 2). 


\section{Grazing History - Nevada Federal Lands}

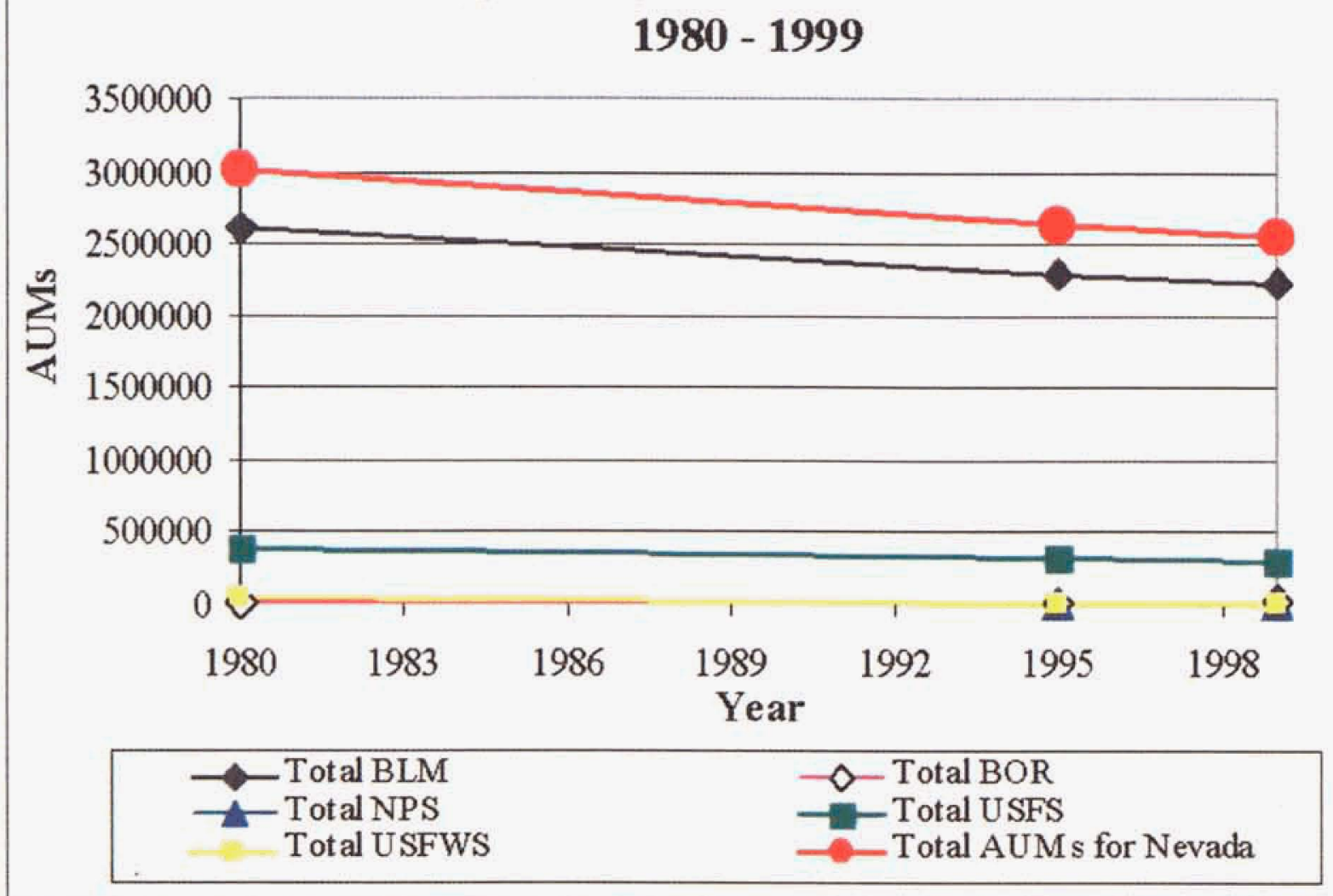

Figure 2. Grazing summary of AUMs for federal lands in Nevada from 1980-1999. Federal lands histories include Bureau of Reclamation (BOR), U.S. Fish and Wildlife Service (USFWS), National Park Service (NPS), U.S. Forest Service (USFS), Bureau of Land Management (BLM), and all federal land grazing AUM trends combined.

* Combined federal land AUMs lost in the state of Nevada from 1980 through 1999 were 473,553 (16\%) with a corresponding estimated loss of over $\$ 24,000,000$ to Nevada, and an estimated loss of nearly 12 million dollars to Nevada's livestock industry.

* Impacts to Bureau of Land Management lands included a loss of 374,045 (15\%) permitted Animal-Unit-Months (AUMs). These losses in AUMs resulted in an estimated financial loss of nearly $\$ 20,000,000$ to the state of Nevada, with a corresponding estimated loss of $\$ 9,000,000$ to Nevada's livestock industry for the 19-year period evaluated in this study.

* U.S. Forest Service administered lands realized an estimated loss of 86,289 AUMs ( $23 \%$ ) and an estimated economic loss of $\$ 4,500,000$ to Nevada, with a $\$ 2,100,000$ negative estimated impact to Nevada's livestock industry.

*A loss of 25,176 AUMs (78\%) were realized on U.S. Fish and Wildlife Service administered lands from 1980-1999 with $\$ 1,300,000$ estimated loss to Nevada's economy and $\$ 600,000$ estimated losses to the Nevada livestock industry.

* Bureau of Reclamation lands saw an increase of 10,218 AUMs and a resultant $\$ 500,000$ estimated positive im- pact to Nevada's economy and $\$ 250,000$ to Nevada's livestock industry.

* National Park Service lands lost 313 AUMs with a corresponding estimated loss to the Nevada livestock industry of $\$ 8,000$ and a $\$ 16,000$ loss to Nevada's economy as a whole.

With the exception of Bureau of Reclamation lands, changes in Animal-Unit-Months (AUMs) throughout the state were generally a downward trend during the 1980 to 1999 period. These changes can be attributed to shifts in administrative policies, climatic factors, livestock prices, resource conditions, competition with wildlife and feral horses, and a host of other factors.

Bureau of Land Management AUM reductions since adjudication (the period from about 1960 through 1999) amount to a 468,114 AUM decrease. Prior to adjudication there were an additional 419,755 historical suspended AUMs. Therefore, during the tenure of Bureau of Land Management land management in Nevada there have been approximately 890,000 AUMs removed from Nevada Bureau of Land Management rangelands. The historical suspended AUMs represent a reduction in AUMs prior to adjudication, but not analyzed in this study. 
The analysis provided in this study has shown that changes in the numbers of livestock grazing on Nevada public lands impact Nevada's economy, particularly the fragile economy of rural Nevada.

\section{Collaboration And Cooperation Needed}

The downward trend of livestock grazing experienced on Nevada public lands over the last 19 years is illustrated throughout this article. This trend is likely a result of many factors, including, environmental, ecological, sociological, and administrative policy.

There are continual pressures and challenges facing livestock grazing in Nevada. However, it is important to realize that grazing of rangelands is a manageable activity. Grazing is the controlled harvest of a sustainable natural resource. The practice of grazing rangelands is a good example of low-input agriculture, requiring little fossil fuel when compared to many other forms of agriculture. Livestock are turned out to graze, rotated from one grazing unit to another, or herded through an area while harvesting forage. Grazing animals convert natural and cultivated forage into red meat protein

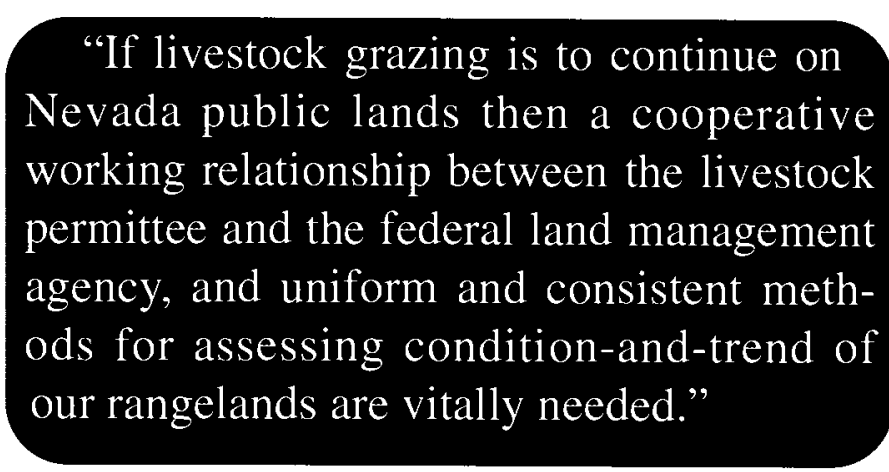

* A change in public attitude toward grazing

* A reluctance, or inability, of federal agencies to invest in rangeland improvement projects

* A distrust, and often poor working relationship, among federal land administrators, permittees, and the general public.

* Region wide resource condition decisions rather than site specific evaluations

Nevada public land grazing issues that permittees face today are often localized and related to livestock distribution problems, which can be resolved by site specific planning, as opposed to further livestock reductions. In the past, federal agencies have tended toward prescriptive grazing standards, regional or landscape based planning processes, and penalty driven program administration. These approaches offer little incentive or opportunity for private investment for site specific management solutions to address specific grazing issues. If continued, this approach will likely result in further declines in public land grazing and further adverse economic effects to the Nevada livestock industry, dependent rural economies, and local governments.

Collaboration and cooperation among agency staff, perfor human consumption, along with other products. When viable, the livestock industry contributes to the economic well being of Nevada, the tax base of the state, and also helps to maintain a much needed diversified economy.

Resource managers have an opportunity to work cooperatively under present state and federal agency leadership to better plan and administer the management of Nevada's public land resources. If livestock grazing is to continue on Nevada public lands then a cooperative working relationship between the livestock permittee and the federal land management agency, and uniform and consistent methods for assessing condition-and-trend of our rangelands are vitally needed.

Our study provided a description of Animal-Unit-Month (AUM) trends in Nevada, gave explanations for the changes (when known), and described estimated economic impacts to Nevada's economy. It is apparent from our study that many factors influence AUM changes on public lands in Nevada. Results from this study indicated that permit violations and resource protection were the primary reasons for AUM reductions in Nevada. However, in our experience, other factors have also contributed to this decline in grazing in Nevada, that are not evident in the data. We feel additional forces driving the decline in livestock grazing have been: mittees, the scientific community, and the general public will help resolve resource concerns. All groups and individuals involved with public land grazing have responsibilities to the public and to the natural resource. Federal agency personnel have a responsibility to provide resource management plans, provide objectives, and conduct monitoring based on sound scientific reasoning and an understanding of the needs of all that use public lands. Public land livestock operators are obligated to manage their operations with respect and concern for resources, and to base land management decisions on established rangeland management techniques.

Sound resource management decisions based on site specific resource conditions, combined with a collaborative working relationship between the responsible land management agency and the livestock permittee, will provide the best opportunity for maintaining an economically viable livestock industry in Nevada.

About the authors: Rob Pearce* is a Plant Ecologist with Pacifica Services, Inc, Bishop, CA; Sandy Jonkey, and Gabe Fogarty are, Senior Range Technicians with Resource Concepts, Inc., Carson City, Nevada; Don Henderson is a Deputy Director, Nevada Department of Agriculture, Carson City, Nevada; Tim Dardin is Research Analyst, University of Nevada, Reno, University Center for Economic Development.

* At the time of this research Robert Pearce was a Rangeland Ecologist at Resource Concepts, Inc. Carson City, Nevada. 


\section{How BLM Came About}

The majority of public land grazing in Nevada occurs on Bureau of Land Management and U.S. Forest Service administered lands. While the U.S. Fish and Wildlife Service, National Park Service, Bureau of Reclamation, and other federal agencies do permit grazing, their contribution to total federal land grazing is a small percentage of the total.

Grazing on federal lands has gone through many stages over the past two centuries, and changes continue to occur to this day. Early explorers and settlers homesteaded the most fertile and well irrigated lands. In the mid and late 1800's ranchers grazed livestock on the federal lands with little intervention or regulation. However, with increasing competition and conflict among federal land users, and as environmental stewardship awareness increased, it became necessary to regulate federal land grazing. Prior to 1905 , the Department of Interior's General Land Office (GLO) managed forest reserves (part of which became the U.S. Forest Service lands) and federal lands (those that are now Bureau of Land Management administered). In Rowley's book on the history of the U.S. Forest Service's grazing history he stated that in 1894, while still under GLO control, the "driving, feeding, grazing, pasturing, or herding of cattle, sheep, or other livestock" was prohibited within forest reserves. Although this regulation was changed the following year, the grazing of livestock, especially sheep, in forest reserves was allowed sporadically for the next decade.

In 1905, the U.S. Forest Service was created under the Department of Agriculture. In effect, this removed forest reserves from the General Land Office (GLO) and placed them under U.S. Forest Service control. The GLO managed grazing of public lands outside forest perimeters prior to 1934. Comprehensive management of these lands was initiated in 1934 when Congress passed the Taylor Grazing Act. The Grazing Service was established with the implementation of the Act. Specific tasks within the Act included: establishment of a permit system, organization of grazing districts, fee assessment, and consultation with local advisory boards.

In 1946, the Grazing Service was combined with the General Land Office to create the Bureau of Land Management. Although there have been several attempts to merge the Bureau of Land Management and U.S. Forest Service, divergence in management philosophy and regulations affecting public lands continues to the present.

\section{Additional Readings}

Alward, G., L. Siverts, D. Olson, J. Wagner, D. Snef, and S. Lindhall. 1989. Micro IMPLAN: Software Manual. USDAFor. Ser., Colorado State Univ., Fort Collins, Colo.

NDA. 2001. Nevada grazing statistics report and economic analysis for federal lands in Nevada. Specifically Bureau of Land Management Lands, 1960 - 1999; Bureau of Reclamation, United States Forest Service, United States Fish and Wildlife Service, the National Park Service Lands, 1980 - 1999; and Total Federal Lands in Nevada, 1980 - 1999. State of Nevada, Department of Agriculture, and Nevada Association of Counties. 88p.

Pearce, R.A., D. Henderson, T. Harris, and T. Tetz. 1999. Impacts of federal land livestock reductions on Nevada's economy. Rangelands. 21:22-24.

Resource Concepts, Inc. 1998a. A review of public land grazing in eastern Nevada. 40p plus appendices. Resource Concepts, Inc. Carson City, Nev.

Resource Concepts, Inc. 1998b. A review of public land grazing in central Nevada. 37p plus appendices. Resource Concepts, Inc. Carson City, Nev.

Resource Concepts, Inc. 1997. A review of public land grazing in northwestern Nevada. 33p plus appendices. Resource Concepts, Inc. Carson City, Nev.

Rowley, William D., 1985. U.S. Forest Service Grazing \& Rangelands : A History (Environmental History Ser. Series, 8). Publ. Texas A\&M Univ. Press. College Station, Tex. 270p. 


\title{
Minimizing Wildfire Risk With Grazing
}

\section{Reducing fuel load with tools like proper grazing can help mitigate wildfire devastation.}

\author{
By Travis Brown, Representing the Northern Great Plains SRM Section
}

Lightning cracked across the sky like veins on the back of your hand.

It reached a fiery finger out, as if in reprimand,

And torched a crippled evergreen that leaned against

the sky,

While grass and sagebrush hunkered down that hellish hot July.

The tall pine tree exploded, and shot its flaming seeds, Like comets into kerosene, igniting all the weeds.

The air was thick as dog's breath when the fire's feet hit the ground,

It licked its pyrogenic lips, and then it looked around!

It offered up no quarter, and burned for seven days.

A hundred thousand acres consumed within the blaze.

Brave men came out to kill it, cutting trail after trail

But it jumped their puny firebreaks, and scattered 'em like quail.

It was ugly from a distance, and uglier up close, So said the men who saw the greasy belly of the ghost. It made 'em cry for Mama! Blistered paint on D-8 Cats! It sucked the sweat right off their backs and broke their thermostats!

Unless you've lived through a fire, (like the one Baxter Black describes in his poem) it's difficult to imagine this kind of sheer power and carnage. Montana lived through a summer of fires like that in 2000 , and in the aftermath of that devastation we find ourselves asking: Why did it happen? Will it happen again? And, maybe most importantly, what can we do to improve resource management and prevent a natural event like fire from creating such devastation?

There seems little question that better management can play a big role.
Improved range management is one area where we should focus. Allow me to explain some ways that range scientists are anxious to be involved in the solution to this huge challenge.

By August 2000 , Montana was in the grip of the $12^{\text {th }}$ hottest and $18^{\text {th }}$ driest summer on record. Forests were tinder dry, clogged with dead and dying trees, with an enormous fuel load, and the problem wasn't just in Montana.

The U.S. Forest Service, manager of over 190 million acres of America's land; said that 56 million acres were considered to be at high risk for catastrophic fire.

Even a General Accounting Office report stated the nation's forests were in poor health; that tree stands have grown denser, with increases in insect and disease infestation. The report went on to say these forests posed an immediate problem, the threat of disastrous wildfires! Just four months later, that threat became reality, in the most destructive fire season in decades

Most experts agree there are two main reasons why our forests had such a dangerous fuel load. First, an excellent job of fire prevention and suppression by the U.S. Forest Service over the past 90 years had prevented natural burning, leaving dead, dry timber and fuel to accumulate year after year. Smokey Bear was effective....all too effective!

Second, reductions in logging, and grazing, had reduced our ability to manage forests by selectively removing trees, thinning stands, and harvesting the grass and brush that provides fuel.

By summer's end, 82,000 wildfires had burned up nearly 7 million acres of land across America. We are talking about an area the size of the states of Rhode Island, Connecticut, Delaware, and half of New Jersey added together! The impact was devastating:

- people's livelihoods were ruined, 
- fish and wildlife habitat was destroyed,

- old growth forest was lost,

- livestock and wildlife died, and winter range was destroyed,

- range improvements were lost, including hundreds of miles of fence and water development projects,

- soils were eroded,.water polluted,..

- and enough timber burned, to build three and a half million homes!

\section{Managing To Avoid Fires}

The good news is that today, from the crucible of that summer's fires, is emerging a new philosophy for managing our national forests. Range scientists were heartened, when former Montana Governor Marc Racicot said, "The wild fire disaster of this summer presents a golden opportunity to change the entire legal framework that regulates management of the national forests."

One such plan is to fight fire with fire, by using smaller, carefully controlled fires that burn along the ground and kill the small brush and saplings, but spare the big trees whose bark is inches thick. Ideally such a cooler, less devastating, ground fire would sweep away the excess fuel every $8-12$ years.

Range resource managers like John Twitchell with the Colorado State Forest Department knows that livestock grazing can also play a big role. He writes that properly managed grazing can be an effective means of reducing fuel load, and stimulating range production.

Another plan is to follow the leadership of states such as Arizona and use tree thinning to reduce the density of trees, to mimic natural conditions. In parts of the west, there are a thousand trees per acre today, in the same places where the earliest pioneer journals only recorded a dozen per acre. With management, thinning, harvesting, and a carefully controlled burning program, we can slowly reduce the risk of severe wildfire and disease, the first step in ecosystem restoration.

In a letter to the head of the Forest Service and the Bureau of Land Management, the President of the National Cattlemen's Beef Association, George Hall said: "Proper livestock grazing is one of the most effective, and least expensive, methods of fuel management. When coupled with controlled burns, grazing can reduce the occurrence and the impact of catastrophic wildfire."

Further, the Chief of Range Management Research, for the Southern Forest Experiment Station in Louisiana, R. S. Campbell, explained how livestock grazing measurably reduces fire hazard by removing and breaking up potential fuel, citing research that moderate grazing removed 44 percent of herbage on experimental range in southern Georgia.

And yet there are those who still say, "Leave the forest alone! Stop the logging! End the grazing!" Well, what if we just do nothing?

Benjamin Stout, Retired Dean of the University of
Montana School of Forestry points out, and I quote: "If we stop managing National Forests, they will decline and die, just as they have done 16 times since the last Ice Age. As they move toward death, they consume less carbon dioxide, which means more air pollution and maybe more global warming."

The answer? Stout says: "Management..periodic harvesting followed by long periods of regrowth and renewal. This is the only known tool", he says, "for arresting the inevitable decline in forests. What's more, using wood we harvest, we can store carbon indefinitely, and prevent it's return to the atmosphere."

In summary, it seems there are several resource management tools that we can use to prevent, or at least mitigate forest fire disasters like the summer of 2000. Selective tree thinning, carefully controlled burning, and proper grazing management can make a big difference.

But we cannot wait! Because the problem gets worse every season. We cannot allow those who would stop all management, to simply let nature take it's course.

Because that course will not be pretty. Nor would it be responsible, and it would be very costly in loss of property, damage to environment, and even in human lives.

Mother nature has sent us a warning, like a wisp of smoke on a distant horizon. Whether we heed that warning is up to us!

Travis Brown's paper earned first place in the High School Youth Forum competition held at the 2002 SRM Annual Meeting in Kansas City.

\section{References}

Booth, William, Washington Post, (2000, September 26), reprinted in the Billings Gazette, pg 1, 12.

Cobb, Mike, (2000, October), The Explorer, Lewis \& Clark Conservation District newsletter, pg 4.

Dodder, Joanna, (2001, May 30) The Daily Courier, pg 1-2, "Prescott Arizona Official work on Circle of Protection"

Falstad, Jan, (2000, October 17) Billings Gazette, pg 1,8

Hall, George, (2000, August 15) National Cattlemen's Beef Association Press Release, "Grazing is an Effective Long-Term Solution for Fire Management."

Loftus, Bill, (2001 January), Logging Selectively, University of Idaho College of Agriculture Field Guide, pg 1-2.

Mader, T. R., (2000, September/October issue) Abundant Wildlife newsletter, pg 1-2.

Petersen, James, Evergreen Magazine, (2000 winter) Vol. 10, No. 21, pg 4-5, 13-17, 30

Seely, Ron, (2000, October 15) Billings Gazette, pg 1, 10.

Twitchell, John (2001), Colorado State University, Colorado State Forest Home Page,

http://lamar.colostate.edu/ statefor/grazing.htm

U.S.D.A. Forest Service, Northern Region, The Extent and Effects of the Fires of 2000 - A Preliminary Assessment, pg 2060. 


\title{
Rangelands In Jordan And Tunisia
}

\section{Challenges of the past and suggested solutions for future sustainable management.}

\author{
By Taoufik Ksiksi', Mohamed K. J. El-Shatnawi ${ }^{2}$ and Salah Chouki ${ }^{3}$
}

$\mathrm{R}$ angelands in Jordan and Tunisia play an important role in the economy of both countries. However, historical overuse of these systems has made it difficult and sometimes impossible to bring about remedial solutions. Following is an overview of the historical development of rangelands in Jordan and Tunisia and suggested ways to prevent further declines and develop sound management options for the benefit of the users, managers and the respective societies in general.

\section{Jordanian Rangelands}

In the Middle East, grazing of native rangelands began 11,000 years ago. Jordanian rangelands are mostly arid or semiarid, rainfall varies from less than 100 to $400 \mathrm{~mm}$. The climate in Jordan, being typical of the Mediterranean environment, is characterised by mild-humid winters and long hot, dry summers, and very short growing season with high variability in rainfall amount and distribution. Jordan is small $\left(90,000 \mathrm{~km}^{2}\right)$ but has five different rainfall zones: Jordan valley, arid lands, marginal lands, semiarid lands and semi-humid mountains.

Aridlands occupy more than $90 \%$ ( 8.5 million hectare) of the country's area and are distributed over seven ecological regions. Therefore most of the Jordanian rangeland may be considered as an ecosystem under non-equilibrium. In the Mediterranean Basin, rangeland production is closely relat-

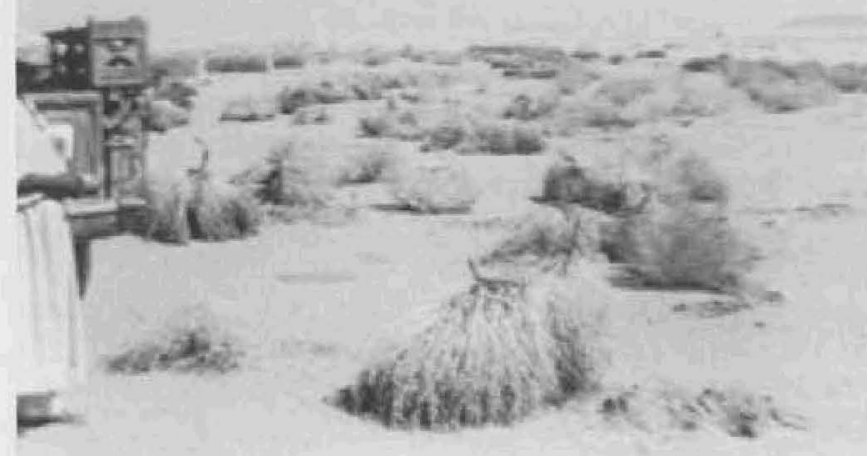

Jordan cutting shrub. ed to rainfall variability. The annual total evapotranspiration is about $1300 \mathrm{~mm}$.

Rangelands and forests have deteriorated due to long term abuses such as overgrazing, cultivation, and deforestation. Jordan asked for assistance in range improvement programs from the Food and Agriculture Organisation (FAO) of the United Nations. There is a need to start a program of improvement to repair the damage done through 100 centuries of overuse. Overuse caused advanced vegetation and soil deterioration. There is an increasing awareness by stakeholders of the urgent need for strategies and programs that aim at improving and managing rangelands.

Jordan has over 2.6 million sheep and one million goats, and the amount of supplemented feedstuff is estimated around 444 thousand metric tons. Systems of livestock production in Jordan are nomadic, semi-sedentary, mixed farming, intensive production and small family holdings. However, pastoral systems in the Middle East rely primarily on nomadism, transhumance and integrated cereal-livestock farming. Nomadism and transhumance dominate in arid areas. Integrated cereal-livestock farming system is used around villages and cities in the semiarid areas, which receive more than $250 \mathrm{~mm}$ average annual rainfall.

Nomadic herders have no permanent base. They take all their provisions with them as they move with their livestock. A 1994 report noted that the general nomadism features were (1) nomadism socio-political framework is tribalism; it is the loyalty of an individual to the tribe; (2) the presence of a hierarchical social structure in the tribe; (3) the decision which affects the individual family is taken by the head of the family. However, at times, some major decisions are taken by the family council of elders; (4) Illiteracy percentage among pastoralist is high; and (5) drought and high variability in rangelands productivity causes high economic losses and instability.

During the last two decades the characteristics of pastoralism have changed due to:

a. legal changes in the pasture areas from tribes and subtribes ownership to open free grazing or nationalised ranges and neglecting the old Hema (the old range reserve system developed in the Middle East to control common grazing)

b. the cultivation of marginal areas of grassland that receive good annual rainfall $(200-300 \mathrm{~mm})$, 
c. the overstocking around settlements and wells caused rapid, huge and sometime irreversible damages to vegetation and soil of the arid fragile rangelands,

d. the rhythmic movement from one area to another according to the availability of forages was reduced due to spread of livestock moving vehicles, limiting progressive grazing.

e. government feed subsides

f. restriction of movements through borders of neighbour countries

g. other various sociological, economical, political and legal problems.

The present seasonal livestock feed source in Jordan is to graze on marginal lands for 3 months, to graze on cereal stubble in rain-fed areas for 4 months, to graze on natural pasture in rain-fed areas for 1.5 months and to feed supplements for 3.5 months. The big challenge facing the country is how to raise productivity of the arid rangelands.

A well-organised program for the development of rangelands would have considerable economic and social benefits. Further delay in providing support to restoring these areas poses serious hazards, such as progressive erosion, threat of desertification and lowering income, which leads to migration to urban centres.

Research projects have been started to find adapted and productive species for reseeding, and to increase water harvesting in these arid rangelands. Lack of progress in range improvement appears to be a result of poor long-term integrated planning, failure to recognise the seriousness of rangeland problems and lack of innovation to address them. Planners recognise the urgent need to gain self sufficiency in agricultural products using the potential of natural wildlands. For full recovery of these severely depleted lands, a range development and improvement program must be implemented to establish and maintain valuable forage resources.

\section{Tunisian Rangelands}

Like in Jordan, population growth in Tunisia during the past forty years has triggered a dramatic increase of livestock numbers in the country. Sheep and goat population has increased by more than two-fold between 1964 and 2000. Simultaneously, the large nomadic herds that grazed the area in the past have been replaced by small poorly managed flocks, as the livestock systems changed from nomadic to sedentary farming. This new lifestyle has been accompanied by converting the most fertile grazing lands to cereal, olive, or almond production and establishing yearlong grazing of the remaining rangelands.

Little attention has been given to the development of forage crops and agricultural by-products or to the improvement and the management of natural rangelands. Insufficient rainfall and overgrazing has contributed to a serious soil and vegetative cover deterioration of existing rangelands and feed deficits are continuing.

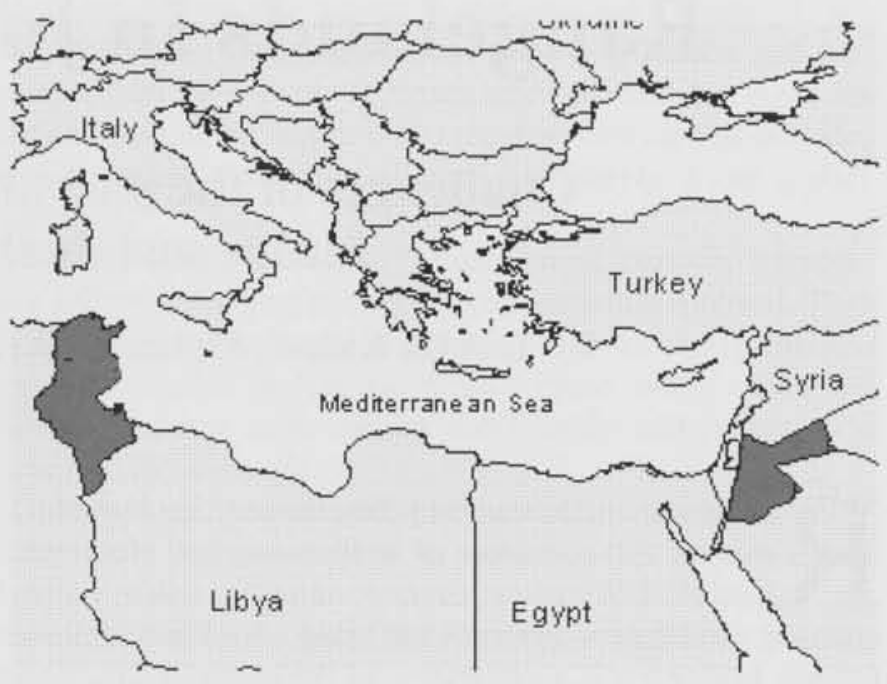

Locality map of Tunisia (left) and Jordan (right).

Tunisian territory covers more than $16 \mathrm{M}$ hectares. Forest and natural rangelands occupy around $33 \%$ of the total area. The most obvious constraint on livestock production in the country is the shortages of animal feed. Rangeland areas have become degraded as a result of overstocking resulting in a severe reduction of carrying capacity. Rangelands have been converted to cereal and fruit trees plantations, whose contribution to annual feed requirements is more and more limited. Supplementation from other sources of forage, by-products and concentrates is becoming increasingly needed. The changes of marginal land and other land areas have contributed to huge annual reductions of animal feed. For example, between 1979 and 1988 , areas covered by cultivated lands increased by $17.7 \%$.

Areas with less than $250 \mathrm{~mm}$ precipitation, lands that once were productive grazing lands, are now converted to marginal farmland producing cereal crops only 2 years out of 5 . During years of adequate fall rains farmers plant cereal which may be grazed if spring rainfall is low. During years of inadequate fall rains farmers keep their lands for grazing. The improvement toward the restoration of the soil vegetative cover has become difficult or impossible.

The high rate of crop failures due to inadequate and inconsistent rainfall has resulted in much of the marginal cropping reverting back to grazing, leading to low value forage plants as the prominent source of livestock feed. Palatable range species have partially or fully disappeared and the soil degradation reached $75 \%$ in some areas. Up until 1960 , livestock numbers were highly affected by the climatic conditions which periodically reduced the available forage. The cyclic periods of drought led to huge animal losses. Since 1960, even though rangelands continue to decrease, the impact of drought periods on livestock feed resources decreased due to the progressive modifications in 
the livestock production and feeding systems. Farmers adopted diversified types of storable feed resources such as hay, urea treated or untreated straw, silage, secondary cereal crops, by-products and industrial feeds (concentrate, alfalfa pellets). In cases of serious droughts, government agencies organise and encourage the importation of necessary feeds. No substantial reductions in livestock numbers occurred since 1979.

Nowadays, Tunisia counts around 6.5 million sheep, 1.3 million goats, and 748,000 cattle. The total feed need is around 4,400 million Forage Units (FU), with a total amount of supplemented feed stuff based on imported barley grains topping the 670,000 tons mark (1995 figures). Due to the evolution in land use (expansion of cereal cropping and arboriculture), the contribution of rangelands decreased by about $39 \%$ in 25 years. In 1964, rangeland production covered $84 \%$ of the feed needs of central and southern regions and $63 \%$ of the total livestock need of the country. This contribution has decreased to around 20 to 25 percent during the last decade. In 1990, a favourable year, the contribution was only about $24 \%$ due to the expansion of cereal cropping and arboriculture upon rangelands. There is an even more serious problem in southern Tunisia, where more than $30 \%$ of the total sheep population is raised, with very unproductive rangelands. Moreover, a large part of the extreme southern rangelands are unused due to lack of watering points, rural roads and absence of shading zones.

Today, rangeland total production is around 1,200 million forage units during rainy years, decreasing to less than half during dry years. Livestock feed needs are around 4,400 million forage units to reach 5,200 million forage unit in year 2006. Rangelands contribute by between 10 and $25 \%$ in livestock feeding, while fallow provides 10 to $20 \%$. Cultivated forage crops provide 10 to $15 \%$, agricultural and industrial by-products provide 25 to $30 \%$ and feed concentrates (barley and alfalfa pellets) provide 15 to $40 \%$ of livestock feeding.

Recognizing the seriousness of range degradation and feed deficits, the government has strengthened its program for the development of degraded natural rangelands. For decades, in order to face an increasing demand of animal products, the government implemented measures to alleviate the impact of feed deficits on livestock management by ensuring the implementation of intensified and integrated livestock programs. Some of these measures are:

a. improving forage production to increase animal feed resources,

b. combating land degradation, land erosion and desertification phenomena,

c. increasing of training programs for the range management specialists,

d. promoting applied field research programs to diversify the forage species related to each specific bioclimatic zone, and e. instigating subsidies and price support policies.

Several local major range improvement achievements during the last two decades reached around 711,000 hectares using various techniques centred around improving range condition and community awareness. For instance, some of these development programs improved some degraded lands by planting about 211,500 ha of spineless cactus and about 225,000 ha of shrubs, such as saltbushes (Atriplex nummularia and A. halimus), acacia cyanophylla, alfalfa shrubs and other native shrub species and deferring about 274,500 hectares.

These various schemes and programs have, at various extents, reduced land degradation of Tunisian rangelands. A long-term concerted effort is still needed to make these programs deliver better outcomes.

\section{Sustainable Management Of These Rangelands}

It has been widely publicised, and rightly so, that rangelands have been greatly overgrazed and degraded, particularly in developing countries. How can farmers sustainably manage rangelands when survivorship is in question? How can farmers think sustainability when their livelihood is dependent on few underfed weak grazing animals?

Unlike farmers in developing countries, those in developed countries live a life of funding availability for relatively many kinds of schemes, initiatives and programs. Many of the programs in developed countries, such as the USA and Australia, are part of a bigger focused strategic framework. And that has been a strong basis for their success.

For any success stories in rangeland management in Tunisia and Jordan, therefore, it is believed that there is a pressing need for very focused targeted subsidy programs funded and incorporated mainly by the World Bank and FAO development programs:

a. Education and technical expertise of rangeland specialists

b. Provision of low interest loans to governments to provide subsidies to those relying on rangelands and livestock for their life. A set of very focused criteria is to be a measure of eligibility for assistance

c. Education of farmers about on-farm rangeland improvement strategies in conjunction with monthly subsidies to farmers relying on rangelands as sources of income, are direct remedies to the problem of overgrazing and rangeland degradation.

These initiatives/programs would, in turn, strengthen not only farmers' understanding of natural resource management, but also their appreciation for what the land provides for them and the generations that follow. Social aspects of farming are extremely important for younger farmers to respect the land and take the torch to finish what the ancestors have tried to accomplish. Organisations, such as the World Bank and FAO, should revisit the ways they implement these types of interventions. For instance, full consul- 


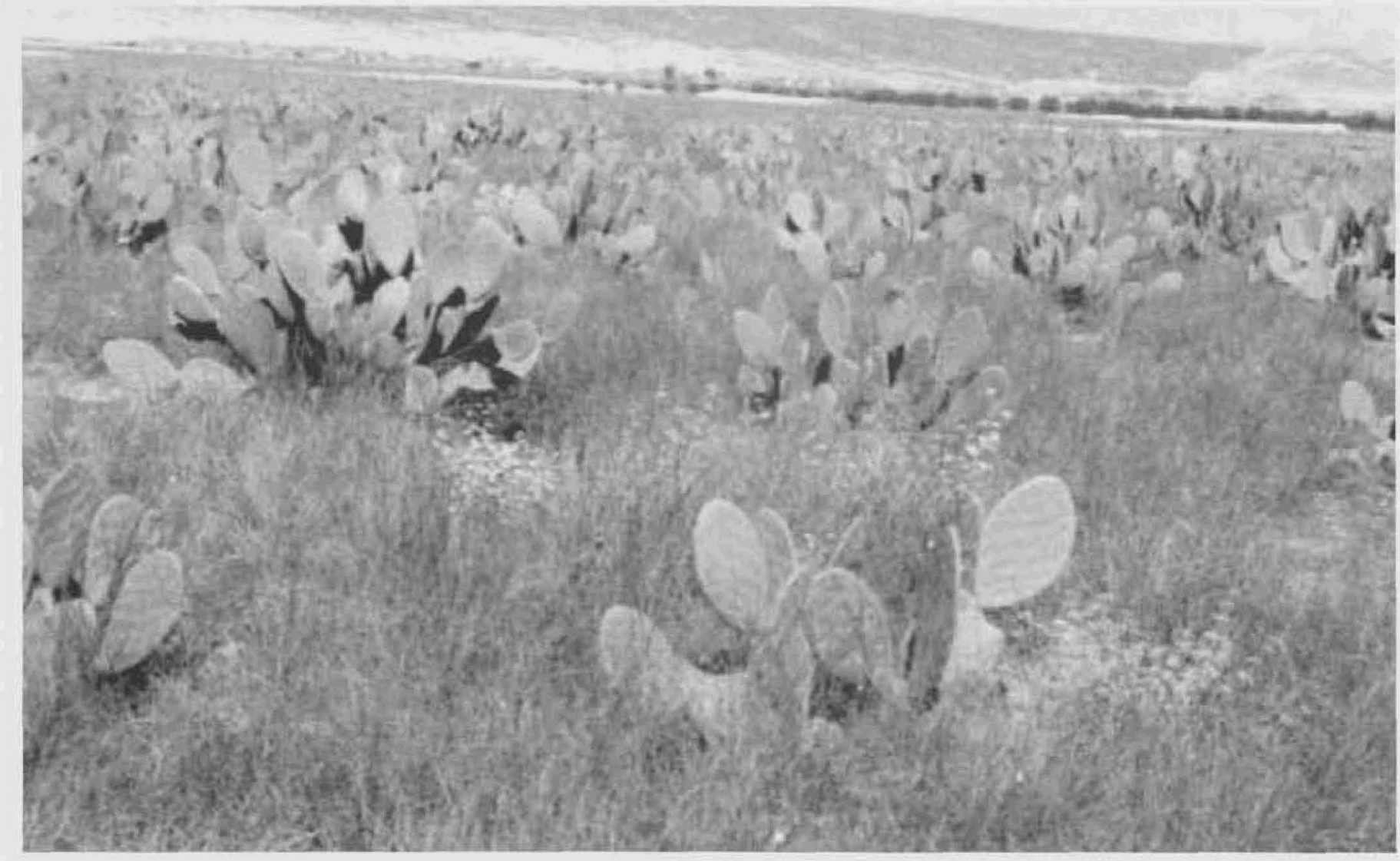

tations/collaborations with farmers, in close partnership with government agencies, is required in order to achieve positive outcomes. This does not entail an increase in funding but rather a better use of the current support.

Authors are: 'Rangeland Ecologist. Agency for Food and Fibre, QDPI, Australia; ${ }^{2}$ Associate Professor of Range Ecology, Faculty of Agriculture, Jordan University of Science. Irbid, Jordan; ${ }^{3}$ Regional Manager, Office de l'Elevage et des Paturages, Tunisia.

\section{References}

FAO. (1988). Jordan small ruminant development projectIdentification report. 26/88 IF-JOR 5-FAO, Rome.

FAO. (1994). Sheep Production Under Extensive Systems in the Near East. Jordan pastoral system: A case study. Near East Regional Office Food and Agriculture Organisation of the United Nations. Cairo, Egypt.

Jaradat, A.A. (1988). An Assessment of Research Needs and Priorities for Rainfed Agriculture in Jordan. Published in Jordan by the United States Agency for International Development.
Le Houérou, H.N., (1969). Contribution des différentes ressources alimentaires a la couverture des besoins du cheptel en 1964 in: Programme de développement de la production fourragère et de l'elevage, FAO, 1998.

Le Houérou, H.N. and C.H. Host. (1977). Rangeland production and annual rainfall relations in the Mediterranean basin and in the African Sahel-Sudanian Zone. J. Range Manage. 10:265-270.

Ministère de l'Agriculture. (2000). Resultats de l'enquète sur le suivi de la campagne agricole 1998-1999.

Noy-Meir, I. and N.G. Seligman. (1979). Management of semi-arid ecosystems in Israel. In Walker, B.H. (ed). Management of Semiarid Ecosystems. Elsevier Sci. Pub. Co.. Amsterdam.

Park, B.C. (1955). Use of photo mosaics as a base for range resource inventory in the Hashemite Kingdom of Jordan. J. Range Manage. 8:257-264.

Tiedeman, J.A. and S. Chouki. (1989). Projet d'amélioration et de gestion des parcours de la Tunisic Centrale. Rapport Final.

World Bank. (1995). Une strategie pour le développement des terrains de parcours en zones arides et semi-arides. Rapport technique Tunisie. 


\section{Resource Roundup}

\section{Software Helps Analyze Forage \\ Data}

To help keep better records for grazing management, Texas A\&M University's Rangeland Ecology and Management Department has developed The Grazing Manager (TGM) for Windows software. TGM can be used to inventory forage and animal resources, and plan, monitor and adjust grazing management in response to current year's forage growth conditions.

For more information, go to http://rangeweb.tamu.edu/arm and follow the link to The Grazing Manager software. Or, contact Ray Hinnant at (979)845-5580 for more details.

\section{Molasses Blocks Can Entice Livestock}

Range managers often use salt to help attract livestock to seldom grazed areas. Working from that same principle, a Montana study looked at the effectiveness of low moisture molasses blocks as an attractant.

The study was conducted by Derek Bailey, an assistant professor with Montana State University based at the Northern Ag Research Center in Havre. His research indicates that strategically placed molasses blocks can be even more effective than salt at getting cattle to utilize seldom used areas such as rugged terrain.

"The molasses tubs appear to be a more powerful tool than salt, especially in late summer and fall and winter," Bailey says. "Cattle had a higher preference for the molasses and used it more consistently." He credits that to the fact that the molasses is high in protein and more palatable. "It's a better nutritional reward than salt."

Bailey says that once cattle are attracted to an area with the molasses tubs, his research indicates the cows will lick the supplement and then graze about 600 yards from the area.

"We've been able to gain $10-15 \%$ utilization in more rugged areas. For example, where we once had $5 \%$ use, with the blocks we may now have $20 \%$ use," Bailey says.

He points out that the extra forage being utilized pays for the cost of the supplement. "And, that doesn't even factor in the nutritional value of the supplement," he says.

If you plan to use salt or molasses blocks/tubs (or the two together,) Bailey suggests first putting the supplement near water to introduce cattle to it. After a few days, move it out a quarter to half mile from water. As animals utilize the forage around the supplement, continue to move the blocks up slope and further out.

\section{Stacking Affects Storage}

Although stacking large round bales in pyramids saves space, it may not be the best method for preserving hay quality. A South Dakota study found dry matter losses of more than $10 \%$ for prairie hay stacked in pyramids, compared to $4 \%$ for bales stacked individually and less than $1 \%$ for bales stacked end to end. Researchers say stacking large round bales pyramid-style tends to trap moisture and limits drying from exposure to the sun and wind.

Fortunately, good management can help preserve hay quality. Here are some guidelines:

Consider moisture content-Hay baled with excessive moisture tends to deteriorate more quickly. Large round bales are best put up at $16 \%$ to $18 \%$ moisture content.

Make a dense bale-A dense bale will sag less, have less sur- face area in contact with the ground, and shed more precipitation.

Store bales on a well drained location-Bales soak up moisture if placed on a wet or poorly-drained site, causing a large layer of spoiled hay on the bottom of the bale. Thus, select a storage site that is a well-drained, such as the ridge of a hill. Where practical, keep bales off the ground using low-cost materials like pallets, racks, fence posts, railroad ties, used tires or a 6 -inch base of crushed rock.

Store bales end-to-end-Position bales end-to-end in long rows oriented north-south (if possible) and provide at least 3 feet of space between rows. This storage combination will provide for good sunlight penetration and air flow, which will allow the area to dry faster after a rain. It should also reduce snow accumulation between rows.

When lining bales up, put the stem-down side of the bale to the north side. The stem-down side tends to shed rain and snow better than the stem-up side. The stem-up side will then receive more sun to provide some melting and drying to lessen spoilage.

Avoid trees and fences-Locate bale rows away from fences and tree lines to avoid contact with snow drifts. Shading and blocked wind circulation from trees will cause more substantial damage to the hay bales than any rain protection trees might offer, experts say. Instead, store bales in an area open to breezes to enhance drying after rains.

Keep grass and weeds mowed between rows so they do not shade the bales or hold snow or extra moisture in the area.

Bales as windbreaks - If you plan to utilize round bale rows as a snow fence, orient them opposite the prevailing wind direction to catch as much snow as possible.

For added wind protection, consider stacking the bales in the "Canadian" method - turn one bale on end and then stack another on top of it.

A Kansas State University study indicates this may be a feasible stacking method. The study found dry matter and quality losses were similar to those of bales stored end to end in north-south and east-west rows. Hay spoilage at the bottom of the bale was higher for this method, but less hay is exposed to the ground.

\section{New NRCS Chief Named}

Bruce Knight was named chief of the USDA Natural Resources Conservation Service (NRCS) in late March. Knight will oversee the 11,000-person agency with a budget of $\$ 1.1$ billion.

He officially joined USDA on May 6. Prior to his NRCS appointment by Secretary of Agriculture Ann Veneman, Knight served as vice president of public policy for the National Corn Grower's Association's Washington, D.C. office. Knight previously served on the staff of Kansas Senator Bob Dole, focusing on development of the conservation title of the 1996 Farm Bill.

A native of Gann Valley, South Dakota, Knight has been a farmer and rancher since 1976 for a 1,500-acre diversified grain and cattle operation using no-till and a rest rotation grazing system. Knight succeeds Pearlie Reed, who served as NRCS chief since 1998 .

Resource Roundup is compiled by Kindra Gordon. Contributions welcome at kindras@gordonresources.com or call (605)722-7699. 


\title{
Goats And The Need For Range Management In Mexico
}

\section{Current goat production practices in the state of Durango, Mexico have lead to overgrazing and a need for educating producers about range management. Here's a history.}

\author{
By Edmundo Castellanos-Perez, Manuel Valencia-Castro, Jesus J. Quiñones-Vera
}

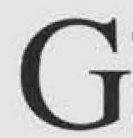
oat production in the Chihuahuan Desert in Mexico is carried out by the poorest livestock producers of the country. Goats provide milk which is a source of a daily income or at least provides producers with an inexpensive source of protein. The reproduction of goats is also a means to increase the producer's income in one season of the year and in rare occasions the reproduction of goat kids happens two seasons of the year.

Following is an overview of the main goat production systems in the region of the Durango State corresponding to the Chihuahuan Desert. In this area, there are two dominant systems, the extensive system in rangelands dominated by brushwood vegetation in Ejidos, and another extensive system where goats graze crop residuals, grasses growing in water channels, and weeds in the intensive agriculture area in the region named La Comarca Lagunera.

\section{Goats On Brushwood Rangelands}

The information in this system is based on an overview of the Ejido Pasaje that belongs to Cuencame County of the State of Durango. This Ejido is located at $24^{\circ} 54^{\prime}$ north latitude and $103^{\circ} 47^{\circ}$ western longitude. Vegetation is crassicauleous brushwood dominated by species of Opuntia, Acacia, Agave, Eysenhardtia, Rhus, Prosopis, Celtis, Lycium and others. Also some areas are dominated by Larrea tridentata and Fluorensia cermua. Precipitation average is $300 \mathrm{~mm}$ occurring mainly in the summer, average temperature of the coldest month is $10-20^{\circ} \mathrm{C}$ and the hottest $20-30^{\circ} \mathrm{C}$ (Medellin-Leal 1982). The total area is 28,000 ha, where there are 412 ejidatarios, the owners of this land, and 112 of them have goats.

Each ejidatario has 5 to 20 ha dedicated to the agriculture of private propriety. This land is provided for by a new law

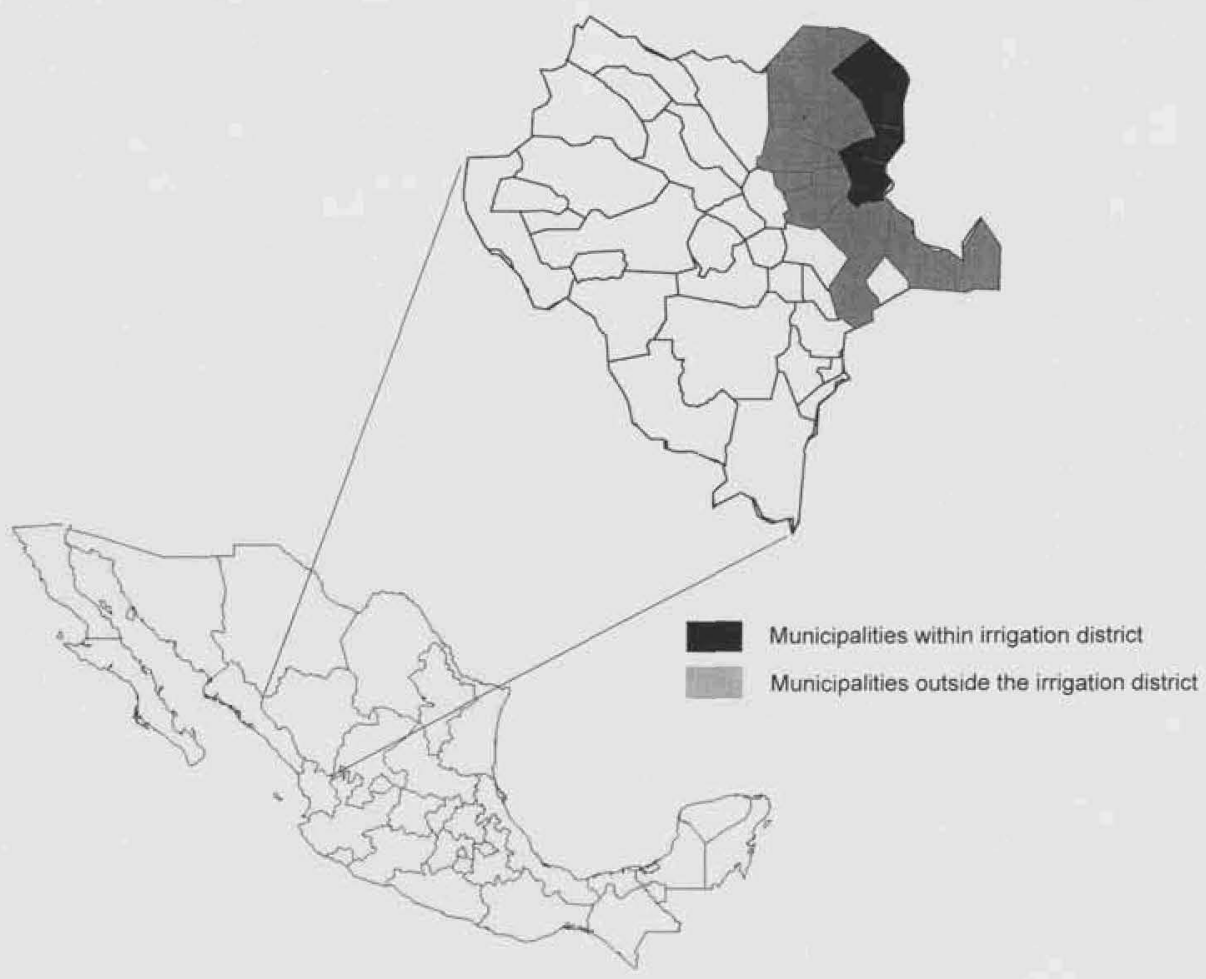


written in the government of the ex-president of Mexico Salinas-de Gortari (1988-1994). The areas of agriculture are mainly irrigated with runoff water diverted from arroyos. This type of farming means that ejidatarios have crop production only after summer rainfall occurs. The area not dedicated to agriculture is mainly dominated by brushwood vegetation, grazed by livestock and some deer. This area is for common use, in other words, all the ejidatarios can use this area if they have animals to collect the forage. Generally, each ejidatario has private cattle and/or goats, and they use burros, mules, and/or horses for transportation.

Goat grazing in this extensive system is basically opportunistic. Goats are moved to any area where rainfall has occurred and the vegetation has become green. To maintain water in these areas of green vegetation, people make jaguieyes, which are small dams of soil across the arroyos bottoms. This traps the runoff water. Ejidatarios know that if there is no winter rainfall the forage production of the brush vegetation will be minimum with the period from January to June having a critical food shortage. During this period, water is provided from dug wells or natural springs. These areas near the water have a high degree of overgrazing (Holechek et al. 1995).

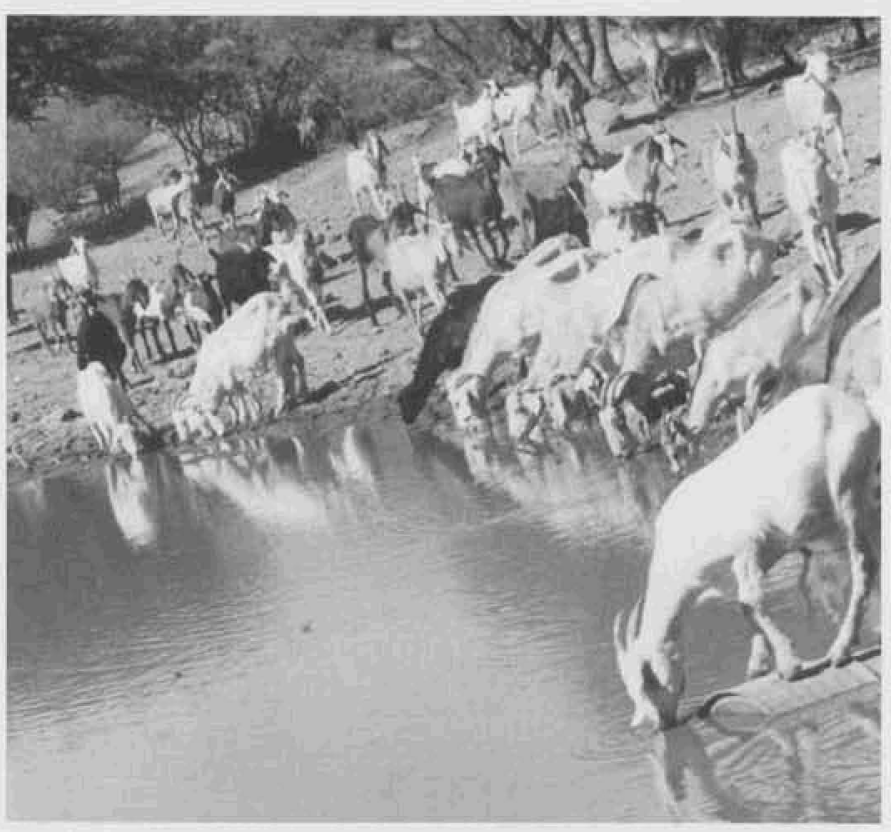

A jagüey with goats drinking water.

Corrals are very rustic because herds are moved three times per year, always searching for the best grazing area or the availability of water in the winter through spring period. Corrals are made using stems and branches of mesquite, white-thorn (Acacia constricta), ocotillo (Fouquieria splendens), and other shrubs.

In this area, producers invest a great deal of energy taking care of their animals, but they pay little attention to im- proving the grazing range. They always try to move their animals to the best forage areas, to make sure that goats get the best food available. The worst thing for a livestock producer is to see animals die due to starvation during drought periods usually between July and September.

Emergency forage is provided by burning the spines of Opuntia imbricata. Another plant used is the palma (Yucca $s p p$ ) which is cut, then the sharp blades are taken away and the stem is cut in small pieces $(2 \times 2 \times 2 \mathrm{~cm}$ approximately). They also collect nopal (Opuntia spp) and after burning the sharp needles, the 'pencas' (racquets) are cut in small pieces and given to the goats.

Since each ejidatario owns as many animals as he can feed and they all use the common rangeland areas of the ejido without any restrictions, everyone tries to get the plant products, (in this case: the forage) without considering the remaining part of the plant and its implications for the next growing season. Unfortunately, that practice leads to overgrazing (Committee on Rangeland Classification 1994). Additionally, severe droughts contribute to a serious problem of soil erosion which often results in big gullies (Ellis and Swift 1988, Gibbens and Beck 1988).

Ejidatarios do see the problem but they assume that if they do not use the grasses or shrub forage of the ejido, other ejidatarios will do it. This overgrazing is a common problem in the rangelands that support the goat or beef cattle industry.

Erosion is notorious in bajadas (alluvial plains with a light slope), where large bare ground patches are visible. Runoff erosion has accelerated the formation of huge deep gullies. Local people say that in areas where they built jaguieyes in the past they had a good grass ground cover. Unfortunately, overgrazing plus droughts have turned many of these grassland areas into less than favorable grazing locations.

It is important to understand the animal reproduction procedure in these areas. In the late nineteenth century, before that area became an ejido, there was a restrictive use and reproduction program that followed the summer rainfall period. At that time, they separated the male goats from April to January, joining male and female goats in February, usually one male for 25-30 females in each herd. That practice allowed the production of kids in June and July just in time for the summer rainfall. During the years that rainfall amounts were over the average, they would join the males and female goats at the end of the summer. That practice provided an additional income in the winter from the sale of the kids.

Since the average herd is between 100 to 300 animals, they have a uniform nursery method. When a female goat has parturition, the kid or kids are tagged with a number by cutting hair on the left side of the rumen. Also the same number is tagged to its mother on the same place. Female goats graze without their kids. The kids are left in the corral because they are too young to walk the several kilometers per day that the goats usually have to cover to get their 


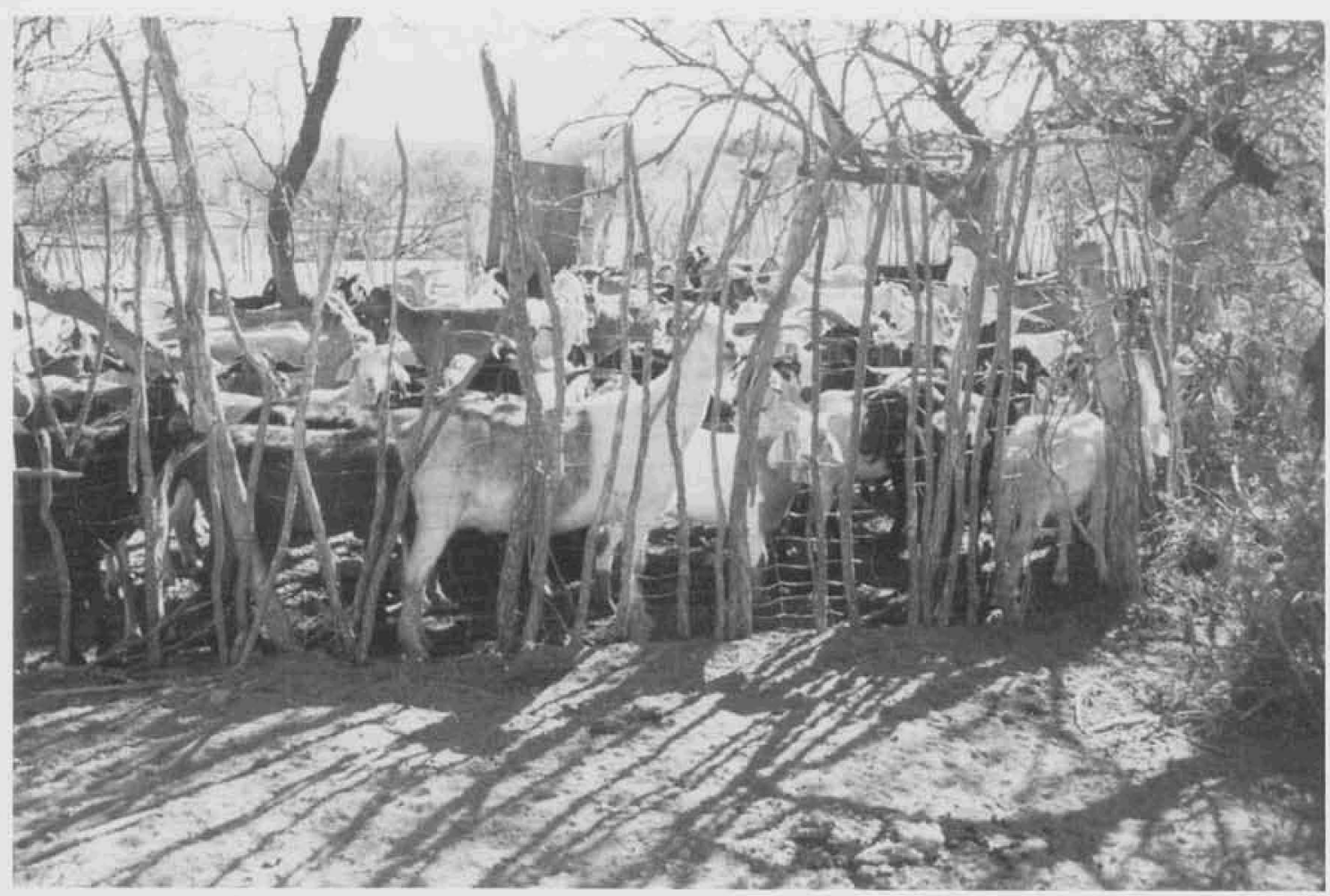

A corral made with ocotillo stems.

forage in the rangelands. Before goats come back to the corral, around sunset, a worker ties the kids in their respective place by putting one end of a thin rope around one leg and the other side of the rope is tied to a wood stake buried in the ground. In this way female goats always know where they can locate their kids to nurse them.

When female goats are close to the parturition time they are left in the corral one or two days until after birth occurs. When a mistake is made and a female goat is not left in the corral during that time and its kids are borne at the grazing area, the kids are nourished and tied by their four legs around the neck of their mother until they arrive to the corral in the evening.

The percentage of twin births is around 50\% and generally the young goats start breeding from the time they turn 18 months old. Adult goats are sold when they are 6-7 years old depending on their reproductive record or the needs of the livestock producer. The milk production period is $3-5$ months after parturition. Ejidatarios in this region do not use any kind of vaccines in their animals and supplemental protein and mineral use is rare in this kind of system.

\section{Goat Production In Intensive Ag Areas}

The Comarca Lagunera is an intensive agricultural area by using mainly water of the Nazas river that originates in the Sierra Madre Occidental. Another important river is the Aguanaval river which begins in the Zacatecas State. Both rivers used to flow to a closed watershed in the lagoon named Laguna de Mayran, but the dams and channels built for a better irrigation control has dried this lagoon. The Comarca Lagunera is located between $24^{\circ} 30^{\prime}$ and $27^{\circ}$ north latitude and between $102^{\circ}$ and $104^{\circ} 40^{\prime}$ west longitude. The average rainfall in this area is $200 \mathrm{~mm}$, precipitation occurs mainly in the summer season and winter is usually dry. The average temperature in the coldest month is between 10 and $20^{\circ} \mathrm{C}$ and the hottest month is $20-30^{\circ} \mathrm{C}$ (Medellin-Leal 1982).

Forages are obtained mainly for dairy cattle, and there are some areas with irrigated crops producing corn, bean, and cotton. Usually people who live and raise goats in this rural area generally do not have any private or ejidal possession of land. They use goats for collecting residuals of crops where there are not fences. Goats also graze former croplands that have been abandoned due to the decrease of the water availability. Fourwing saltbush (Atriplex canescens) and mesquite have invaded these areas. The evergreen fourwing saltbushes are good forage for the goats.

In these areas, the highest availability of forage is in the summer and fall seasons because the rainfall is used by plants growing in abandoned areas and moreover in the fall season there is crop residual in areas where bean or maize were harvested. Low amounts of forage from January to June is observed because there are no residuals of crops of the winter season.

The reproduction of goats according to Valencia-Castro (1998) is determined by producers who breed their females usually once per year, where $37 \%$ of the livestock operators maintain the males with the female goats the whole year, 
and a $34 \%$ breed their goats from June to September. Usually kid production is from November to September. Producers only have a rustic corral for protection in the night. They rarely give supplementation to their goats. Daily milk is produced for 3-5 months long after the parturition. People take care about animal health because they see low production or weight loss when animals get sick. Mortality is about $9 \%$ in adult animals and abortion about $12 \%$ due to low nutrition levels or illness. In this area there is not a problem of overgrazing.

\section{A Need For Range Management}

Whereas there is severe overgrazing in the area of brushwood rangelands, this is not a real problem in the agriculture areas. In the brushwood rangelands, people are aware that their goats are overgrazing the land because a lack of internal control in the Ejido. It is necessary to organize and create a grazing system where the priority will be at least to stop overgrazing. Although this action alone will not return rangelands to their initial condition, at least, it will be the beginning of actions conducive to the restorations of these areas.

The life of the goat producer is hard, and he lives in poor conditions. Grazing on these eroded lands is difficult to get access to good forage and water each day. The producer knows it, therefore if these people had access to other options they would leave this activity or they would accept an adequate management system of the renewable resources of these lands. If they could be confident that the distribution of land use would be fair they would forget their present motto "if my animals do not eat these plants, other animals that are not mine will eat them anyway and I will not get any benefits".

They need to know how to take care of their rangelands and they need to understand some of the ecological processes that plants endure (Joyce et al. 1999). With the help from rangeland managers, they would know when plants must be grazed and how much biomass would be removed without any damage to the plants and the environment (Holechek et al. 1995). Furthermore, it is very important to establish a law which mandates a change in the overgrazing pattern that has created a dangerous situation in the rangeland of Mexico and is very detrimental to our nation.

Authors are associated professors at Facultad de Agricultura y Zootecnia, Universidad Juarez del Estado de Durango, Mexico.

\section{References}

Committee on Rangeland Classification. 1994. Rangeland Health: New Methods to Classify, Inventory, and Monitor Rangelands. Board on Agriculture, National Research Council. Washington DC. $180 \mathrm{p}$.

Ellis, J.E. and D.M. Swift. 1988. Stability of African pastoral ecosystems: Alternate paradigms and implications for development. J. Range Manage. 41:450-459.

Gibbens , R.P. and R.F. Beck. 1988. Changes in grass basal area and forb densities over a 64-year period on grassland types of the Jornada Experimental Range. J. Range Manage. 41:186-192

Holechek, J.L., R.D. Pieper, and C.H. Herbel. 1995. Range Management: Principles and Practices. $2^{\text {nd }}$ ed.Prentice-Hall. Englewood Cliffs, NJ.

Joyce, L.A., J.J. Landsberg, M. Stafford Smith, J. Ben-Asher, J.R. Cavazos Doria, K. Lajtha, G.E. Likens, A. Perevolotsky, and U.N. Safriel. 1999. Ecosystem-level consequences of management options, p. 97-113. In: T.W. Hoekstra and M. Shachak (eds). Arid Lands Management:Toward Ecological Sustainability. University of Illinois Press. Urbana and Chicago, III.

Medellin-Leal, F. 1982. The Chihuahuan desert, p. 321-381. In: G.L. Bender (ed). Reference Handbook on the Deserts of North America. Greenwood Press. Wesport, Connecticut.

Valencia-Castro M. 1998. Sistemas de produccion caprina en la Comarca Lagunera. Memorias del ler. Congreso Internacional de Medicos Veterinarios Zootecnistas Practicantes en Rumiantesde La Comarca Lagunera. Gomez Palacio, Dgo. 22 y 23 de Mayo de 1998. pp 191-201

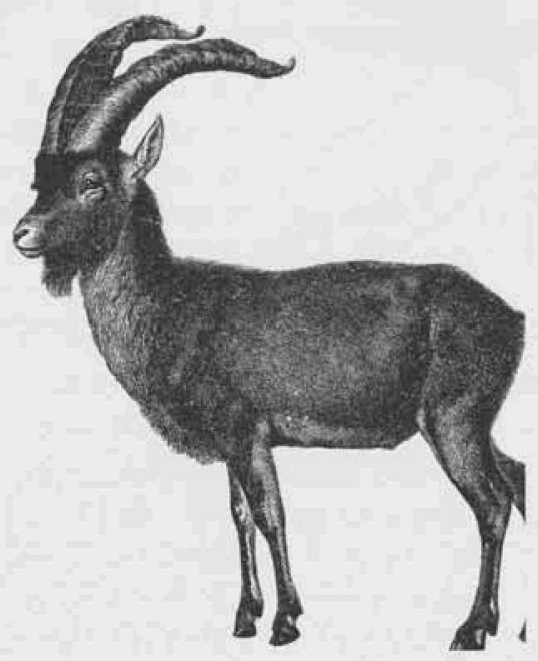




\title{
Assessing Browse Trend At The Landscape Level Part 1: Preliminary Steps And Field Survey
}

\author{
By Richard B. Keigley, Michael R. Frisina, and Craig W. Fager
}

$\mathrm{W}$ oody plants are an important component of rangeland habitat, providing food and shelter for animals that range in size from moose to warblers to insects. Because of this importance, land managers are paying increased attention to browse trends. In this two-part article, we describe how browse trend is assessed at the Mt. Haggin Wildlife Management Area in southwestern Montana.

Located south of Anaconda, Montana (Fig. 1), winters are extremely cold and windy at the Mount Haggin Wildlife Management Area. The annual precipitation is about 20 inches, much of which occurs as snow.

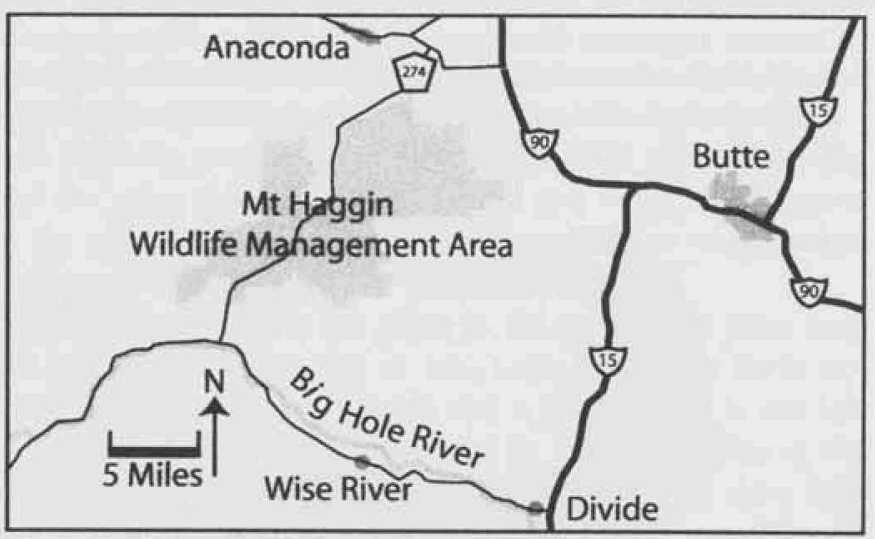

Fig. 1. Map of study area.

There are resident and transient ungulate populations. Moose is the only ungulate species present in all months. Elk, mule deer, and pronghorn antelope are present much of the year, but cannot contend with the deep snow cover that exists during mid-winter. Whitetail deer and cattle are present during the warm season. Cattle are managed under a three-pasture rest-rotation grazing system.

During the fall, a significant transient moose population is present. As snow cover deepens in the Pintler Mountains to the west, moose migrate from those mountains and stage in the area before migrating to lower elevation winter range in the Big Hole Valley. Over the past three decades, the moose population has increased. Censuses by Montana Fish, Wildlife \& Parks in the 1970 s reported an average of

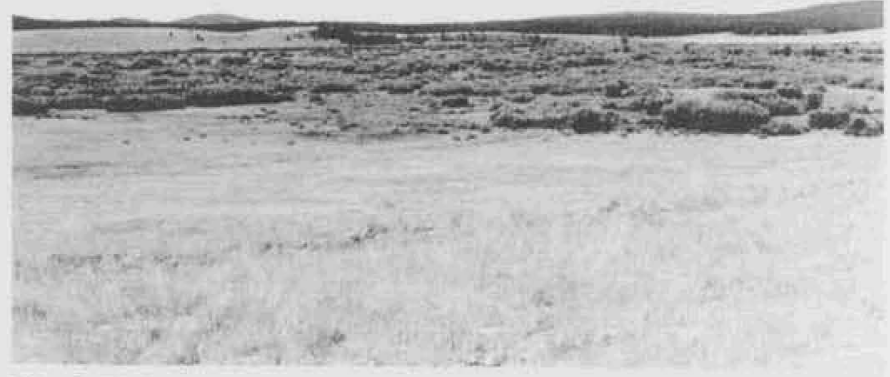

Fig. 2. Willow community provides critical habitat for wildlife.

9 animals; in 1980s, an average of 19 animals was reported; in the 1990s, an average of 39 was reported.

Willows present in the study area include Geyer, Drummond, Booth, planeleaf, Scouler, and Wolfs willow (Fig. 2). The riparian species are found in two general kinds of valley bottoms. At the lower end of drainages, the valleys tend to be wide and flat-bottomed, and locally bordered by glacial moraines. Within some of the flat-valleybottom areas, willow communities are confined to the corridor immediately adjacent to relic or current stream courses. At other locations, ponding caused by beaver dams, has allowed willow communities to spread across a broad area. At the upper end of the drainage, willows are confined within relatively narrow, $v$-shaped valleys. In the upper drainages, conifers often are present within the willow community.

Willows are currently heavily browsed (Fig. 3), but there is evidence that browsing pressure was lower in the past. Heavily-browsed 14-inch-tall plants grow in close proximity to 16-foot-tall plants, the tallest stems of which are unbrowsed (Fig. 4). The 16-foot-tall stems are older than the 14-inch-tall stems, and apparently grew through the browse zone when browsing pressure was lower than its current level. An increase in browsing pressure would be consistent with the increase in the moose population that occurred over the past 3 decades.

Our trend assessment involved five steps. Steps 1 through 3 were preliminary to the actual assessment of trend. Actual trend assessment occurred during steps 4 and 5 . 


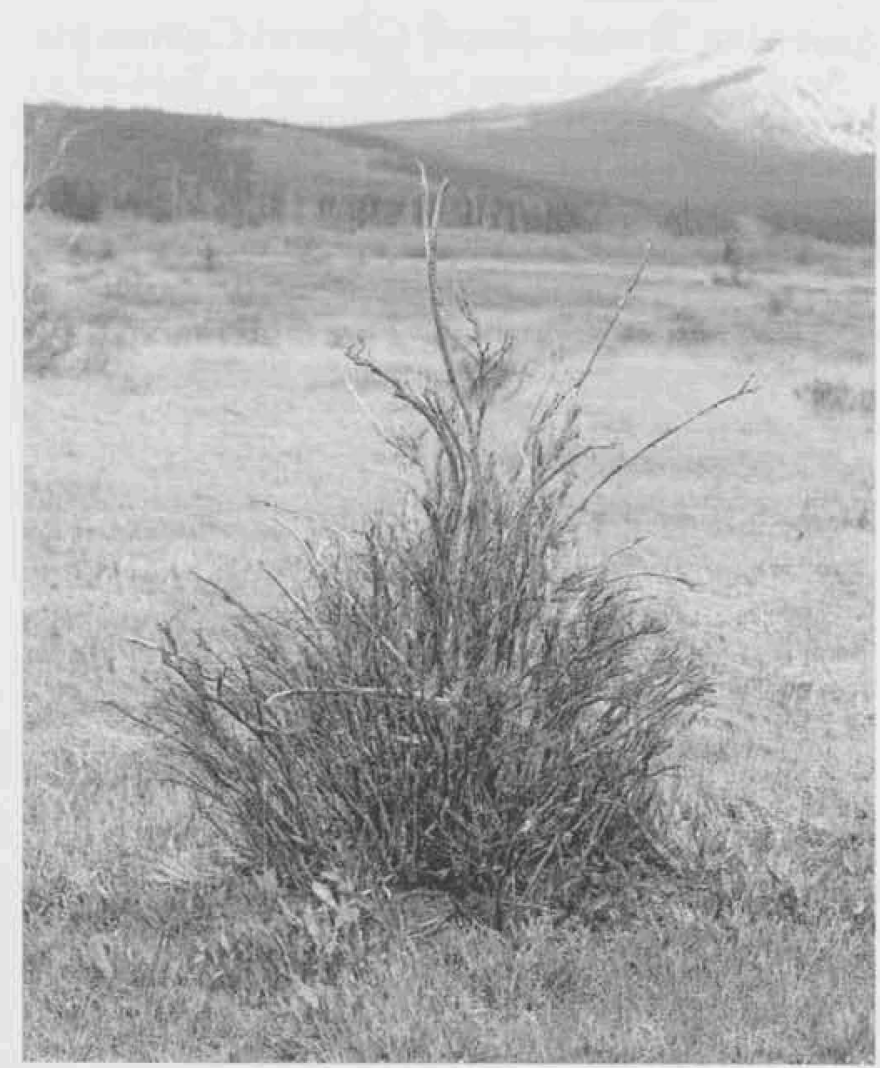

Fig. 3. Heavy browsing produces clusters of twigs at the ends of stems. A substantial portion of this shrub is dead.

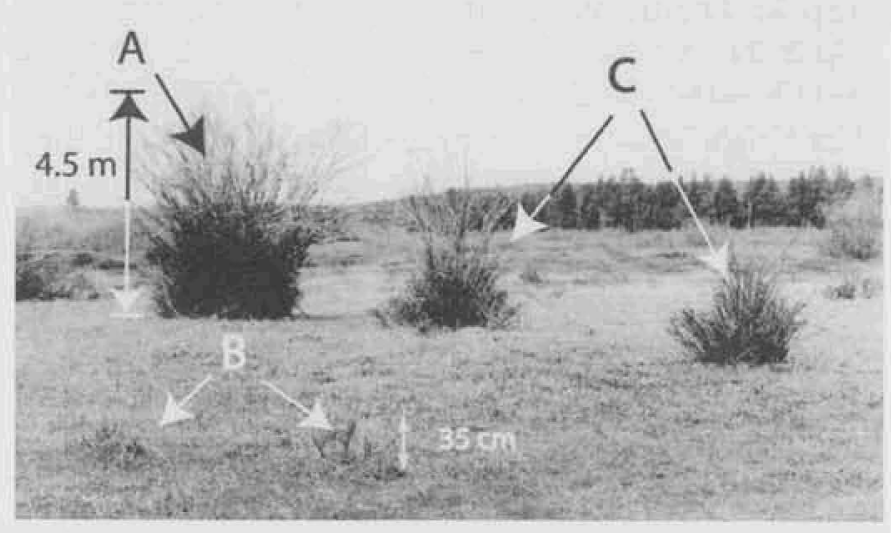

Fig. 4. A qualitative history of browsing can be interpreted by observing the relationship between plant height and plant age. In this case, an increase in browsing pressure has prevented young willows from attaining full stature.

\section{Step 1: Identify relevant management objectives}

The management of the browse resource was linked to area-wide management objectives. Two such objectives were deemed especially important. First, the area was purchased to provide winter range for big game. To serve as winter range, browse plants must be available for ungulate use under snow cover that ranges from negligible early in
Common and scientific names of species.

\section{Wild Ungulates}

moose
American pronghorn antelope
Rocky Mountain elk
Rocky Mountain mule deer
Whitetail deer

Alces alces

Antilocapra americana

Cervus elaphus

Odocoileus hemionus

$O$. virginianus

dogwood

Plants

spruce

Booth willow

Drummond willow

Geyer willow

Planeleaf willow

Scouler willow.

Wolfs

Cornus stolinifera

Picea engelmannii

Salix boothi

S. drummondi

S. geyeriana

S. planifolia

S. scouleriana

S. wolfi

the winter season, to snow that lies more than 3- to 4-feet deep in mid-winter.

In addition, Montana Fish, Wildlife and Parks is committed to providing habitat for a variety of game and nongame wildlife. For example, Mt. Haggin Wildlife Management Area provides nesting habitat for sandhill cranes and neotropical migrants. Accomplishing these management objectives requires the presence of appropriately-sized woody plants.

At Mt. Haggin, willows range in height from very small, young plants, to older plants more than 16 -feet tall. The preservation of this diversity in plant heights is essential to meeting the management objectives. Formally stated, the management objective is: Plants of diverse heights will be present, ranging to the full height potential as determined by local environmental conditions.

Full-statured plant stems (say those that grew to 16-feet tall) have a finite lifespan. If full-statured stems are to persist in a community, young stems must grow to full stature to replace those that die of old age. Heavy browsing can prevent young stems from growing through the browse zone. Continued long enough, heavy browsing can lead to the elimination of entire browse plant communities.

To maintain a plant community of varied heights, browsing must be light enough to allow young stems to grow through the browse zone and attain full stature. We used three methods to examine the fate of stems as they attempted to grow through the browse zone (architecture, stem height, and growth rate). Because full-statured stems are relatively long-lived, it is not necessary that all young stems grow to full stature-just some. Thus we look for evidence that browsing has prevented all young stems from growing tall.

\section{Step 2: Indicator species}

We focused on a single indicator species. That species should have two characteristics. First, it should be among 
those preferred by ungulates. A highly-preferred species (such as dogwood) is a more sensitive indicator of browse impacts than less-preferred species (such as spruce). Second, the indicator plants should be widely distributed across the managed area. From this distribution, managers can determine how browsing level varies across the landscape. We selected Geyer willow as the indicator species.

We assume that the fate of other browse species is indicated by the trend of Geyer willow. If Geyer willow is in decline, the decline of more-highly preferred species would already have occurred. As the amount of available Geyer willow diminishes, less-highly preferred browse species will begin to decline.

\section{Step 3: Delineating the distribution of the in- dicator species}

We prepared a map on which we estimated the total distribution of Geyer willow in the study area (Fig. 5). We

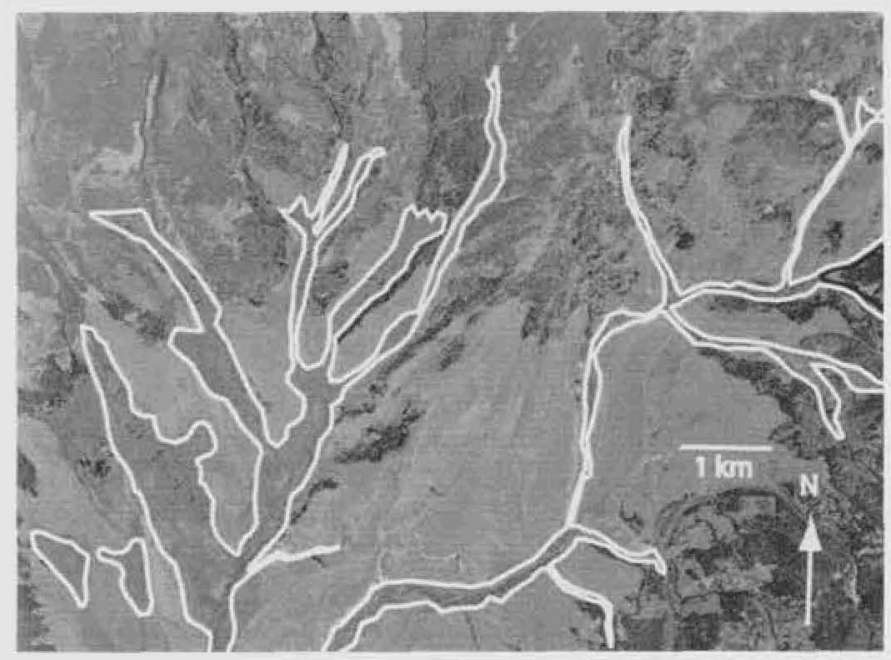

Fig. 5. Map showing distribution of Geyer willow. This map served as the basis for selecting areas for surveying and monitoring.

used the map to prioritize the subsequent steps of field surveying and monitoring. The map was based on a combination of site visits and by examining willow canopy cover on 1:12,000 aerial photographs. From site visits, we determined that Geyer willow extended across the full elevation range included in the study area. This distribution implied that, if any riparian willows were present in an area, Geyer willow plants would likely be included.

Because the map was to be used primarily for prioritizing future work, it was not necessary that the willow community boundaries be precisely drawn. In our case, high quality aerial photographs made the job relatively simple. This step could also be accomplished using images downloaded from the Internet or by delineating the approximate community boundaries on a topographic map.

\section{Assessing Trend-Some General Comments}

Trend was assessed using two approaches: field surveys and monitoring. During surveys, emphasis was placed on rapidly covering a broad geographic area. During monitoring, more-detailed data were collected from fixed locations; those same locations will be resampled periodically.

In the course of assessing trend, three different questions were addressed:

1. In recent years, have plants been able to grow through the browse zone? (This question is addressed in field surveys by examination of plant architectures.)

2. Over the long term, are plants growing taller? (This question is addressed during monitoring by comparing the height of live stems to the height of stems killed by browsing.)

3. Do plant stems grow fast enough to grow out of ungulate reach before they die? (This question was addressed during monitoring by determining stem lifespan and by measurement of growth rate.)

The data collected during surveys and monitoring complement one another; managers can emphasize one type of data over another to suit their needs. If it is most important to determine how browsing level might vary across the landscape, the manager can emphasize the survey component. Alternatively, managers wishing to track short-term changes in browsing impacts can do so with the type of data collected during monitoring.

\section{Step 4: Trend assessment by field surveys}

Field surveys document two aspects: a) browsing level, and b) plant height. Browsing level is an indicator of trend. Plant height indicates the availability of browse during winter. And if the community is in decline, plant height provides a rough indication of persistence; tall willow plants, with some stems out of ungulate reach, appear to live longer than shorter willows in which all terminal leaders are heavily browsed.

Below, we describe two field surveys, one conducted on a segment of Sullivan Creek, the other on a segment of Deep Creek. Both areas contain willows that range in height from very short, young plants (e.g., 8 inches) to older plants that are more than 16-feet tall.

Browsing level. Two levels of browsing are distinguished: a) intense, and b) light-to-moderate. In Keigley and Frisina (1998) we present specific rules for determining if a stem is intensely browsed. Intense browsing occurs when a complete annual segment is killed; current-year-growth develops from a segment older than the previous-year's-growth. Under light-to-moderate browsing, current-year-growth consistently develops from the previous-year's-growth. These rules apply at the stem level.

At the whole-plant level, browsing level affects plant architecture (growth form). We have identified four architec- 


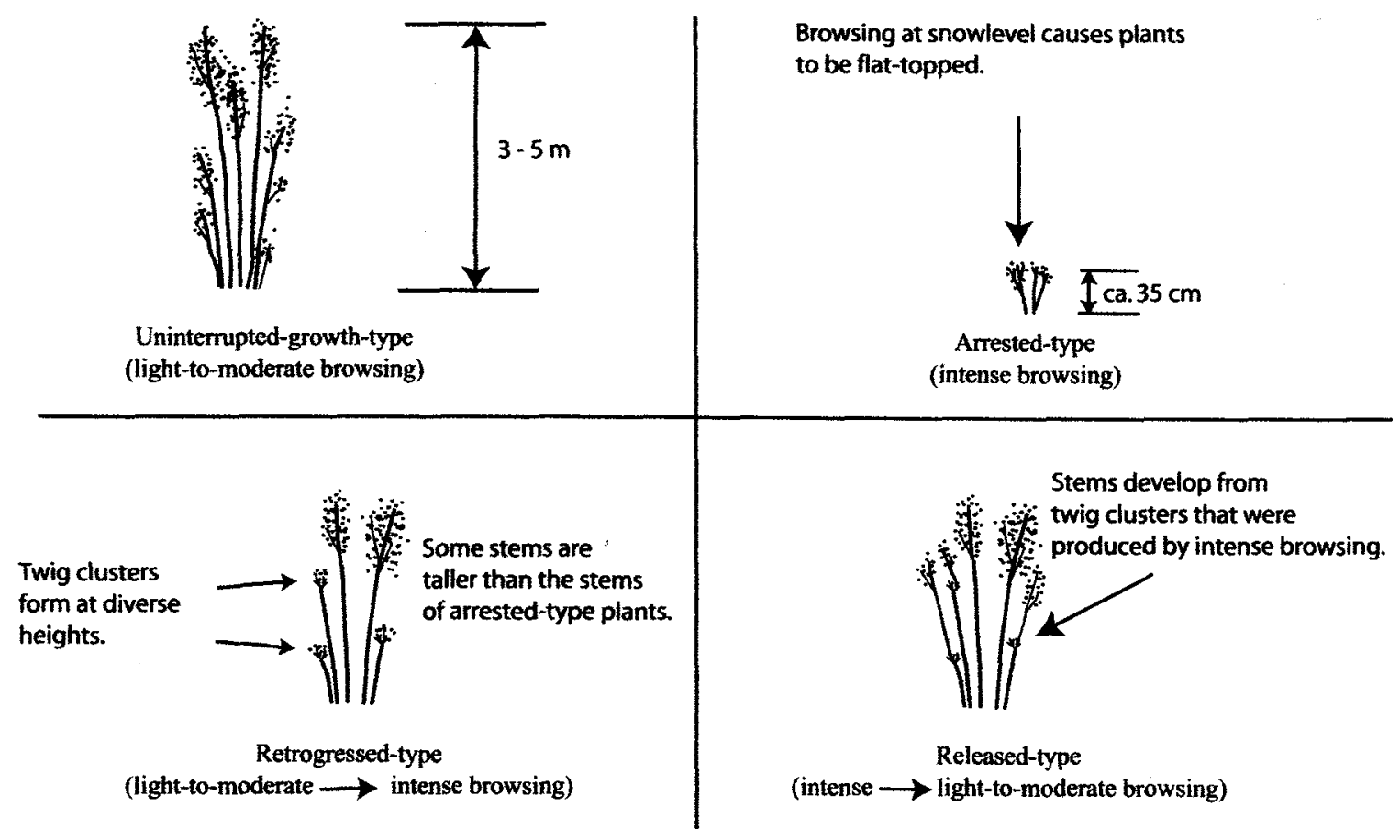

Fig. 6. Browsing-related architectures.

ture-types that correspond to four browsing regimes (Fig. 6 ). The architectures are produced during the period of time that the terminal leader grows within the browse zone. They are:

a) Uninterrupted-growth-type architecture (produced under light-to-moderate browsing conditions),

b) Arrested-type architecture (produced by intense browsing),

c) Retrogressed-type archtecture (produced by a change from light-to-moderate browsing to intense browsing), and

d) Released-type architecture (produced by a change from intense browsing to light-to-moderate browsing).

Because these architectures are mainly produced when the plant is young, one can interpret the browsing history of a site by examining plants of different age.

To assess trend, we examined the architecture of plants with terminal leaders in the browse zone. At Mt. Haggin,

\section{Measurment Units}

Our methods involve relationships between small lengths (stem growth rates that are sometimes less than one inch per year) and large lengths (plant heights greater than 8 feet). Because calculations involving inches and feet are cumbersome, field measurements were made in metric units.

Throughout the text, length measurements are described in English units, with values often rounded to the nearest inch or foot. The measured metric units are presented in parentheses. the browse zone extends from a lower limit of about 8 inches $(20 \mathrm{~cm})$ above ground level to an upper limit of about 8 feet $(2.5 \mathrm{~m})$. Plants are apparently browsed at 8 inches early in the winter season as snow begins to accumulate. The upper limit of the browse zone is controlled by ungulate reach. Stems greater than about 5 feet $(1.5 \mathrm{~m})$ may be out of direct reach of deer and livestock; elk and moose can reach upwards of 8 feet $(2.5 \mathrm{~m})$. Browsing at heights greater than those upper limits can occur when ungulates stand on crusted snow, stand on hind legs, or bend stems to the ground.

We characterized the level of browsing by examining the architecture of plants in which the base of the terminal leader was between 30 and 60 inches $(75-150 \mathrm{~cm})$ tall. Plants in this height range likely were exposed to browsing during recent winters.

We distinguished between two situations: a) all plants exposed to browsing have arrested- or retrogressed-type architecture (mapping unit: "100\% intensely browsed"), and b) some plants exposed to browsing have uninterrupted-growthor released-type architecture (mapping unit: " $<100 \%$ intensely browsed"). In the case where all plants have arrested- or retrogressed-type architecture, it is probable that no young plants will attain their potential height. In the second case, some plants apparently will attain full stature, and the desired condition will be maintained or attained.

As we traversed the field survey area, we delineated the willow area on an aerial photograph. We partitioned that area into the two mapping units described above. As we moved through an area, we sought out plants that might have uninterrupted-growth- or released-type architecture. 
When such plants were found, we tried to determine why they had escaped browsing. If a plant was deemed to have escaped browsing because of local protection, we discounted the architecture of that plant as an indicator of area-wide browsing pressure. Local protection of a young plant might occur when a taller neighbor inhibits ungulate access, either directly or by creating a deep snowdrift. When these circumstances were confined to a few square meters, we assumed that the protective effect was temporary.

Plant height. Plant height was documented by narrative description in the Sullivan Creek survey and by mapping in the Deep Creek survey. In the Sullivan Creek survey, we described the general circumstances under which willows greater than 10-feet (3-m) tall were found.

In the Deep Creek survey, we distinguished between three plant-height categories: a) Short (the plant is $<20$-inches $(50-\mathrm{cm})$ tall, symbolized by "S"), b) Intermediate (between 20 -inches $(50-\mathrm{cm})$ and 9.8 -feet $(3-\mathrm{m})$ tall, symbolized by "I"), and Tall (> 9.8-feet (3-m tall), symbolized by "T"). Plant-community height characteristics were described using combinations of the three categories: S, I, T, SI, ST, IT, and SIT. For example, a community composed of willows less than 20 -inches $(50-\mathrm{cm})$ tall and willows greater than 9.8 -feet $(3-\mathrm{m})$ tall would be designated ST. A site that has experienced protracted intense browsing may be composed entirely of plants in the S category. During the winter, plants in the S category often are buried by snow and unavailable to ungulates. Plants in the $\mathrm{I}$ and $\mathrm{T}$ categories are a source of browse under diverse snow cover conditions.

Category $\mathrm{T}$ was distinguished because stems greater than $3-m$ tall often escape browsing. The presence of tall terminal leaders might allow a shrub to persist longer than shrubs that solely consist of shorter terminal leaders that are all heavily browsed. As in the mapping of browsing level, the total willow area was delineated on an aerial photograph and partitioned-as we traveled across the areainto the 7 mapping units listed above.

Deep Creek field survey. The surveyed segment was about 0.6 miles $(1 \mathrm{~km})$ long; willow covered 270 acres (110 ha) (Fig. 7). The entire area was classified as $100 \%$ intensely browsed. As above, the few uninterrupted-growth type plants were growing in vicinity of taller, heavily browsed, neighbors. We assumed the mechanical protection was temporary.

Stands that included willows greater than 9.8-feet (3-m) tall constituted $33 \%$ of the total willow area of 89 acres ( 36 ha) (Fig. 8). The remainder of the area (i.e., 67\%) consisted of willows that ranged in height from ca. 8 inches to 8 feet $(20-250 \mathrm{~cm})$ tall. While we currently have no basis for quantitatively predicting the rate of decline, we do know that $67 \%$ of the willow area is susceptible to a relatively rapid rate of decline.

Sullivan Creek field survey. The surveyed segment of Sullivan Creek was about 2.2 miles $(3.5 \mathrm{~km})$ long; willow

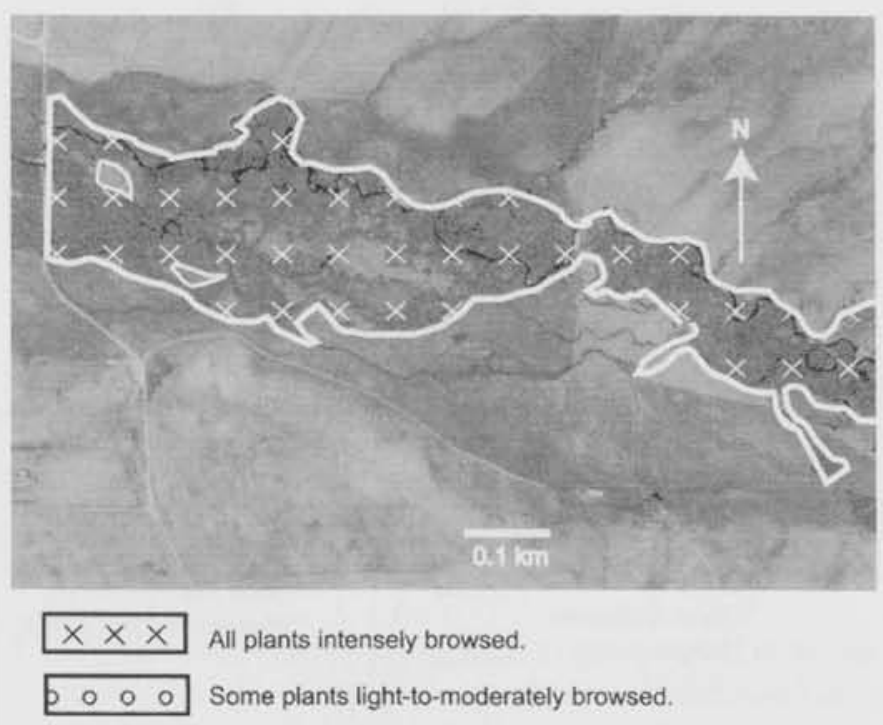

Fig. 7. Browsing intensity on Deep Creek segment of field survey. The entire area was $100 \%$ intensely browsed.

covered 570 acres (230 ha) (Fig. 9). The entire area was classified as $100 \%$ intensely browsed. Uninterruptedgrowth-type plants were uncommon. In each case, we could identify how the plant was mechanically protected from browsing. If current browsing pressure continues, the protection will be temporary. As the plants adjacent to the uninterrupted-growth-type plants die, moose will focus on the remaining live plants.

Willows greater than 9.8 feet $(3 \mathrm{~m})$ tall grow in linear zones along current and relict watercourses. Linear zones of tall willows are also associated with beaver dams. Many of the ponds have drained, allowing willows to become established there; these willows range in height from about 8 inches to 7 feet $(20-200 \mathrm{~cm})$ tall. Willows could have become established on the beaver dams when the ponds were still filled with water, so in part, willows growing on the dams may be taller because they are older than willows growing on the former pond areas. In part, the difference in

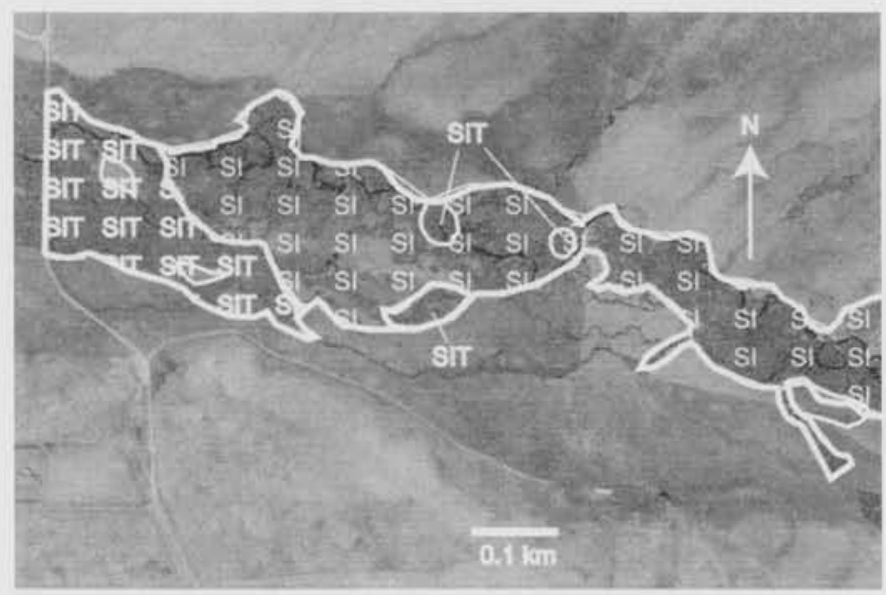

Fig. 8. Willow height at Deep Creek segment. 

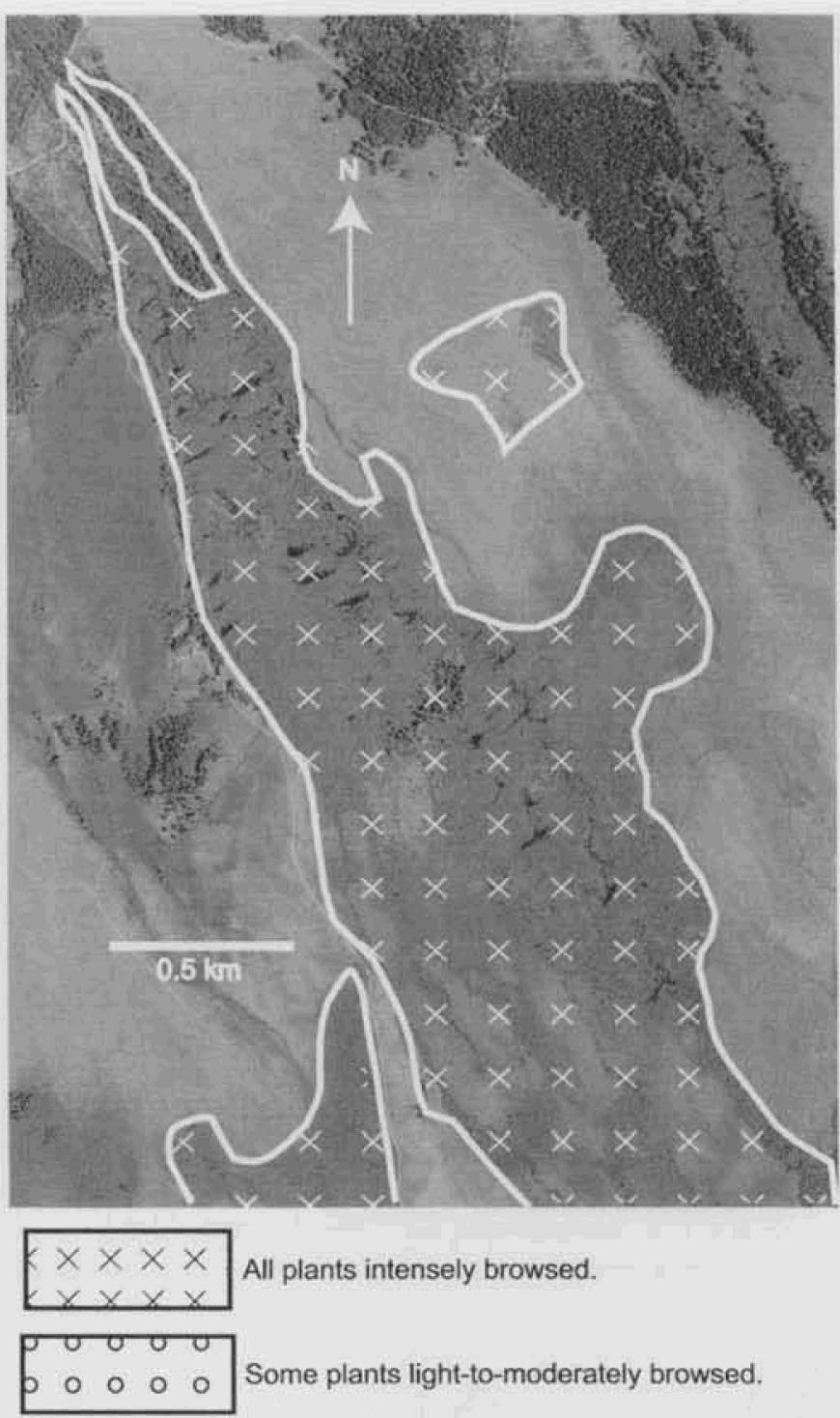

Fig, 9. Browsing intensity on Sullivan Creek segment of field survey. The entire area was $100 \%$ intensely browsed.

height might be due to heavier browsing of willows growing in the pond areas. A dendrochronologic analysis of stems indicates that browsing pressure increased in the mid-1980s. Willows established since the 1980s would have experienced intense browsing while the tallest terminal leaders were within the browse zone. There is extensive mortality of shorter willows.

\section{Summary of Part 1}

We described above how plant architectures can be used to assess browse trend across large geographic areas. However, the statistical analysis of the architecture data is limited. In Part 2 of this paper we describe how browse trend was further assessed using quantitative data that were periodically collected at fixed sites. We refer to that phase of trend assessment as "monitoring."
About the authors: Richard B. Keigley, Ecologist, U.S. Geological Survey, Biological Resources Division, 632 Coulee Drive, Bozeman, MT 59718. Michael R. Frisina, Range Coordinator, Montana Fish, Wildlife, \& Parks, Butte, MT, 59701-2112. Craig W. Fager, Wildlife Biologist, Montana Fish, Wildlife \& Parks, 1820 Meadowlark Lane, Butte, MT, 59701

Acknowledgements: The study was funded by Montana Fish Wildlife\& Parks and by the United States Geological Survey. This paper was peer reviewed. The authors thank Dick Jachowski, Steve Knapp and Kriss Douglass for reviewing an early draft, and thank an anonymous reviewer.

\section{References}

Aldous, C.M. 1945. A winter study of mule deer in Nevada. J. of Wildlife Manage. 9:145-151.

Dasmann, W.P. 1951. Some deer range survey methods. California Fish and Game. 37:43-52.

Frisina, M. R. 1992. Elk habitat use within a rest-rotation grazing system. Rangelands 14(2):93-96.

Julander, O. 1937. Utilization of browse by wildlife. Transactions $2^{\text {nd }}$ North American Wildlife Conference. pp. 277-285.

Keigley, R.B. 1997a. A growth form method for describing browse condition. Rangelands. 19:26-29.

Keigley, R.B. 1997b.. An increase in herbivory of cottonwood in Yellowstone National Park. Northwest Science. 71:127-136.

Keigley, R.B. 1998. Architecture of cottonwood as an index of browsing history in Yellowstone. Intermountain Journal of Sciences, 4:57-67.

Keigley, R.B. and M. R. Frisina 1998. Browse evaluation by analysis of growth form. Montana Fish Wildlife \& Parks. 153 pp.

Nelson, E.W. 1930. Methods of studying shrubby plants in relation to grazing. Ecology. 11:764-767.

Stickney, P.F. 1966. Browse utilization based on percentage of twigs browsed. J. of Wildlife Manage. 27:76-78. 


\title{
Assessing Browse Trend at the Landscape Level Part 2: Monitoring
}

\author{
By Richard B. Keigley, Michael R. Frisina, and Craig W. Fager
}

I

n Part 1 (see page 28), we assessed browse trend across a wide geographic area of Mt. Haggin Wildlife Management Area by conducting surveys of browsingrelated architectures. Those data were qualitative. Below we describe the periodic collection of quantitative data from permanently marked locations; we refer to this phase of the trend assessment program as "monitoring." Trend was monitored by three methods:

1. Repeat photography.

2. Comparison of the height of live stems with the height of stems killed by browsing (LD Index).

3. Net annual stem growth rate $\left(\mathrm{NAGR}_{\mathrm{L} 3}\right)$.

The photography provides an assessment of trend from the comparison of photographs taken at intervals of a few years. The LD Index and $\mathrm{NAGR}_{\mathrm{L} 3}$ measurements provide an immediate assessment of trend.

Establishment of permanent stations. Three considerations entered into the location of monitoring stations. Based on observation of moose habits, the stations were located in areas heavily used by moose. The stations were dispersed across the area in which Geyer willow occurs. The sites are accessible with relatively little effort.

Each station's location was documented in 6 ways: a) small-scale map, b) narrative description, c) large-scale sketch map, d) GPS coordinates, e) photographs of surrounding area, and f) a steel fence post. The small-scale map and narrative description should locate the station to within about a hundred meters. The large-scale sketch map, GPS coordinates, and area photographs should lead a person directly to the steel post.

Four monitoring stations were established in 2000 (Fig. 1). Stations MS1 and MS2 are located in areas where field surveys were conducted (Sullivan Creek and Deep Creek). Station MS2 is located in a 30 ha fenced area from which cattle have been excluded since the mid-1980s; browsing effects at this station are unequivocally due to wildlife. Stations MS3 and MS4 are respectively located in the French and American Creek drainages.

Transect for repeat photography. Two kinds of photographs were taken: a) a panoramic series, and b) a photograph down a permanent transect line (Fig. 2). When taking the transect photo, the camera was positioned above the steel stake. The transect bearing was recorded on the sketch map. A metric tape was extended down the transect line. A

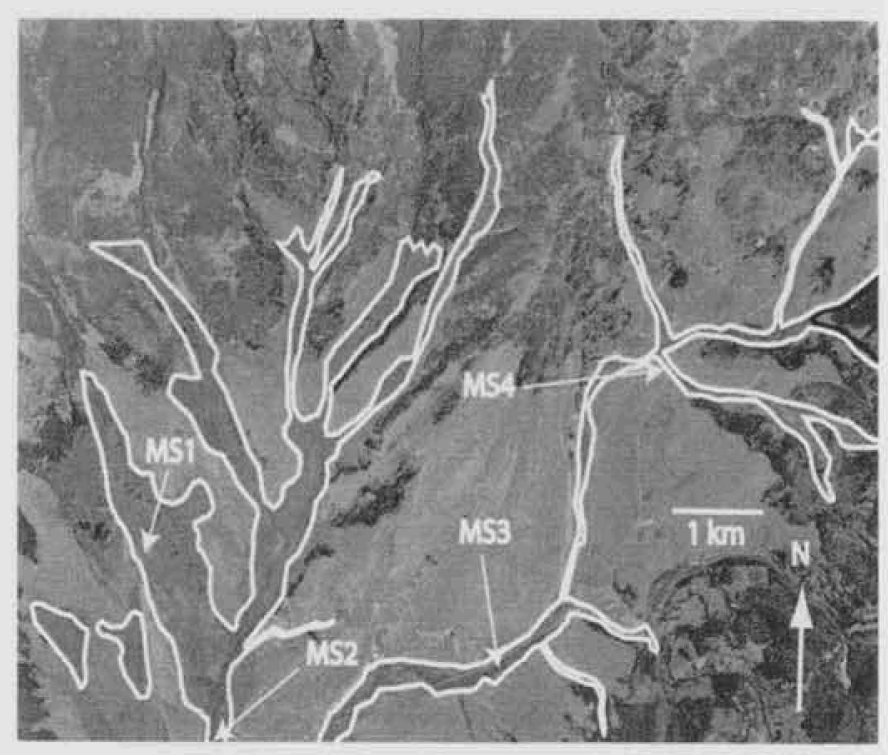

Fig. 1. Location of monitoring stations.

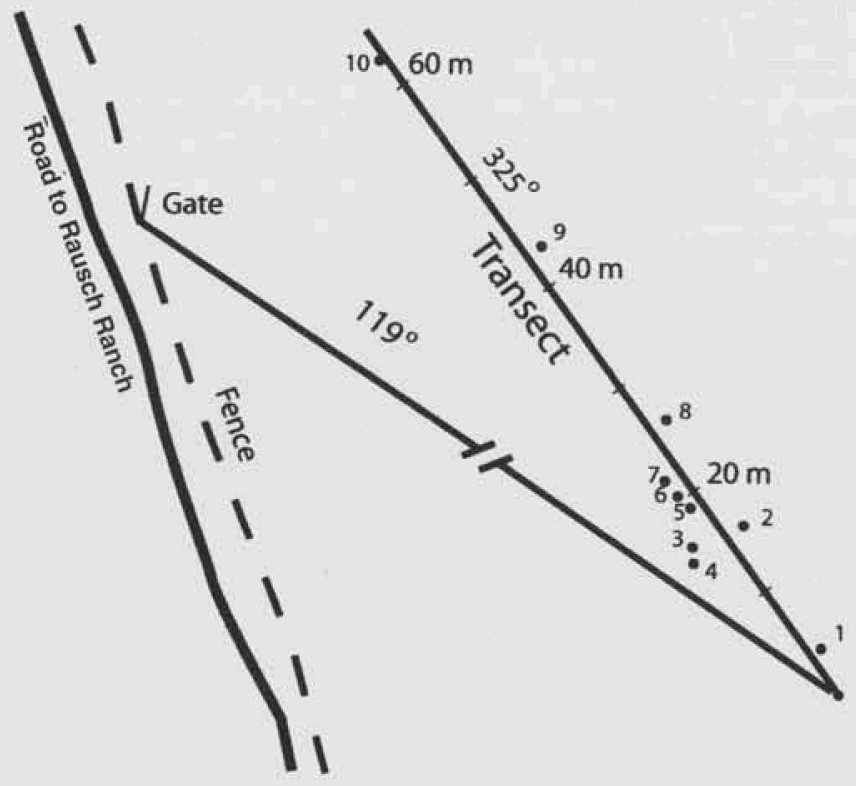

Fig. 2. Sketch map of transect at monitoring station 1. 


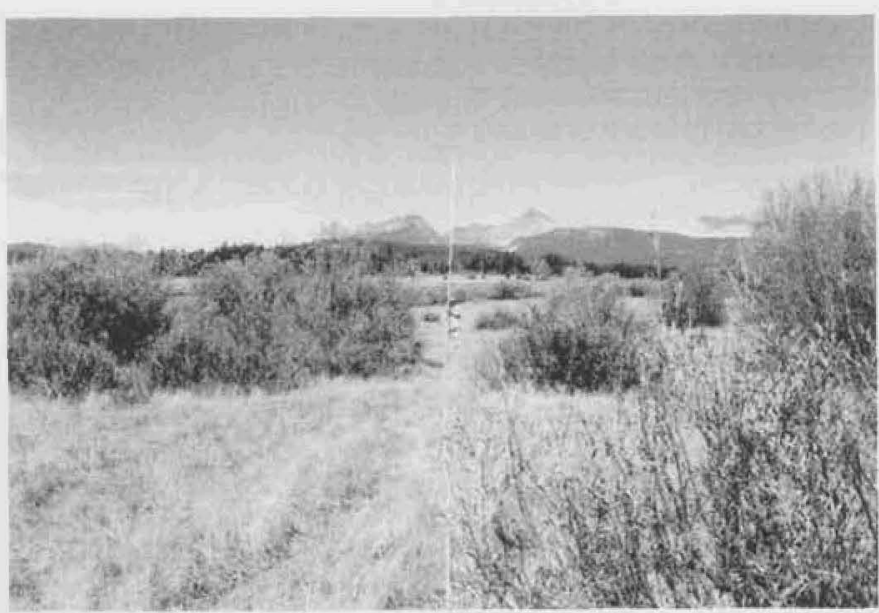

Fig. 3. Photograph down transect at monitoring station 1 .

metric stadia rod was included for scale; the location of the stadia rod was recorded on the sketch map.

Along the transect line, the location of 10 Geyer willow plants was documented by recording their distance along the transect line and their offset (N/S or E/W) from that line. Two heights were recorded for each plant: a) the height to the base of the tallest current-year-growth $\left(\mathrm{H}_{\mathrm{pyg}}\right)$, and b) the height to the tip of the tallest stem killed by browsing $\left(\mathrm{H}_{\mathrm{D}}\right)$.

A typical transect photograph is shown in Fig. 3. While photographs provide tangible evidence of plant condition, their interpretation is subjective. By documenting the location and measurement of 10 plants, we provide future viewers a limited quantitative perspective. The effect of browsing often is difficult to see in photographs that are

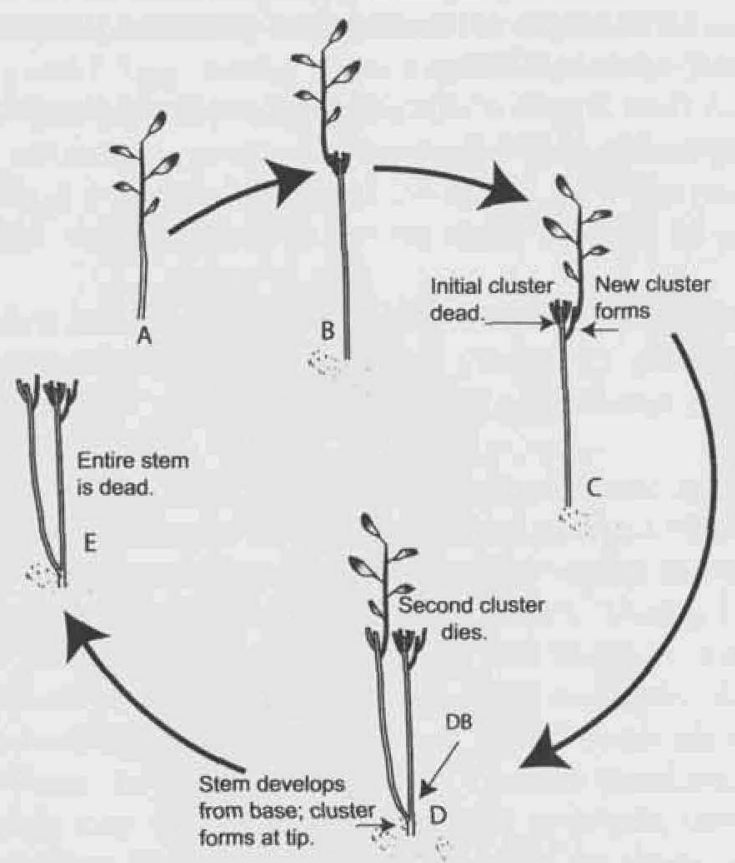

Fig. 4. Sequence of growth and death of a heavily-browsed stem. taken late in the growing season when current-year-growth extends well beyond the twig clusters.

Trend assessment based on LD Index. This index expresses the difference between the height of live stems and the height of stems killed by browsing. The index was based on the following observations. Willow shrubs with dead stems are common throughout Mt. Haggin Wildlife Management Area. Such shrubs are typically composed of stems of different age as represented by the types shown in sequence AE (Fig. 4). From establishment to death, a typical stem progresses through the following history. Stems are light-tomoderately browsed until they grow above snowcover or above other forms of mechanical protection (A).

Once the stem is available to ungulates, browsing causes clusters of twigs to form at the tip (B in Fig 4). After a period of time, the cluster-bearing portion of the stem dies, and one or more lateral branches develop from a lower position on the stem; these branches assume the role of terminal leader. The lateral branches might develop at the base of the original cluster (C), or may develop at the base of the original stem (D). Clusters of twigs form on the new terminal leader, and after a period, the new terminal leaders die. Finally, the entire above-ground portion of the stem dies (E).

The LD Index monitoring method is based on the difference in the height of stems killed by browsing versus the height of live stems. Where there are both live and dead stems present, there are three possible relationships:

a) Live and dead stems may be at the same height,

b) Live stems may be below the height of the dead stems, and

c) Live stems may be taller than the dead stems.

The relationships would be produced as follows: The dead clusters of twigs form a zone of mechanical protection. The young stems that develop from the base of the shrub are typically not browsed until they extend beyond the dead stems. Once live stems extend above that mechanical protection, browsing begins and a new cluster of twigs develops. Under these circumstances, the base of currentyear-growth is about the same height as the dead cluster of twigs (C and D).

As browsing pressure continues and the vigor of the shrub diminishes, the base of the current-year's-growth may fall below the level of the dead stems. Alternatively, if a plant is protected from browsing, the base of currentyear's-growth will progressively grow above the height of the stems killed by browsing. These height relationships form the basis of one method of assessing trend during monitoring.

Stems from 20 plants were selected for measurement based on height and vigor. To meet the height criterion, the base of current-year-growth of the tallest stem had to be within the zone $75-200 \mathrm{~cm}$ above the ground. Stems in this region are exposed to browsing. Shorter plants were measured when necessary. 
Table. 1. LD Index. This index applies to plants in which some stems have been killed by browsing. Values greater than zero indicate that the live stems have grown taller than the stems killed by browsing. Values near zero indicate that the stem is browsed at about the same level as the dead stems (dead stems provide mechanical protection from browsing). Values less than zero indicate that the plant is dying back to ground level.

\begin{tabular}{cccc}
\hline \hline Monitoring station & LD Index $\pm \mathrm{SE}$ & Maximum value & Minimum value \\
\hline \multirow{4}{*}{ inches } & inches & inches \\
1 & $(\mathrm{~cm})$ & $(\mathrm{cm})$ & $(\mathrm{cm})$ \\
& $-4.8 \pm 2.1$ & 11.4 & -26.8 \\
2 & $(-12.3 \pm 5.4)$ & $(29)$ & $(-68)$ \\
& $-15.1 \pm 3.9$ & 0 & $(-61.0)$ \\
3 & $(-38.3 \pm 10.0)$ & $(0)$ & $(-15)$ \\
& $-3.3 \pm 1.4$ & 5.1 & -19.3 \\
4 & $(-8.5 \pm 3.5)$ & $(13)$ & $(-49)$ \\
& $0.7 \pm 2.2$ & 22.8 & -12.2 \\
& $(1.7 \pm 5.5)$ & $(58)$ & $(-31)$ \\
\hline
\end{tabular}

Of plants meeting the height criterion, the most vigorous were selected for measurement. The reasoning was as follows. For the full-statured community to persist, tall plants must be replaced as they die. The tall plants are relatively long-lived, so only a few young individuals must grow to full stature. For that reason, we biased sampling to include those plants that most likely would succeed. Plants were not marked for remeasurement in subsequent years; each year's sample is based on a new selection that might or might not include plants measured in previous years.

The height of the tallest stem was measured to the base of current-year-growth $\left(\mathrm{H}_{\mathrm{pyg}}\right)$. Stems killed by browsing were identified by bite marks and clusters of twigs. Height was measured to the tip of the dead stem $\left(\mathrm{H}_{\mathrm{D}}\right)$. The LD Index was calculated from: $\mathrm{H}_{\mathrm{pyg}}-\mathrm{H}_{\mathrm{D}}$. Values near zero indicate that browsing limits current-year-growth to the zone of mechanical protection. Negative values indicate that the community is in significant decline. Positive values indicate recovery.

The LD Index data indicate that Geyer willow is in decline at all monitoring sites; most current-year-growth that extends above the limit of mechanical protection is consumed during the winter (Table. 1).

At MS1, MS2, and MS3, the mean LD Index was less than zero, while the mean LD Index of 1.7 at MS4 was very close to zero. Out of the entire sample set of 80 stems, only 16 had LD Index values greater than 0,9 of which were at MS4. The maximum LD Index value encountered was $58 \mathrm{~cm}$; this stem was at MS4. The low LD Index values confirm what can be seen with the eye during the growing season. From a distance, many willow stands are brownish in color; stems with leaves are obscured by taller dead stems.

Trend assessment based on NAGR $_{\mathbf{L}_{3}}$. The second of the two monitoring methods is based on the minimum growth rate that will enable a stem to grow out of ungulate reach before it dies. Dead stems, such as those seen in Fig. 3, Part 1 (p. 29) above, are evidence that browsing can kill. It fol- lows that heavily browsed stems have a limited period to grow out of reach. We determined the lifespan of heavily browsed stems by taking sections of dead stems (presumed to have been killed by browsing) and counting the number of annual rings. Most sections were taken from the region labeled DB in the figure above (Type D). The average age at death was $10.2 \pm 0.3$ years $( \pm$ $\mathrm{SE}, \mathrm{N}=116$, unpublished data).

We established a threshold $\mathrm{NAGR}_{\mathrm{L} 3}$ value as follows. If a stem does not grow tall enough to escape browsing within about 10 years, dieback will occur. We used $2.5 \mathrm{~m}$ as the height of escape. To grow $2.5 \mathrm{~m}$ in 10 years, the stems must grow an average of 25 $\mathrm{cm}$ per year. Where other species are monitored at other locations, a corresponding stem lifespan and threshold growth rate would have to be determined.

The stems selected for LD Index measurement were also used for NAGR $\mathrm{L}_{3}$ measurements. The following data were collected from each stem:

1. Lcyg (length of current-year-growth). In this example, assume that the data were collected in August 2000. The current-year-growth segment would have been produced the same growing season, that is, in 2000 (Fig. 5).

2. L1 (live length of the segment produced the previous year-i.e., in 1999.

3. L2 (live length of the segment produced the previous year-i.e., in 1998)

4. L3 (live length of the segment produced the previous year-i.e., in 1997)

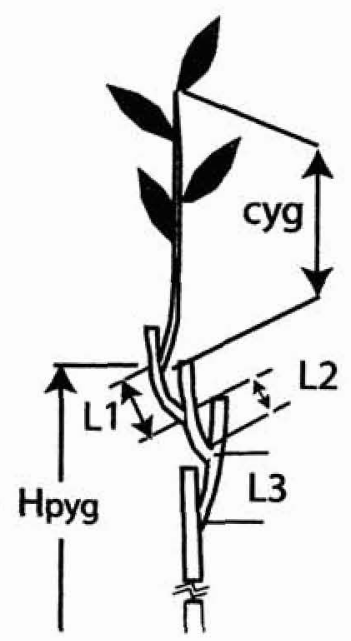

Fig. 5. Segments measured for LD Index. 
Table. 2. Net Annual Growth Rate (NAGR) based on the average stem length added during the previous three growing seasons. At Mt. Haggin, browsed stems have an average lifespan of about 10 years. To grow out of ungulate reach before they die, stems must have a Net Annual Growth Rate of about 10 inches $(25 \mathrm{~cm})$ per year or greater.

\begin{tabular}{cccc}
\hline \hline Monitoring station & NAGR $_{\mathrm{L} 3} \pm \mathrm{SE}$ & Maximum value & Minimum value \\
\hline & inches & inches & inches \\
& $(\mathrm{cm})$ & $(\mathrm{cm})$ & $(\mathrm{cm})$ \\
1 & $4.4 \pm 1.0$ & 20.4 & 0.5 \\
& $(11.2 \pm 2.5)$ & $(51.7)$ & $(1.3)$ \\
2 & $3.3 \pm 0.6$ & 11.3 & 0.7 \\
& $(8.5 \pm 1.5)$ & $(28.7)$ & $(1.7)$ \\
3 & $3.9 \pm 0.6$ & 9.4 & 1.1 \\
& $(9.9 \pm 1.5)$ & $(24.0)$ & $(2.7)$ \\
4 & $5.6 \pm 0.9$ & 13.5 & 0.8 \\
& $(14.2 \pm 2.4)$ & $(34.3)$ & $(2.0)$ \\
\hline
\end{tabular}

The growing season years were determined by inspection of terminal bud scars. If a complete annual increment died, the length for that year would be entered as zero. For example, if the segment produced in 1998 died, the 1999 segment might develop from the 1997 segment. The remains of the 1998 segment would be identifiable from terminal bud scar relationships. Because the 1998 segment did not contribute to live stem length, its value - with respect to growth rate-is zero.

Because monitoring data will be collected each year, we need to be able to distinguish between data collected in different years. A two-part nomenclature is used. The first part refers to the segment type (Lcyg, L1, L2, or L3); the second part, written as a subscript, refers to the year in which the data were collected. For example, $\mathrm{L1}_{2000}$ refers to an $\mathrm{L} 1$ segment that was measured in 2000 .

Growth that occurred during a single year can be tracked over a subsequent three-year period. For example, $\mathrm{L1}_{2001}$, $\mathrm{L} 22_{2002}$ and L $3_{2003}$ would all be expressions of the fate of current year growth produced in 2000 .

The net annual growth rate for the preceding three years $\left(\mathrm{NAGR}_{\mathrm{L} 3}\right)$ was calculated by $(\mathrm{L} 1+\mathrm{L} 2+\mathrm{L} 3) / 3$. The resulting value was compared to the threshold value of $25 \mathrm{~cm} /$ year.

Mean $\mathrm{NAGR}_{\mathrm{L} 3}$ values for all four sites were well below the threshold value of $25 \mathrm{~cm} /$ year (Table. 2). Of the 80 stems sampled, only 7 exceeded the threshold value; 5 of these were at MS4.

The NAGR $\mathrm{L}_{3}$ method of measuring growth rate is rapid and nondestructive. However, there are sources of error that should be considered. Under heavy browsing pressure, stems undergo cycles of growth and dieback. During periods of dieback, some stem segments will likely be within the protective zone of dead stems. Such stems will have larger $\mathrm{NAGR}_{\mathrm{L} 3}$ values compared to stems where all segments were exposed to browsing. Factors unrelated to browsing may reduce growth rate. For example, current year growth values in drought years might be lower compared to values in moist years.
Browsing may inhibit height growth in three ways. Firstand most obvious-consumption removes material that would otherwise have contributed to height. Second, browsing-induced stress may reduce growth potential. Third, browsing may inhibit height growth by running out the stem's biological clock. Young stems elongate rapidly when they are young, and slow down as they mature. Because intensely browsed stems undergo cycles of dieback, a 1-m-tall stem might be 10-20 years old at the base. On such stems, we have observed that current-year-growth is sometimes only a few $\mathrm{cm}$ in length. Such stems might have entered into an age-related phase of reduced growth.

\section{Summary Of Trend}

The surveys and monitoring conducted at Mt. Haggin Wildlife Management Area in 2000 indicate that Geyer willow is in decline. During the field surveys, no individuals exposed to browsing were found to have uninterruptedgrowth- or released-type architectures. During monitoring, we sampled the most vigorous plants. The LD Index data indicate that current-year-growth is browsed back to the level of mechanical protection. The preponderance of negative LD Index values indicates that major dieback has already occurred. The site-wide average $\mathrm{NAGR}_{\mathrm{L} 3}$ values are well below the threshold value of $25 \mathrm{~cm} /$ year.

The quantity of available browse will diminish as dieback progresses. If the moose population remains approximately constant, increased pressure will be placed on the remaining browse plants. All lines of evidence indicate that, if present trends continue, the willow community will likely be converted to a meadow. To reduce browsing pressure, the moose harvest quota was increased by $50 \%$ for the 2000 hunting season. During the winter of 2000/2001, snow depth was markedly less compared to typical years. The reduced snow pack allowed moose to disperse over a broader area compared to years in which snow is uniformly deeper. These factors are expected to influence willow growth. To document that response, we will conduct surveys and monitoring on an annual basis.

About the authors: Richard B. Keigley, Ecologist, U. S. Geological Survey, Biological Resources Division, 632 Coulee Drive, Bozeman, MT 59718. Michael R. Frisina, Range Coordinator, Montana Fish, Wildlife, \& Parks, Butte, MT, 59701-2112. Craig W. Fager, Wildlife Biologist, Montana Fish, Wildlife \& Parks, 1820 Meadowlark Lane, Butte, MT, 59701 
Acknowledgements: The study was funded by Montana Fish Wildlife\& Parks and by the United States Geological Survey. This paper was peer reviewed. The authors thank Dick Jachowski, Steve Knapp and Kriss Douglass and an anonymous reviewer for reviewing an early draft.

\section{References}

Aldous, C.M. 1945. A winter study of mule deer in Nevada. J. Wildlife Manage. 9:145-151.

Dasmann, W.P. 1951. Some deer range survey methods. California Fish and Game. 37:43-52.

Frisina, M. R. 1992. Elk habitat use within a rest-rotation grazing system. Rangelands 14(2):93-96.
Julander, O. 1937. Utilization of browse by wildlife. Transactions $2^{\text {nd }}$ North American Wildlife Conference. pp. $277-285$.

Keigley, R.B. 1997a. A growth form method for describing browse condition. Rangelands. 19:26-29.

Keigley, R.B. 1997b. An increase in herbivory of cottonwood in Yellowstone National Park. Northwest Science. 71:127-136.

Keigley, R.B. 1998. Architecture of cottonwood as an index of browsing history in Yellowstone. Intermountain J. Sciences. 4:57-67.

Keigley, R.B. and M.R. Frisina. 1998. Browse evaluation by analysis of growth form. Montana Fish Wildlife \& Parks. 153 pp.

Nelson, E.W. 1930. Methods of studying shrubby plants in relation to grazing. Ecology. 11:764-767.

Stickney, P.F. 1966. Browse utilization based on percentage of twigs browsed. J. Wildlife Manage. 27:76-78.

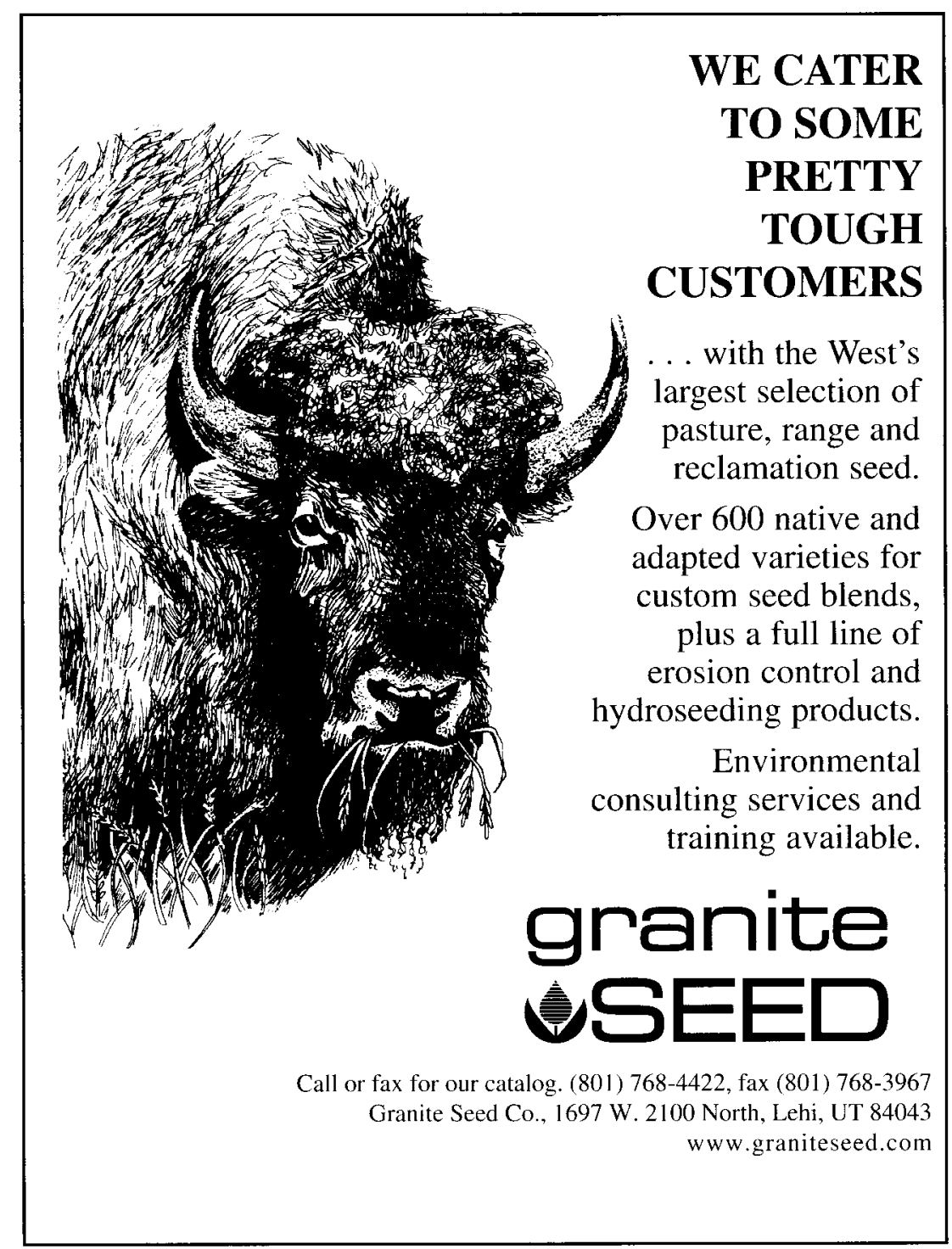




\section{Sneek A Peek At The Upcoming Issue Of The Journal Of Range Management}

\section{Plains Larkspur Grazing By Cattle In Wyoming}

James A. Pfister, Dale R. Gardner, Bryan L. Stegelmeier, Anthony P. Knight, James W. Waggoner, Jr, and Jeffery O. Hall

Plains larkspur is a major cause of cattle deaths in the northern Great Plains of Wyoming and Colorado. The amount and timing of larkspur ingestion by grazing cattle in relation to plant phenology and weather conditions was evaluated at 2 locations in southwestern Wyoming. Results showed it is difficult to predict larkspur consumption based on plant growth patterns or weather. Cattle sometimes increase larkspur consumption when temperatures are cooler than normal but this pattern can not be used as a basis for management recommendations.

\section{Short-Term Monitoring Of Rangeland Forage Conditions With A VHRR Imagery}

David P. Thoma, Derek W. Bailey, Daniel S, Long, Gerald A. Nielsen. Mari P. Henry, Meagan C. Breneman and Clifford Montagne

Ground based methods are not practical for assessing short-term temporal fluctuations in forage quality and quantity over extensive geographic areas. Forage biomass and nitrogen concentration were estimated at 6 sites in Montana using Normalized Difference Vegetation Index (NDVI) from Advanced Very High Resolution Radiometer imagery. The NDVI was a good predictor of forage abundance but was poor in estimating forage quality. The technique may be used to identify areas where drought, variable precipitation patterns, or uneven grazing affected forage abundance.

\section{Sediment Movement And Filtration In A Riparian Meadow Following Cattle Use}

R.R. McEldowny, M. Flenniken, G.W. Frasier, M.J. Trlica, and W.C. Leininger

Improper livestock grazing may reduce the nutrient and pollutant removal function in riparian areas resulting in degradation of surface water quality. A rainfall simulator study in a montane riparian meadow in northem Colorado evaluated the impact of short-duration, high-intensity cattle grazing on sediment movement and filtration. Stem density was reduced $40 \%$ by cattle grazing and was the most important variable affecting sediment filtration. Monitoring stem density should aid land managers in regulating cattle use of riparian communities.
Shrub Control And Streamfiow On Rangelands: A Process-Based Viewpoint

\section{Bradford P. Wilcox}

Shrub control is often cited as a means by which to increase available water for water limited semiarid landscapes. Although research is limited, there is enough information to make some educated guesses about where shrub control has the greatest chance for increasing streamflow. Greatest opportunities for increasing water yield from non riparian rangelands would be on areas that have natural spring flow. For other semiarid areas, shrub control will have little if any impact on streamflow.

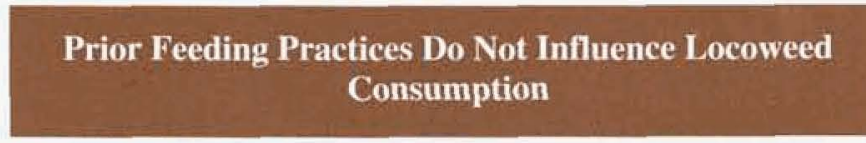

M.H. Ralphs, G. Greathouse, A.P. Knight, D. Doherty, J.D. Graham, B.L. Stegelmeier, and L.F. James

Anecdotal evidence suggests that cattle fed alfalfa hay during the winter are inclined to graze locoweed on spring range. Cattle fed alfalfa during the winter did not consume more locoweed in the spring and early summer than cattle fed grass hay. Other preconditioning feeding practices (such as grazing winter wheat or mineral supplements) have not prevented cattle from grazing locoweed. Prevention of locoweed poisoning at this point in time lies exclusively in not allowing animals to graze locoweed-infested areas when it is relatively more palatable than associated forages.

\section{Population Cycles Of Broom Snakeweed In The Colorado Plateau And Snake River Plains}

\section{M.H. Ralphs and K.D. Sanders}

Broom snakeweed is an aggressive native half shrub that increases following disturbance from grazing, fire and drought. The objective of this study was to monitor its populations in the Colorado Plateau and Snake River Plains and to relate its cycles to precipitation patterns. Snakeweed populations died out in drought and established and increased when winter and spring precipitation was abundant. Control options depend upon its stage in the population cycle. 


\section{Monitoring A Half-Century Of Change In A Hardwood Rangeland}

Kerry L. Heise and Adina M. Merenlender Elk And Cattle Forage Use Under
A Specialized Grazing System
Lacey E. Halstead, Larry D. Howery, George B. Ruyle, Paul R. Krausman, and RobertI. Steidl
Documenting changes in rangeland species composition is important in assessing forage quality, ecosystem function and biological diversity but difficult because accurate historic records are seldom available. We compared the modern flora of a 2,168 ha hardwood rangeland in Mendocino County, California to herbarium records of the site dating from the early 1950's. Species gains and losses, and changes in species abundance for both native and non-natives were documented. Livestock grazing, competition with invasive species, conversions to different vegetation types, and transportation of propagules into the site by vehicles and livestock are posed as the most likely causes for these changes.

\section{Large Ungulate Habitat Preference in Chobe National} Park, Botswana

\section{Uyapo J. Omphile and Jeff Powell}

Concentrations of large ungulate and wildlife tourists along the Chobe River, Botswana during the dry season may affect the wildlife habitat. A twice daily ground reconnaissance inventory was collected of 5 most common large ungulates along tourist routes in 5 habitat types every other month for a 2 -year period. Wildlife observations were highly correlated with nearness to the Chobe river, the major water source during the dry season. The Park management is faced with the decision of how best to optimize the biological needs of Park animals and their habitat with the economic and recreational desires of Park users.

\section{Density And Reproductive Success Of Florida} Grasshopper Sparrows Following Fire

Michael F. Delany, Stephen B. Linda, Bill Pranty, and Dustin W. Perkins

Intensive management of grasslands for cattle grazing and conversion of grassland to other agricultural use is considered the greatest threat to the endangered Florida grasshopper sparrow. Territory spot-mapping and estimates of reproductive success were examined in relation to time post-burn in managed cattle pastures at Avon Park Air Force Range, Highlands County, Florida from 1997-1999. Contrary to previous work, there was no evidence that Florida grasshopper sparrow territory density depended on years post-burn. Our results suggest increased reproductive success at a population level 0.5 year following fire, and did not suggest an association between territory density and individual reproductive success.
Specialized grazing systems that have been developed for cattle use may modify elk distribution. A 2-year study in Arizona evaluated a grazing system to test whether the system facilitated proper forage use and residual stubble height guidelines, and whether it rested one half of the allotment from elk and cattle grazing. The grazing system did not provide complete rest because elk used all pastures, but forage use and residual stubble height guidelines were met. Elk grazing patterns were apparently more dependent on tree cover and topography that any changes in forage quantity or quality caused by the grazing system.

\section{Fingerprint Composition Of Seedling Root Exudates Of Selected Grasses}

Johan F. Dormaar, Bonnie C. Tovell and Walter D. Willms

The competitiveness of plants within a community is influenced to some extent by their association with microorganisms in the soil. The chemical composition of root exudates, that might affect the interaction with the soil microorganisms, was identified from the seedlings of selected decreaser, increaser and invader grasses. Although the study did not identify why some plants are decreasers, while others are increasers or invaders, the suite of constituents identified were qualitatively, but not semi-quantitatively similar. The study was only designed to identify potential fingerprint compositions not their ecological effects.

\section{Long-Term Impacts Of Livestock Grazing On Chihuahuan Desert Rangelands}

Joseph M. Navarro, Dee Galt, Jerry Holechek, Jim McCormick and Francisco Molinsar

Long-term studies are needed that characterize changes in vegetation in different biomes in response to livestock grazing management. Rangeland ecological condition was monitored over a 48 year period on 41 sites in southwestern New Mexico using a modified Parker 3- step method. At the end of the 48-year study (1952-1999), the average rangeland ecological condition score across study sites was the same, as at the beginning of the study ( $39 \%$ versus $41 \%$ remaining climax vegetation, respectively). This research shows controlled livestock grazing is sustainable on Chihuahuan Desert rangelands receiving from $26-35 \mathrm{~cm}$ annual precipitation. 


\section{Effects Of Early Weaning And Length of Supplementation On Beef Calves}

\section{A. J. Pordomingo}

Two studies were conducted to evaluate performance of calves weaned at different ages and allowed to graze alfalfa pasture. Calves weaned at 70 to 80 days of age were the most affected by feeding programs with a supplementation period on pasture shorter than 45 days. Shortening of supplementation period on pasture to 15 days after weaning can have negative effects on performance but, the effect was less dramatic when calves were 90-days old or older at weaning time. If calves are younger, supplementation during at least 45 days may be necessary to achieve an acceptable growth rate.

\section{Calibrating Fecal NIRS Equations For Predicting Botanical Composition Of Diets}

John W. Walker, Scott D. McCoy, Karen L. Launchbaugh, Merrita J. Fraker, and Jeff Powell

Because material being predicted is not available for standard laboratory analysis, use of near infrared spectroscopy (NIRS) to predict dietary parameters of grazing animals presents unique challenges and limitations. Results of three feeding trials that were considered different populations showed predictions of percent sagebrush in the diet within the same population were precise and accurate. When calibrations were from a different population than the samples predicted, resultant predictions were not accurate but they were precise (high $\mathrm{R}^{2}$ ). NIRS predictions using fecal material represents an interval level of measurement, which contains sufficient information for addressing many questions on rangelands.

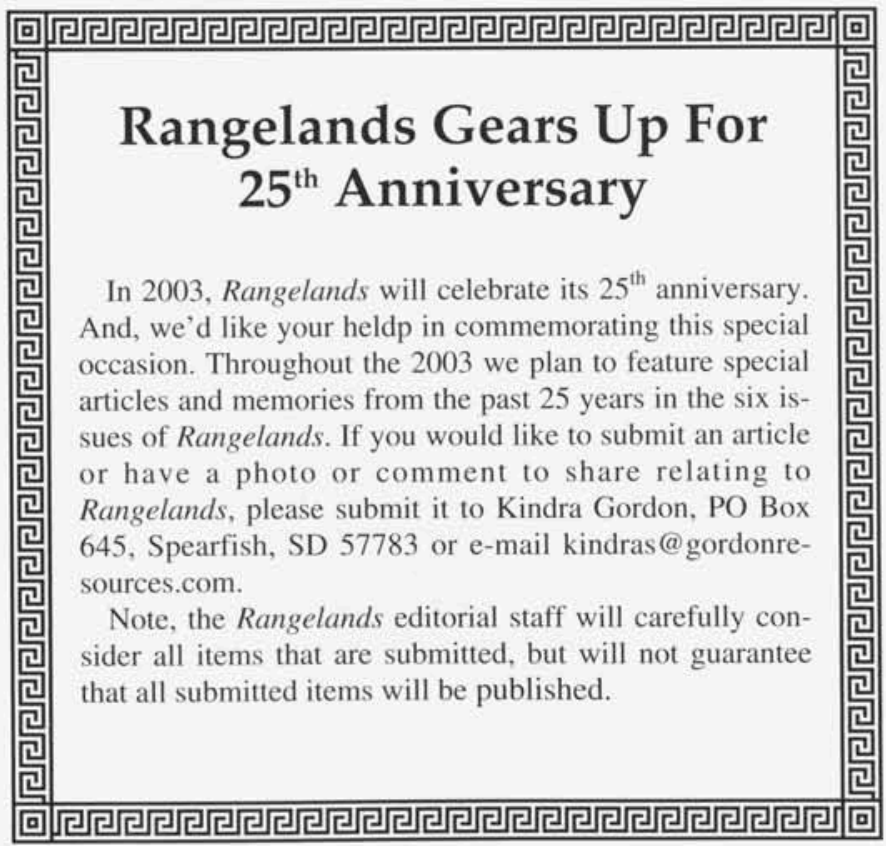

Clipping And Precipitation Influences On Locoweed Vigor, Mortality and Toxicity

Michael H. Ralphs, Dale R. Gardner, J.David Graham, Gary Greathouse, and Anthony P. Knight

White locoweed causes chronic poisoning in livestock. White locoweed plants were clipped annually in New Mexico, Colorado and Utah to determine the impact of this stress on subsequent vigor and mortality. Clipping did not substantially reduce vigor, increase mortality, or affect toxicity, however, most locoweed plants died during drought periods in the respective regions. Increasing grazing pressure to force consumption of locoweed will not likely reduce white locoweed populations.

\section{COLLEGE OF AGRICULTURE}

The Department of Animal and Range Sciences (ARSc) invites applications for the position of Department Chair. The department has 25 full-time faculty and 40 support personnel. Strong programs of research are conducted in several areas ranging from animal production systems to molecular biology. Centers of excellence include reproductive physiology, ruminant nutrition, range science and natural resource management. Departmental facilities include extensive animal units and an off-campus range research facility. ARSc faculty advise approximately 220 undergraduate students and 45 graduate students. Strong extension programs are conducted in range, beef, dairy, sheep, swine and animal products. The successful candidate will serve as administrative officer and program leader for the department and will provide leadership and participate in the ARSc research, teaching and extension programs. The Chair will represent the department to the university, professional associations and related groups, and will interact with Directors of the Ag Experiment Station, Extension Service and off-campus Research and Extension Centers. The successful candidate must have a doctorate in Animal or Range Sciences or a related field, demonstrate significant accomplishments in teaching and research, and be qualified for appointment to the rank of Professor with tenure in the department. Candidates must demonstrate leadership, communication and team-building skills and possess strong interpersonal abilities. Preference will be given to candidates with administrative experience in fiscal and personnel management, and with a commitment to the land grant mission. For further details see the departmental web site:

http://www.ag.ndsu.nodak.edu/ars/templates/indexes/programindex.htm. Review of applications begins September 1, 2002 and will continue until a suitable candidate is identified. Send 1) a statement of interest and evidence of qualifications for the position, 2) curriculum vitae, 3) a statement of the role of an Animal and Range Sciences Department in the college, state, and region, and 4) names, telephone numbers, postal and e-mail addresses of 5 references to: Dr. Douglas A. Freeman, Committee Chair, Department of Veterinary and Microbiological Sciences, 150 Van Es Hall, 1523 Centennial Blyd, North Dakota State University, Fargo, ND 58105, PH. 701-231-8504, FAX. 701231-7514, email: douglas.freeman@ndsu.nodak.edu.

NDSU is an equal opportunity institution. 


\title{
Listening To The Land
}

\section{How Am I Theirs/If They Cannot Hold Me/But I Hold Them*}

\author{
By Thad Box
}

Episcopalian Bishop Carolyn Tanner Irish told a group of writers and scientists that wonder is a seminal human experience that explores connection between the spiritual and physical worlds. It leads to curiosity about nature, such as the connection between light and growth of plants or the death of plants in unsuitable soil. In satisfying that curiosity, humans accept a responsibility for nature. And responsibility raises a moral sensibility that includes arbitrating justice for plants, animals, and people.

Bishop Irish said that both science and religion were asleep on their watch during most of the $20^{\text {th }}$ Century when land was overused, species became extinct, and "nature" suffered. I was one of the few range people present, but her words were appropriate for our profession. While we can be justifiably proud of improvement in specific areas of rangeland, we have been an ineffective voice, if not asleep, in conveying the moral responsibility for land to the average citizen.

This responsibility, or stewardship, for land was suggested in Mort Kothmann's viewpoint article (December Rangelands, pg.48) in which he suggested SRM change its name to Society for Land and Conservation Management. He wrote, "Land is a broad concept that includes the soils, topography, water, flora, fauna, and climate. The terms, and the concepts that they embody, are readily translated and understood in different languages and cultures."

Although I have not decided if I agree with Mort on name change, I heartily endorse the concept that we concentrate on land. Our history shows that land health was why we formed. It was food that fed our growth. It keeps us alive today. And I accept Bishop Irish's admonishment that we have a moral and spiritual tie to land.

While our forefathers acknowledged a Higher Power, they only saw his gifts in harvests, wrote Ron Daines in the February 2002 Western Farmer Stockman. He said Native Americans thanked a Great Spirit for land that gave them corn. White men gave thanks for the corn. This speaks directly to one of the problems facing SRM. I believe this separation of our sustenance from its source is at the root of our apparent declining effectiveness.

We celebrate uses (grazing, hunting, recreation) rather than land itself. We are not alone. The nature writers at the conference celebrated romance of the outdoors. Conservation biologists seek ecological services. All tend to crave things rather than laud the giver of those things.

We value land by things we take from it. An appraiser determines value by its highest economic use. Aldo Leopold wrote "It is inconceivable to me that an ethical relationship to land can exist without love, respect, and admiration for land, and a high regard for its value. By value, I of course mean something far broader than mere economic value." Those who love the land know its worth is related to the wholeness of humankind.

Good farmers know a greater power in land than growing wheat from it. Husbanding the soil, they become part of it. Good ranchers know that producing fat calves will not make up for an eroding stream bank. Mother Earth births both trout and lambs. Wilderness advocates know the human spirit soars in beauty of landscapes. All who love land share common values. Those who live for "things" and ignore the land's health are acting like a spoiled child.

Terry Tempest Williams said her book "Red," was written to prevent the erotic [land experience] from becoming pornography. Yet some land use is pornography at its most basic; it has no redeeming social value. Look at overgrazed pastures, hills scarred by ATVs so someone can get his high. Look at trash and garbage that clogs streams and blankets campgrounds where people take their pleasure and walk away.

Williams suggests that land debates become complicated very quickly as abstractions turn into specific uses, whether it's cows grazing on public lands or the designation of wilderness. My experience is that in the politics of defending "our use," we act like teenage gangs-Crips and Bloods protecting turf while community rots.

Pornography exists when we promote "use" rather than land health. We participate in porn if we defend livestock grazing, or any other industry, that diminishes sustainability. Our concept of pornography may differ over whether a woman's breast is covered by burka, modest dress, sports bra, bikini, pasty, or nothing at all. Real pornography exists when women lose their breasts and die from cancer-causing toxins because of the way we use land.

We should never shy away from discussing uses of rangeland. I disagree with, but staunchly defend, Bob Ross's right to opine that endangered species will cause ranchers to be replaced by prairie dogs and suckers. Kothmann's suggestion in the April Rangelands that SRM membership is not unified on our "cows and grass" image should lead to healthy debate. As should Howdy Howard's question, "Does nature want us to kill wild animals?"

But let our debate be about land health, not use. Land does not belong to us; we belong to the land. Listen to the earth-song in Ralph Waldo Emerson's poem "Hamatreya:" "They called me theirs/Who so controlled me:/Yet every one/Wished to stay, and is gone,/How am I theirs,/if they cannot hold me,/but I hold them."

Some say SRM is fast becoming irrelevant. Or it needs a new name. We must examine these issues. Whatever our name, we have a needed purpose: to act on the moral sensibility Bishop Irish says leads to an ethical responsibility. This responsibility was beautifully stated by Aldo Leopold, "A land ethic, then, reflects the existence of an ecological conscience, and that in turn reflects a conviction of individual responsibility for the health of the land."

Leopold gives us, as a profession, our marching orders, "The mechanism of operation is the same for any ethic: social approbation for right actions; social disapproval for wrong actions." When we in SRM use our science, our intellect, our collective strength to accept Bishop Irish's call for responsibility and justice by applying fully the land ethic, we can claim to be a profession. And no one can doubt our reason to exist.

* from the earth-song in Ralph Waldo Emerson's poem Hamatreya 


\title{
Browsing The Literature
}

\author{
Jeff Mosley
}

\begin{abstract}
This section reviews new publications available about the art and science of rangeland management. Personal copies of these publications can be obtained by contacting the respective publisher or senior author (addresses shown in parentheses). Suggestions are welcomed and encouraged for items to include in the future issues of Rangelands.
\end{abstract}

Animal Ecology

Avian responses to late-season grazing in a shrub-willow floodplain. T.R. Stanley and F.L. Knopf. 2002. Conservation Biology 16:225-231. (U.S. Geological Survey, Midcontinent Ecological Science Center, Fort Collins, CO 80525). Results suggest that habitat restoration for grazing-sensitive birds can occur with late-season cattle grazing.

Conditioning taste aversions to locoweed (Oxytropis sericea) in horses. J.A. Pfister, B.L. Stegelmeier, C.D. Cheney, M.H. Ralphs, and D.R. Gardner. 2002. Journal of Animal Science 80:79-83. (USDA-ARS, Poisonous Plant Research Lab, 1150 E. 1400 North, Logan, UT 84341). Grazing horses were successfully averted from locoweed using lithium chloride.

Dried poultry waste for cows grazing low-quality winter forage. D.J. Jordon, T.J. Klopfenstein, and D.C. Adams. 2002. Journal of Animal Science 80:818-824. (T. Klopfenstein, Dept. of Animal Sci., Univ. of Nebraska, Lincoln, NE 68583). While grazing native Sandhills rangeland in winter, cows fed a supplement containing dried poultry waste performed as well as cows fed a soybean meal supplement.

Effects of supplementation on intake, digestion, and performance of beef cattle consuming fertilized, stockpiled bermudagrass forage. J.S. Wheeler, D.L. Lalman, G.W. Horn, L.A. Redmon, and C.A. Lents. 2002. Journal of Animal Science 80:780-789. (D. Lalman, 201 Animal Sci. Bldg., Oklahoma State Univ., Stillwater, OK 74078). Supplemental protein increased utilization of stockpiled bermudagrass pastures in late winter.

\section{Grazing Management}

Dry matter, crude protein and cell wall digestion of total plant, leaves and stems in Llano buffelgrass (Cenchrus ciliaris). R. Foroughbackch, R.G. Ramirez, L.A. Hauad, J. Alba-Avila, C.G. Garcia-Castillo, and R. Morales-Rodriguez. 2001. Journal of Applied Animal Research 20:181-188. (Univ. Autonoma Nuevo Leon, Ciencias Biol., Apartado Postal 142, Sucursal F, San Nicolas De Los Garza 66450, Mexico). Concluded that Llano buffelgrass pasture is best used in summer.
Impacts of grazing systems on soil compaction and pasture production in Alberta. N.T. Donkor, J.V. Gedir, R.J. Hudson, E.W. Bork, D.S. Chanasyk, and M.A. Naeth. 2002. Canadian Journal of Soil Science 82:1-8. (R. Hudson, Dept. of Renewable Resources, Univ. of Alberta, Edmonton, AB T6G $2 \mathrm{H} 1$, Canada). High intensity-short duration grazing did not enhance soil physical characteristics and herbage production in an aspen boreal ecosystem when compared with moderate intensity-continuous grazing.

\section{Hydrology/Riparian}

Avian and amphibian use of fenced and unfenced stock ponds in northeastern Oregon forests. E.L. Bull, J.W. Deal, and J.E. Hohmann. 2001. USDA Forest Service Pacific Northwest Research Station Research Paper 539. (Publications Dept., Pacific Northwest Research Station, P.O. Box 3890, Portland, OR 97208). Fenced stock ponds had a greater diversity and abundance of birds, but fenced and unfenced ponds did not differ in their abundance of Pacific tree frogs or long-toed salamanders.

Effects of Phalaris arundinacea and nitrate-N addition on the establishment of wetland plant communities. E.K. Green and S.M. Galatowitsch. 2002. Journal of Applied Ecology 39:134-144. (Dept. of Horticultural Sci., Univ. of Minnesota, 1970 Folwell Ave., St Paul, MN 55108). Reed canary grass out-competed native sedges and grasses in meadows adjacent to prairie wetlands.

\section{Improvements}

Biological control of leafy spurge: Informational resource CD. Team Leafy Spurge. 2002. (USDA-ARS, Northern Plains Agr. Research Lab, 1500 North Central Ave., Sidney, MT 59270). A comprehensive review of how to obtain and use biological control agents to control leafy spurge.

Burning and grazing management in a California grassland: Effect on bunchgrass seed viability. A.R. Dyer. 2002. Restoration Ecology 10:107-111. (Dept. of Biology and Geology, Univ. of South Carolina, Aiken, SC 29801). Purple needlegrass seeds from burned plants had higher germination than seeds from unburned plants, and seeds from plants that were both burned and grazed had the highest germination.

Controlling invasive Arrhenatherum elatius and promoting native prairie grasses through mowing. M.V. Wilson and D.L. Clark. 2001. Applied Vegetation Science 4:129-138. (Dept. of Botany and Plant Pathology, Oregon State Univ., Corvallis, OR 97331). Four years of mowing at $15 \mathrm{~cm}$ in late spring converted a tall oatgrass site to a prairie dominated by native grasses. 
Fire effects on resprouting of shrubs in headwaters of southeastern longleaf pine savannas. P.B. Drewa, W.J. Platt, and E.B. Moser. 2002. Ecology 83:755-767. (USDAARS, Jornada Exp. Range, MSC 3JER, Box 30003, New Mexico State Univ., Las Cruces, NM 88003). Reintroducing growing-season prescribed fires that resembled the natural fire regime neither increased nor decreased densities of established shrubs.

Purge spurge: Leafy spurge database, version 4.0. Team Leafy Spurge. 2001. (USDA-ARS, Northern Plains Agr. Research Lab, 1500 North Central Ave., Sidney, MT 59270). Latest version of $\mathrm{CD}$ that now contains more than 900 documents, all focusing on the biology and management of leafy spurge.

Restoring grassland savannas from degraded pinyon-juniper woodlands: Effects of mechanical overstory reduction and slash treatment alternatives. D.G. Brockway, R.G. Gatewood, and R.B. Paris. 2002. Journal of Environmental Management 64:179-197. (USDA Forest Service, 520 Devall Dr., Auburn, AL 36849). "Even though all slash treatment alternatives increased the cover and biomass of native grasses, scattering slash across the site to serve as a mulch appears most beneficial to improving plant species diversity and conserving site resources."

Using imazapic and prescribed fire to enhance native warm-season grasslands in Kentucky, USA. B.E. Washburn, T.G. Barnes, C.C. Rhoades, and R. Remington. 2002. Natural Areas Journal 22:20-27. (Dept. of Fisheries and Wildlife Sci., Univ. of Missouri, Columbia, MO 65211). Native warm-season grasses increased after tall fescue was effectively controlled with one application of imazapic herbicide.

\section{Management Planning}

Adaptive management in habitat conservation plans. G.F. Wilhere. 2002. Conservation Biology 16:20-29. (Washington Dept. of Fish and Wildlife, 600 Capitol Way North, Olympia, WA 98501). Suggests that economic incentives be created to encourage adaptive management of threatened and endangered species, and suggests that land users be required to post an environmental assurance bond that is gradually returned as adaptive management demonstrates that environmental damages are unlikely to occur.

Conserving endangered and threatened species on private land. B.J. MacGowan. 2001. Purdue Univ. Cooperative Extension Service Bulletin FNR-172. (\$1; Purdue Cooperative Extension Service, Ag Communications, Media Distribution Center, 1187 Service Bldg., West Lafayette, IN 47907-1187). This bulletin explains how Safe Harbor Agreements and Habitat Conservation Plans can assist private landowners when federally listed species inhabit their private lands.

\section{Plant-Animal Interactions}

Ant communities and livestock grazing in the Great Basin, USA. M.S. Nash, W.G. Whitford, D.F. Bradford, S.E. Franson, A.C. Neale, and D.T. Heggem. 2001. Journal of Arid
Environments 49:695-710. (Environmental Protection Agency, P.O. Box 93478, Las Vegas, NV 89193). Ant communities did not differ between sites in good or fair ecological condition, but ant abundance and ant community composition were different on poor condition sites.

Consumer control of grassland plant production. D.A. Frank, M.M. Kuns, and D.R. Guido. 2002. Ecology 83:602606. (Biological Research Lab, Syracuse Univ., Syracuse, NY 13244). Ungulate grazing stimulated aboveground, belowground, and whole-grassland productivity in Yellowstone National Park.

Research highlights-2001. P.J. Zwank and L.M. Smith. 2001. Volume 32. (Dept. of Range, Wildlife, and Fisheries Management, Texas Tech Univ., Lubbock, TX 79409). Progress report describing 52 research projects in the Department of Range, Wildlife, and Fisheries Management at Texas Tech University.

\section{Plant Ecology}

Nitrate toxicity in Montana forages. D. Cash, R. Funston, M. King, and D. Wichman. 2002. (\$1; MSU Extension Publications, Culbertson Hall, Montana State Univ., Bozeman, MT 59717). This bulletin presents management strategies to avoid nitrate poisoning of livestock from annual forage crops.

\section{Reclamation/Restoration}

Restoring riparian meadows currently dominated by Artemisia using alternative state concepts-the establishment component. J.C. Chambers and A.R. Linnerooth. 2001. Applied Vegetation Science 4:157-166. (USDA Forest Service, 920 Valley Rd., Reno, NV 89512). Prescribed burning and reseeding can restore dry meadow sites dominated by basin big sagebrush.

Seedling survival from locally and commercially obtained seeds on two semiarid sites. L.D. Humphrey and E.W. Schupp. 2002. Restoration Ecology 10:88-95. (1437 Hillcrest Dr., Buford, GA 30518). Survival to the third year did not differ between seedlings from locally obtained seeds and commercially obtained seeds. Seven native species were evaluated.

\section{Socioeconomics}

Social values in the assessment of livestock grazing in the Great Plains. R.K. Heitschmidt, J.D. Johnson, and K.D. Klement. 2001. Great Plains Research 11:361-374. (USDAARS, Fort Keogh Livestock and Range Research Lab, RR 1, Box 2021, Miles City, MT 59301). Discusses reasons why properly managed livestock grazing is ecologically sustainable, but not always economically sustainable or socially acceptable.

Author is professor of range science and Extension range management specialist, Dept. of Animal and Range Sciences, Montana State Univ., Bozeman, Mont. 59717. 


\section{Letters to the Editor}

\section{Dear SRM:}

I thought I would just let you know that I have virtually retired and therefore feel little need to keep up with the scientific literature and had resolved to give up my professional journals. However your letter reminded me that rangelands around the world have meant much to me, a fulfilling (if poorly paid!!) career, many wonderful environments visited and friends made. I therefore changed my mind and renew my membership to assist the stewardship of the mountains, desert and prairies of your wonderful West, the mountains of the UK and the wildnernesses of Africa and India which have also inspired me. I regret never having attended a SRM meeting but perhaps I will now have time. Please don't bother to acknowledge this letter. I just thought you should know that expressing the sentiments in your letter have some effect.

Yours Sincerely,

Cedric Milner

United Kingdom

\section{Dear Editor:}

I understand that when an author submits a book for review that the reviewer's comments may not be positive. I am use to that, as my book does not present what is generally accepted as "fact" regarding Los Angeles, Owens Valley, and water issues. However, in this instance $I$ feel it is imperative to respond to David Scarnecchia's negative review of my book "The Owens Valley Controversy and A.A. Brierly: The Untold Story." I am a bit dismayed by David's personal attack on me. I can understand his frustration with finding new information that contradicts his obvious bias on the issues of Los Angeles and the Owens Valley, but I would have at least thought he would have had the consideration to keep the review professional as opposed to personal.

Additionally, the review has several significant errors. For example he states "the author's 16-page account of the water controversy" the chapter he is revering to is nothing of the sort. It is not my account, but a summary of an interview with my Grandfather and Gus Cashbaugh, both residents of Owens Valley during the period Los Angeles was buying land in Owens Valley (the first sentence of the chapter says "I have been given this information by my eighty-nine year old grandfather...").

Also he states one chapter is "a 30-page transcript of an interview Dr. Pearce conducted with his grandfather 25 years ago" which is also inaccurate. Instead, the chapter contains a transcript of an interview by Cal State Fullerton's Oral History Program (again, the first line of the chapter states "The following is a transcript of an interview conducted by Charles Ellis Delameter...").

I would further like to point out a few of David's misconceptions. My book is not a scholarly attempt to give in detail all aspects of the issues. In my book I suggest readers who want a thorough examination of the topic read books like Vision or Villainy (Hoffman 1981), or scholarly works like Los Angeles and the Owens River Aqueduct (Miller 1978, dissertation), among others.
My book is intended to be a personal view based on first hand accounts, and it is intended to be from the heart. My book is a presentation, as clearly stated, of my grandfather's involvement in Owens Valley and how he influenced my thinking and is intended to give another point view on the Los Angeles/Owens Valley issue. I may be full of "syrup" as David says, but I am proud of my family and our history in the Valley.

Further, I am accused of having an "absence of significant research." My book has reference to four of the most significant and authoritative publications on the Owens Valley issues, which is more than enough for the type of book it is. It also has accounts from the local paper of that period, personal diaries, and data from EPA related to dust in the Valley. Not to mention that I have read everything I could get my hands on related to the Los Angeles and the water issue. I have also spent multiple days at UC Berkeley in their Water Resources Library, an extensive California water issue archive, collecting information about the water issues in Owens Valley. Nothing I have ever read contradicts what my grandfather told me.

I understand David prefers to believe the Hollywood movie fantasy "Chinatown" as fact, compared to what people who lived during the time had to say, but that is his choice. I would prefer to believe people who lived their lives in Owens Valley, and were politically active in the water issues from the 1900's through 1970s as opposed to a silly quote by Jack Nicholson. Additionally, he says my grandfather was over 90 when he told me the story, insinuating that maybe his age might have clouded his memory. Did it ever occur to David that what my grandfather told me when he was 90 , or when he was 98 for that matter, and what he wrote as a younger man, and his multiple interviews with academics from all regions of the country, was always the same. My grandfather was an avid historian who was sought out for many years by academics interested in Owens Valley. David might not know of him, but many scholars did, and readily sought his insight, information, and recollections.

There have been 5 generations of my family in Owens Valley, all of us have been involved with the politics of the region and contribute positively to the area. Those of us still living in Owens Valley are involved with issues regarding water and politics. I don't need to be told it is serious business. I know the events and politics first hand, not through movies.

Abraham Hoffman, author of Vision or Villainy, and scholar on Owens Valley Water issue, had the following to say about the movie Chinatown, which David appears to believe as fact, "As if seeing the movie made them instant experts on the history. "Chinatown," of course, created its own myths and distortions. While it successfully recreated an era of political intrigue and mystery, it obscured basic facts by setting the story in the $1930 \mathrm{~s}$ instead of the early 1900 s, murdering the Mulholland character, and even injecting incest into the plot. I have found that in talking to anyone whose interest in the water controversy was whetted by seeing "Chinatown," I first have to strip away all of the fictional devices in the film in order to start discussing the history." Further, Hoffman said in a review of my book "Anyone who gets "historical" information from movies such as Chinatown or popularizations such as Marc Reisner's Cadillac Desert or journalists 
with an axe to grind falls into the trap set by knowing a lot about a little knowledge." and "Owens Valley residents whose minds are made up and don't want to be confused with alternative views of their "history" would not like Pearce's book, but more openminded people would find its message worth pondering. It's a small book that may be read in an evening, but it has a big message that comes from someone whose family credentials in Owens Valley cannot be denied."

Finally, David's last dig at me, is insulting and insensitive "Forty years from now Dr. Pearce may be standing on that same hilltop, this time with his eyes wide open, with his grandson asking him what he did to tell the family history, to tell what a great guy his grandfather was and to save the valley from destruction by greedy people." First off, I likely will not be on this planet in forty years; second, there are no more generations of my family. My generation is the last of us. I won't ever stand on a hill with a grandchild, but if I did, I would tell him his great-great grandfather was an outstanding individual who dedicated his life to Inyo County; working 65 years (from 1905 to 1970) without pension or benefits. I would say he lived an honest life, had integrity and character, and didn't tear others down to make himself look better or to substantiate his own views. I would say his great-great grandfather was part of the era when events that shaped the Owens Valley occurred, that he was a participant in turbulent times and he had a clear vision of what happened, and that he passed that information to me. Then I would say his great grandparents lived their lives in Owens Valley and contributed to the community and knew of the water issues and were involved with them too. I would tell him I worked in the Valley most of my life and help the resources, as a consultant, rancher, and land manager. I would suspect I would have said the same of his parents, had they ever existed. I would show him of the book I wrote to pay tribute to our family, and to honor his great-great grandfather. I would say it took 5 years to complete, that it was reviewed by many, professional editors included. I would say it was controversial, but it added information and another point of few to an often one-sided argument. I would say it was an honest book about a family's roots, and how one man felt about issues that deeply impacted his life, and that is all it was suppose to be.

\section{Rob Pearce}

\section{Dear Editor}

I refer to the article "The Statistical Power of Rangeland Monitoring" in the April 2002 issue of Rangelands.The opening paragraph is totally not true, is unprofessional and thus misleading. The paragraph does not say "some" federal leases by "some" federal agencies. Neither the FS or BLM are aware of such a court mandated monitoring requirement nor are the they "scrambling" to comply.

It is also not true that "little attention has been paid to the methods of monitoring". BLM and FS have been conducting monitoring for many years using research based methods, which I am certain you are aware of.

SRM is a professional organization and should be checking the validity of the articles they publish. 1 have been a member now for nearly 45 years.

This is another, in a series of article, where the so called "Certified Range Consultants" are trying hard to make the case that only they are capable of conducting monitoring and only they understand the data collected from public land and that the federal range managers are not capable to do the monitoring or interpret it.

\section{George Lea (retired BLMer)}

\section{Dear Editor}

Here is an item that I would like to submit as a "Viewpoint". "What is the Real Reason SRM Membership has Declined?"

Over the course of the past year much as been written in Rangelands and the Trail Boss News about the decline in SRM membership and what can be done about it. Implicit, in most of these articles, is idea that the decline in membership is due to the SRM not keeping up with the times, and hence a major overhaul of the Society's focus and image is in order.

Certainly, a little soul searching never hurt any organization. But before we overhaul the SRM, let us make sure that the problem really is with the focus and image of the organization. To understand the declining membership we must first determine the SRM's traditional membership base and how the political-economic changes of the past 25 years have affected them. The SRM has always had members who are university faculty and a few ranchers as well. Yet, the bulk of the membership base has been federal agency Range Conservationists and experiment station personnel.

The political mindset in the United States for the past 25 years has been that everybody wants to cut taxes, yet nobody wants to cut entitlement programs, be they Social Security and Medicare or farm subsidies. As a result, what ends up being cut from the federal and state budgets is "infrastructure", which includes natural resource conservation and scientific research.

In 1991 I heard Duane Rice of the NRCS speak at a Kansas SRM function. He told how when he started his career in the early 1980's, the then Soil Conservation Service had over 20 Range Conservationists in Kansas. By 1999, its heir, the NRCS, had four Range Conservationists on its payroll in the state. The same is true with other federal agencies. Ten years ago, a Forest Service Range Conservationist in Wyoming lamented to me that he was unable to find the budget to hire seasonal help. At the time his district was involved in a sticky elk-cattle conflict as well as concerns over the overuse of riparian areas. He remarked "One of these days we are going to get sued, be it by the grazing permit holders, the state wildlife department or an environmental group. And when that happens, we are going to lose because we don't have the human resources to document the range conditions and trends which are the rationale behind our management decisions."

Experiment stations have not fared much better. Three years ago we had a County Extension Agent in Ness County, KS with a Ph.D. in Rangeland Ecology. I asked him what a person with a Ph.D. in Rangeland Ecology was doing working as a County Extension Agent. He told how he was the superintendent of a small research center that ended up getting closed. Before he landed the County Agent job he was working stocking shelves in a discount store in Colorado. The story has a happy ending as this gentlemen was eventually able to secure a position as a Range Management Specialist for the University of Wyoming Extension Service. Still, when we have people with Ph.D.'s in Rangeland 
Ecology stocking shelves in discount stores and a state NRCS office reducing its staff of Range Conservationists $80 \%$ in less than 20 years, one shouldn't have to wonder wy SRM membership is declining. As the well-being of SRM members goes, so goes the well-being of SRM. Before the SRM can bring people back into the organization, it first has to bring them back into the profession.

The SRM's principal failure has been that it has been so busy promoting the concepts of Range Management that it neglected to take decisive political action to guard the livelihoods of Range Management professionals. No organization wants to be seen as a pushy mob trying to wring every possible dollar from the federal and state treasuries. Yet, the SRM needs to be out front making the case that cutting infrastructure in order to cut taxes and protect entitlements is short-sighted.

Not only has the SRM failed to secure more funding for research and conservation, it has failed to protect its turf in private industry. In $1996 \mathrm{I}$ was working as a Cattle Health Technician at a feedyard in Central Kansas which purchased a ranch in the Kansas Flint Hills. At the time I had a MS in Range Science and considerable cow-calf experience. There was also a former penrider from the feedyard who was a graduate of Texas Christian University's excellent Range Management program. At the time he was working as a cowboy on a ranch not far from the ranch that the feedyard purchased. You would have thought that either one of us would have been a logical choice to manage the ranch. Yet they hired a former yard foreman from the feedyard, a person with considerable cattle experience but only limited Range Management knowledge.

The idea of SRM promoting legislation that requires absenteeowned ranches to hire Range Management graduates as managers may come across as being un-American. But consider the absurd lengths that other professionals such as Veterinarians have gone to in order to protect their turf. In Kansas it is illegal for anyone other than a licensed veterinarian to pregnancy test cattle for a fee. There are cases where purebred operations hire ultrasound technicians to scan their heifers for carcass traits, and even though the ultrasound technicians can clearly see a pregnancy on their screen, they cannot legally "diagnose" the pregnancy and hence the operation has to hire a veterinarian to diagnose the pregnancy. The laws in Kansas against practicing Veterinary Medicine without a license are so broad that a cowboy who hires out his services to ride pastures and treat sick cattle is technically in violation of the law. If someone is trained in Range Management with no formal training in Veterinary Medicine is not allowed to practice Veterinary Medicine, why should a Veterinarian with no formal training in Range Management be allowed to manage a ranch?

The SRM doesn't need to change its image or its focus, it needs to change its politics. I am about as pro-livestock grazing as a person can be. Yet what has the NCBA (National Cattlemen's Beef Association) done for the SRM after all of the times that the SRM has come to their aid when livestock grazing on public lands was threatened? It is time that the SRM asked for some favors in return.

Finally, we come to the issue of the SRM broadening its membership base. In recent years the SRM has spread out the red carpet for Hydrologists, Ecologists, Plant Physiologists and Wildlife Biologists. I have no quarrel with this as these people have contributed much to the knowledge base of the profession. Yet it seems to me that there are others who have much to contribute, both intellectually and financially, which are not being courted. Specifically, Animal Scientists and Agronomists in the Eastern United States who are actively involved in grazing research with tame pastures. Much of their research has bearing on the management of native rangelands.

This spring at the SRM meetings in Kansas City, a bunch of us got together to discuss using polyethylene glycol to increase cattle consumption of sericea lespedeza, a high-tannin forage legume which has turned into an invasive weed on the Tallgrass Prairie. I invited an Animal Science professor from the University of Missouri who has researched high-tannin forage legumes to attend. He thanked me for the invitation, but explained that he had prior commitments. He then added "I didn't know that the SRM was meeting in Kansas city." The fact that this grazing researcher didn't know that the SRM was meeting 100 miles away from his campus, speaks volumes about how litthe the SRM has tried to reach people like him. I may sound paranoid, but I suspect that the failure of the SRM to reach out to people like this Animal Science professor is deliberate. People like him, and myself, represent the image that the SRM is trying to run from. The SRM has been very exclusive in its "inclusiveness". Many of those advocating a "broadening" of the SRM, in fact, want little more than to drive the cowboy hats out of the organization, and disassociate the SRM from anything that has to do with livestock grazing.

These days we live in the ear of image doctors and media consultants who seed to assure beleaguered organizations like the SRM that success is just one image change away. The SRM can continue wasting time in self-doubt about its image, focus, and "relevance". Or, it can roll up its sleeves got about the hard, dirty work of rebuilding the profession and in the process rebuilding its membership base. It is hard to build a growing professional organization in a shrinking profession. Until the SRM succeeds in rebuilding the Range Management profession, no amount of image doctoring and soul-searching will save the organization.

\section{Greg Mantz}

Bazine, Kansas 


\section{SRM Life And Life Sustaining Members 2002}

Kenneth G. Adams

Raymondo Aguirre

Eduardo Aizpuru-Garcia

Jack D. Albright

Ricardo V. Aldape

Bob Alexander

Jack D. Alexander III

Christopher Allison

Jonathon Anderson

Lora Anderson

Dean M. Anderson

E. William Anderson

Val Jo Anderson

Paul C. Anderson

Art J. Armbrust, Jr.

R. Lee Arthur

Neal E. Artz

Abdulaziz M. Assaeed

Josiah T. Austin

Calvin Baker

Nancy C. Ballard

Robert F Barnes

Patricia D. Barney

Eduardo J. Barragan

Reginald H. Barrett

Mack R. Barrington

Sheila J. Barry

Keith M. Bartholomay

John H. Baumberger

Rodney D. Baumberger

Jerry R. Bean

David J. Beard

Thomas E. Bedell

Alan A. Beetle

Robert E. Bement

R. Gordon Bentley, Jr.

William A. Berg

Rhonda L. Beyke

Craig Bienz

C. Robert Binger

Charles Birkemeyer

Kenneth R. Blan

D. Morris Blaylock

Vosila L. Bohrer

Eric G. Bolen

D. Terrence Booth

Michael Borman

Margaret Bowman

George E. Bradley

Vernon C. Brink

Patrick J. Broyles

H. Harold Bryant

Steve Bunting

A. Lynn Burton

Frank E. Busby, Jr.
Evert K. Byington

Dwight R. Cable

Margie M. Campbell

Bartley P. Cardon

Roy M. Carlson, Jr.

Jose F. Casco

Martha Chaney

W. James Clawson

C. Rex Cleary

Charles Clement

Alvin Buck Clements

Roy M. Clinesmith

Chet C. Clinesmith

James S. Cochrane

Elizabeth H. Colbert

Thomas A. Colbert

C. Wayne Cook

Richard L. Coose

Roy Copithorne

Max A. Corning

James A. Cornwell

Debra Sue Couche

Patrick I. Coyne

Nick J. Cozakos

Kent A. Crofts

William E. Cross

Arletta Cross

John L. Cross

L. Dean Culwell

Jack R. Cutshall

Jack Dahl

Nickole Dahl

Lawrence A. Daley

Robert A. Darrow

Gary G. Davis

Maurice R. Davis

Howard R. De Lano

Joe Deschamp

Wright Dickinson

Claude C. Dillon

Everett R. Doman

Gary B. Donart

Jim W. Doughty

Donald S. Douglas

John T. Drake

Richard E. Dresser

Robert S. Drinkwater

W. James Duffield

R. A. Dyer

E.J. Marge Dyksterhuis

Thomas K. Eaman

Douglas J. Eddy

Gerhard A. Ehlert

Virginia M. Emly

David M. Engle
Robert E. Epp

John Estill

Lani Estill

Angela G. Evenden

Mahlon Everhart, Jr.

Marion E. Everhart

Sherman Ewing

Dahir Abby Farah

Richard W. Farrar

Nancy R. Feakes

Karen Fechko

John E. Fend

Fredrick W. Finke

David A. Fischbach

Bruce Fischer

Joseph Fitzsimons, Jr.

George E. Fore

John S. Forsman

Richard T. Forsman

William A. Fortune

Bruce T. Foster

Philip H. Fox

Steven C. Fransen

Joeseph G. Fraser

Gary W. Frasier

Jo Frasier

Ed L. Fredrickson

Jim C. Free

Daniel G. Freed

John D. Freeman

Howard R. Freemyer

Leroy Friebel, Jr.

Dennis K. Froeming

Kenneth O. Fulgham

Trinida B. Garcia

Allen N. Garr

F. Robert Gartner

David A. George

Melvin R. George

Will R. Getz

Albrecht Glatzle, Sr.

Steven W. Glenn

Carl J. Goebel

Martin H. Gonzalez

Riche Gonzalez

David W. Goodall

Charles A. Graham

Irene E. Graves

Win Green

Thomas R. Grette

E. Lee Griner

David P. Groeneveld

John J. Gunderson

Margaret S. Gunderson

Robert H. Haas
Marshall R. Haferkamp

L. I. Hagener

Richard D. Hall

Robert Hamner

Eugene J. Handl

Edward B. Handley

Richard M. Hansen

Julie A. Hansmire

Bruce D. Hanson

Jackie L. Hanson

Earl E. Hardie

Glenn W. Harris

Robert W. Harris

Richard H. Hart

William J. Harvey

Doc \& Connie Hatfield

Craig M. Haynes

Harold F. Heady

Darwin C. Hedges

Dennis Heffner

Rodney K. Heitschmidt

Humberto Hernandez

O. N. Hicks

Joseph G. Hiller

Lynnel A. Hoffman

Charles A. Holcomb

Lee J. Holden

John R. Hook

Robert R. Humphrey

John R. Hunter

Richard M. Hurd

William D. Hurst

Donald L. Huss

W. O. Hussa

Margaret F. Hyatt

S. Wesley Hyatt

Milton Hyatt

Peter V. Jackson, III

Charles M. Jarecki

J. Rukin Jelks, Jr.

Dennis R. Jenkins

Thomas N. Johnsen, Jr.

Lyndon L. Johnson

James R. Johnson

Mark K. Johnson

Richard C. Johnson

Thane J. Johnson

William K. Johnson

Leonard W. Jolley

Robert C. Joslin

Bob L. Karr

Marvin R. Kaschke

Steven H. Kautzsch

David B. Kelley

James W. Kellogg 
Chester H. Kelly

Norman R. Kempf

Wayne Kessler

Robert R. Kindschy

Richard J. King

Austin E. Klahn

Leslie J. Klebesadel

Roger G. Knapp

Matt Kniesel, Jr.

Robert W. Knight

Ruthann Knudson

Paul A. Krause

Dirk A. Kreulen

Ron E. Lambeth

Robert A. Langford

Colleen G. Larkoski

Gary E. Larson

William A. Laycock

Henri N. Le Houerou

Robert D. LeBlanc

Charles L. Leinweber

Ernest Leland

Robert J. Leonard

Lawrence P. Lilley

W. Eric Limbach

James A. Linebaugh

Nelda D. Linger

Lawrence A. Long, Jr.

Richard V. Loper

H. H. Lundin

Walter J. Lusigi

Robert F. Lute, II

James R. Luton

John H. Lyman

John B. MacLeod

Norman H. MacLeod

Eugene I. Majerowicz

I. D. Maldonado

James I. Mallory

Raymond D. Mapston

Niels Leroy Martin

S. Clark Martin

Chris Maser

Henry F. Mayland

Harold E. Mayland

Richard D. McClure

V. P. McConnell

Kirk C. McDaniel

Neil K. McDougald

Dan McKinnon

John L. McLain

Eleanor McLaughlin

Floyd A. McMullen, Jr.

Patrick C. McNulty

Joel T. Meador

Daniel L. Merkel

John Merrill

Virginia Merrill
John L. Merrill, Jr.

Donald W. Messer

Keith H. Mickelson

Jason M. Mietchen

Wayne H. Miles

Jack R. Miller

Janice Miller

R. Keith Miller

Steven B. Miller

Willie Milliron

Randy V. Mills

Sara Lou Mills

John E. Mitchell

Billie Mitchell

Robert B. Mitchell

M. Pat Morrison

John R. Morse

Allen D. Morton

Mark E. Moseley

John W. Mumma

Don J. Neff

Stephen A. Nelle

Donald W. Nelson, Jr.

Joe B. Norris

Kay V. Norris

Edward L. Nygard

Paul E. Nyren

T. Michael O'Connor

Joseph F. O'Rourke

Paul D. Ohlenbusch

Hamdy S. Oushy

Kyle Owen

C. E. Owensby

Bob D. Patton

Gene F. Payne

Jerry L. Payne

Henry A. Pearson

Dorothy Pearson

Rudy J. Pederson

Mike L. Pellant

W. C. Pendray

Gregory K. Perrier

Ronald R. Perrin

Willard P. Phillips

Ellen J. Picard

T. Boone Pickens, Jr.

Beatrice C. Pickens

William D. Pitman

Rod Player

Jennifer J. Pluhar

Jeff Powell

J. Boyd Price

Jeffrey L. Printz

Charles M. Quimby

Clayton L. Quinnild

Klaus Radkte

Bob J. Ragsdale

Michael H. Ralphs
Dan D. Ratliff

C. Hardy Redd

Janis J. Reimers

William A. Reimers

Steven T. Revie

R. Dwayne Rice

Matt J. Ricketts

Kara Ricketts

Ronald E. Ries

Laurence E. Riordan

Walter M. Risse

Larry R. Rittenhouse

Leona M. Rittenhouse

L. Roy Roath

Winthrop P. Rockefeller

Ernest D. Romero

James T. Romo

Robert L. Ross

Susan J. Rottman

Elno D. Roundy

John M. Row

Charles B. Rumburg

Philip R. Rumpel

Brad Russell

Faith E. Ryan

Warren K. Sandau

Kenneth D. Sanders

H. Reed Sanderson

Gary D. Satter

Ted Scherer, Jr.

Al F. Schlundt

Harold B. Schmidt

Joe M. Schmidt

Martin R. Schott

Charles M. Schumacher

Milton Sechrist

Donald J. Seibert

Douglas V. Sellars

Daniel L. Sharp

David E. Sharp

Gail E. Sharp

Weldon O. Shepherd

John A. Shrader

M. Silia

Phillip L. Sims

Chester L. Skilbred

Jon M. Skovlin

Michael A. Smith

Terry J. Smith

Sydney E. Smith

Floyd L. Snell

Carol A. Sparks

Thomas L. Sparks

Steven M. Spencer

Stan Starling

Al Steninger

Anne Steninger

Warren J. Stevens
Kimberli R. Stine

Robert L. Storch

James Stubbendieck

Sherman R. Swanson

Faisal K. Taha

John A. Tanaka

Ann F. Tanaka

Wayne F. Taylor

Nora Taylor

Charles E. Taylor

Paul G. Taylor

David P. Tidwell

Stan Tixier

Lynn D. Todd

T. W. Townley-Smith

George T. Turner

Cynthia A. Tusler

Albert L. Van Ryswyk

Larry W. Van Tassell

Dee Moore Vanderburg

James Waggoner

Robert E. Wagner

A. H. Walker

Mrs. A.H. Fred Walker

David G. Walker

Ronald M. Walters

Carl L. Wambolt

Clinton H. Wasser

Fred L. Way

J. Wayne Weaver

Shawn W. Weishaar

Noel H. Wellborn

Gary Westmoreland

Steve Whisenant

Gerald D. Widhalm

Kay W. Wilkes

W. A. Williams

Calvin E. Williams

Clayton S. Williams

Robert E. Williams

Thomas M. Williams

Robert M. Williamson

Terry Wilson

Leaford C. Windle

Gale L. Wolters

Jerome H. Wysocki

Jim D. Yoakum

The bold indicates sustaining life membership in the Society. 


\title{
Viewpoint
}

\section{Range: What's in the word?}

\author{
By Mort Kothmann
}

The terms range and rangeland define our profession and the lands we manage. For over 3 decades, our profession has been debating whether range is defined as a use of the land for livestock grazing and rangeland is a kind of land independent of its use or is range also a kind of land or are range and rangeland both defined by use. How we define these terms is important to how we define our profession and the names that are most appropriate for our society and publications.

Major John Wesley Powell (1878) was credited with the first recognition of range as a different kind of land that was not suitable for cultivation or forestry, but was well suited to production of grazing livestock. Thus, range was defined as extensive, generally unfenced, natural grazing lands. This was the definition and common usage at the time the American Society of Range Management (ASRM) was formed. The primary focus of the new profession was to inventory, assess, and monitor range for the maximum sustainable utilization of forage and production of livestock. Other uses and products were of minor importance. The ASRM was conceived as an interdisciplinary society with the focal point being the management and conservation of range land for the production of forage.

The term rangeland, as one word, did not come into common use until after it was defined in the $2^{\text {nd }}$ edition of the Glossary of Terms Used in Range Management in 1972. Dr. E. J. Dyksterhuis, writing for encyclopedia Britannica, defined "rangelands" as a kind of land where the natural potential vegetation (climax) is suitable for grazing. The key concepts for the definition of rangeland were grazing lands and climax. Plant succession on rangelands should lead to improved grazing values; whereas, succession on forestland should lead to a decline in grazing values as tree cover increases. Grazing was considered as the primary disturbance causing shifts away from climax type vegetation. The role of fire in directing plant succession was not adequately considered. Dyksterhuis' goal was to define rangeland as a "map able" land unit distinctly different from forestland and cropland.

In the $3^{\text {rd }}$ edition of the Glossary of Terms Used in Range Management (1989), the definition of rangeland was changed to delete the reference to suitability for grazing, but retained the concept of natural potential (climax) vegetation as the sole criteria. The wide spread adoption of multiple stable states for potential vegetation rather than cli- max equilibrium theory raises a question as to what criteria we should use to define rangeland. If range and rangeland are to be defined as a "kind of land" not based on use for grazing or browsing animals, what are the criteria that we use to classify then? One alternative is to define them based on what they are not, i.e., rangeland as any type of land supporting natural vegetation that is not defined as forest.

During the business meeting at Kansas City, President Rod Heitschmidt announced in his inaugural address that he is going to open a dialogue within SRM on the issue of the names for our society and publications. This issue has emerged several times over the past 54 years. The society name has been changed twice and the name of one of our publications has been changed once. The last of these changes was made three decades ago.

During the past year I have discussed the issue of names with numerous persons. The most common response on the issue of the Society name is "What we call ourselves is not really that important; I am not in favor of changing our name." As our dialogue proceeds, I generally find that behind that statement is a strong unexpressed resistance to changing the name. It is almost like people are saying, "I know we probably need to make some changes, but don't change our name! Names are not unimportant!"

In reality, names are very important. Historically, a person's name "defined" who they were. Character, tradition, and family pride are all associated with the family name. People who immigrate from one culture to another frequently change their name to match the new culture. Names are extremely important to companies. Enron agreed to pay over $\$ 100,000,000$ to get its name on a baseball park in Houston. Now the Houston Astros have agreed to pay Enron over $\$ 2,000,000$ to take it off because of the negative values associated with it. Any entity, be it a person, place, object, concept, or value, must have a name or it goes unnoticed. It is difficult to communicate with a person who is not listed in the directories or about a place that is not on the map and an object, concept or value without a name. Names are essential for us to communicate.

As we consider the names for our society and publications, I suggest the following questions. (1) What were the issues and management paradigms that shaped the profession when SRM was formed and the current names were chosen? (2) Have the issues and management paradigms 
changed over the past 50 years? (3) What changes have occurred in society's views, perceived needs, and values over the past 50 years? (4) What changes can we expect in the profession, the professionals, and society over the next 30 years? (5) What names might we consider that would best communicate, "Who are we and what we expect the society to become in the next 2-3 decades?" (6) What are the key words and concepts for our profession today: land, stewardship, conservation, water, landscape, habitat, management, use, extraction, exploitation? (7) What defines our profession? Is it is the land or the vegetation or is it the use of the land and the vegetation that defines who we are and what we do as a profession? (8) What is the basis for aggregating a diverse collection of cover types under the term rangeland if it is not potential for grazing or browsing?
We need names that will accurately and effectively communicate the message that we want to send to prospective members of our professional society, to other professional societies, and to the general public. Box (Rangelands, December 2001) describes our mission as the "Ministers to the Land" and writes of the evangelistic land ethic of the pioneers of range management as they "listen to the land and then dare to become its voice." Does "range" as, "the use of land by livestock and wildlife accurately describe our mission?"

Note: Viewpoints expressed are those of the individual author and not the entire SRM membership.

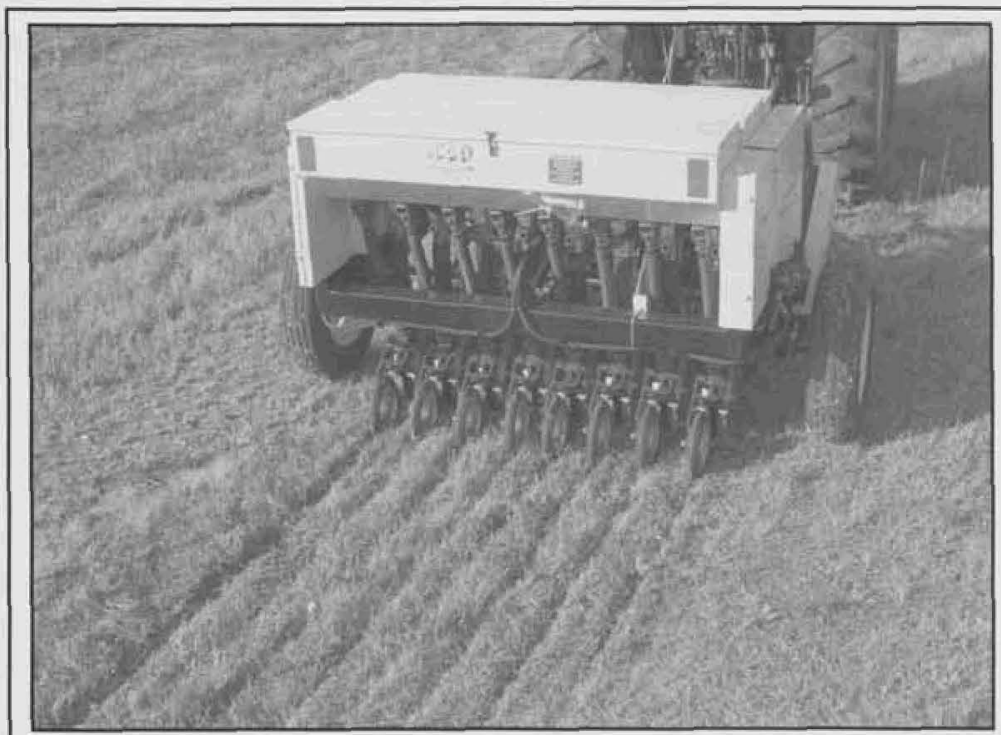

N14 TV 9 The "Trillion" - shown at right, is the ideal 1 1 broadcast seeder for wildflowers, turf grasses, and fluffy/chaffy prairie seeds. Unit has three types of seed boxes and combines the truax seed delivery system with two Brillion cultipack rollers.

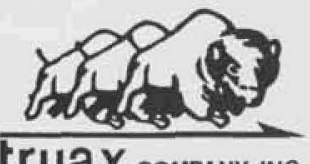

IrUaX COMPANY, INC. 4821 Xerxes Ave. No, Bldg. B Minneapolis, MN 55430

\section{PERFORMANCE.}

Superior design, top-quality materials, and meticulous hand-built construction are what set truax seeding equipment apart from the competition. You'll find these in every truax seeder from the small, hand-cranked, Seed Slinger that lets you broadcast fluffy seeds and grasses together by hand, to the famous Flex II seed drill pictured at left, which interseeds native grasses, turf grasses, fluffy seeds, small grains, wildflowers, even legumes.

The result is outstanding seeding performances even in the most challenging environments! - and durability that will last for decades.

If you want dependable seeding performance, you want a truax!

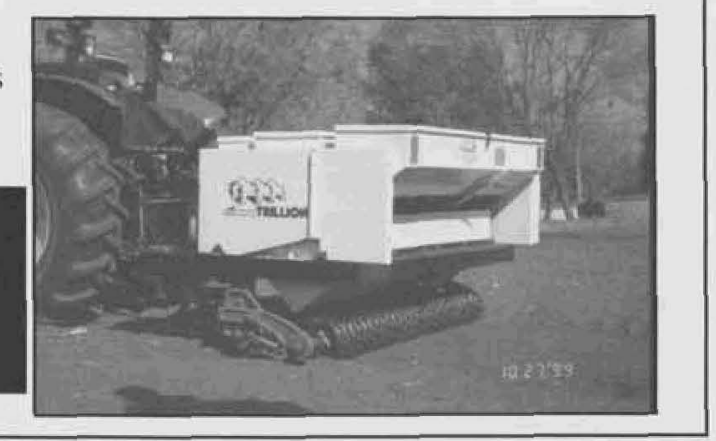




\section{Book Reviews}

Conservation Tillage and Cropping Innovation: Constructing the New Culture of Agriculture. By Shankariah Chamala and C. Milton Coughenour. 2000. Iowa State University Press. 360 p. US\$59.95 hardcover. ISBN 0-8138-1947-4.

A long day with the sun in your face, the wind at your back, the whole time choking on dust, either walking behind a horse, a mule, an oxen, or sitting upon a tractor pulling a plow, has long been the image of what it means to be a farmer. The plow is such a long-standing symbol of agriculture that even the National FFA Organization has incorporated it into their emblem. But no-tillage and conservation-tillage farming are slowly eroding the belief that plowing is necessary to produce a good crop in a relatively weed-free environment. These practices are challenging what the authors view as plow culture, and attitude within the culture of agriculture, which they use to describe the beliefs historically held by agricultural producers. In Conservation Tillage and Cropping Innovation: Constructing the New Culture of Agriculture, a new belief is tracked, one in which the farmer is an inventor, and a scientist, not a hayseed.

This book sets out to answer two questions about the adoption of no-tillage and related forms of conservation tillage. The questions are (1) how did this revolution take place, and (2) why did it take place at all? These questions are answered in detail. The authors use examples from the United States, especially Kentucky, which leads the nation in the practice of no-tillage cropping, and from Australia, particularly Queensland. They present a comprehensive look at the histories of these areas and provide individual case studies demonstrating the adoption and spread of notillage farming and conservation tillage among farmers.

This book is comprised of eleven chapters, plus a bibliography, an appendix of acronyms, and an index. The first chapter introduces the reader to no-tillage farming, how and where it started, and the need for it. The subsequent chapters deal with the evolution of technologies and how they have enabled farmers in both Kentucky and Queensland to establish a new agricultural system using different farming techniques. These technologies are examined through individual case studies of farmers in these areas. The case studies examine the ability to grow crops on ground previously judged too erodable, by increasing the water holding capacity of their soils, allowing a broader range of crops to be grown. This ability potentially enables farmers to farm more profitable crops, thereby increasing their incomes. In addition, the reader also receives an education on constructing new cropping systems and the implications for research, development, and extension. The last chapter is an overview of the "new agriculture of conservation cropping: present and future."
The authors state that this book should open the eyes of technical people on how change really occurs. The authors use case studies to provide an in depth look at why an individual farmer will adopt a particular farming system, and the importance of research, in aiding the adoption of any farming system. A good technical idea may or may not be a good practice for a particular farmer. Even though it may be a good practice, it could be troublesome or uneconomical to adopt. In fact, in the book there was hardly a case where an idea was adopted unchanged; either it was modified slightly or greatly and the resulting farming system was different than that originally envisioned. Conservation Tillage and Cropping Innovation: Constructing the New Culture of Agriculture, does open the eyes of its readers. The author's presentation of the overall history of plow culture helps the reader understand why farming is the way it is, and how it has had long-term effects on our perception of farming.

The book contains a great deal of detail on pesticide use and equipment modification needed, developed, and used by farmers. I found the book valuable in furthering my understanding of conservation tillage, as well as farming in general. Not only are the how and why given, but also the what and where. Numerous crops are mentioned, which suggests the versatility of conservation tillage for crops such as sorghum, corn, wheat, soybeans, and some others.

Conservation Tillage and Cropping Innovation: Constructing the New Culture of Agriculture is not only a strong systems management and agricultural sociology book, it provides an excellent definition of sustainable agriculture, exemplifying it as: "his tillage system must be satisfactorily sustainable and profitable as he perceives it." Often the need to adopt conservation practices is greatest where it is most needed, in highly erodable and often shallow soils. How the farmer perceives a need to adopt will determine the manner in which he farms.

The Palouse Prairie around Pullman, Washington is often credited with having some of the best soils in the nation. In some places the soil is as deep as fifty feet. This region is Washington State's primary dryland wheat producing region, and because of the soil depth, farmers often perceive these soils as inexhaustible. No-till has been slow to catch on here and in other regions of the nation fortunate enough to have deep soil, but it is catching on. Even in these regions farmers are beginning to discover the benefits of conservation tillage and no-tillage systems.

Any individual involved in teaching or establishing an agricultural culture, especially those looking to work in developing countries, would do well to read this book. It would be valuable not just to sociologists, but to anyone interested in conservation tillage systems. 
In the early 1950's plow culture reigned unchallenged as the superior method of farming, but by the end of the millennium, no longer unchallenged, it began to retreat as minimum tillage agriculture surfaced, agriculture that reduced erosion and the mysterious disappearance of valuable cropland. I once heard a professor describe the farming around Pullman as "not really wheat farming, but wheat mining," referring to the appearance of clay knobs dominating much of the hilly, silt-loam dune landscape. No-tillage farming is slowly eroding the dominance of the plow in agriculture. The authors appear to view the innovators' role as plowing out the old culture of agriculture like an unwanted weed, and with their no-tillage tools, sowing the seeds of agriculture's likely future. If they are unsuccessful, one cannot help but wonder if there will be another dust bowl in that future.-Chase W. Metzger, Washington State University, Pullman, Washington.

Stolen Harvest: The Highjacking of the Global Food Supply. By Vandana, Shiva. 2000. South End Press, Cambridge, Massachusetts. U.S. $\$ 40.00$ hardcover. ISBN 0-89608-608-9.

Vandana Shiva. For those individuals not familiar with this international name, Shiva is associated with descriptors that can make a room full of ranchers grow hungry for a good roping - academic scholar, radical activist, eco-feminist. So why would the average range management professional in America be interested in what a radical activist from India has to say? First of all, Shiva is not just some bleeding-heart liberal eating co-op granola in her VW bus while on the way to a WTO protest. She is a physicist, the Director of the Research Foundation for Science, Technology, \& Natural Resource Policy, an Alternative Nobel Peace Prize Recipient, and a leader of the International Forum on Globalization. Secondly, as professionals that care for our nation's natural resources, we should have some awareness of how Western-style agriculture, and therefore Western industry, is affecting other nations' resources. Lastly and most importantly, as global business leaders and consumers, Americans have an ethical obligation to be good neighbors and proper land stewards anywhere that we profit.

Vandana Shiva's latest book, Stolen Harvest, is a brief yet thought-provoking critique of some mutual incompatibilities of Western industrial development and Eastern culture. Throughout the book, Shiva desperately attempts to open our eyes to the things we don't see or don't want to see in the wake of the West's global economic prosperity-increased economic displacement, marginalization, exploitation, and social violence. Within each chapter, Shiva addresses the difficult ethical and moral controversies that surround issues such as commercial agriculture and aquaculture, biotechnology, genetic engineering, and international gene patent laws.

She poses perplexing questions such as, "if a plant trait has been bred by indigenous farmers for generations and then agribusiness firms isolate the trait's gene, modify it, and insert it into another plant for disease-resistance, is it fair that agribusiness firms receive exclusive patent rights and royalties from that gene, plant, or new variety?" Is it ethically right to patent Nature for private profit?

Next, Shiva enters into the debate about the global food supply and her expressed belief that food shortage is a political issue of inequitable distribution and unfair trading practices rather than a simple case of inadequate production. As an unfair trading practice, many agricultural areas in Third World countries are pressured by international corporations or government subsidy programs into growing specific commodity crops for increased capital, thus decreasing the nutritional and varietal diversity of local diets. In countries like India, the conversion of diversified, subsistence agriculture to monocultural, commodity crops have made it difficult for rural communities to maintain proper health despite increases in local income. Shiva maintains, as in her earlier works, that by changing the role and methods of crop production in rural villages, modern (capital-intensive) agriculture has instigated undeniable negative social impacts, putting both rural and urban culture and social order at new risks, especially for landless peasants, including women, and children.

Although complementary to her other books, Stolen Harvest seems more like an attention-grabbing introduction than a sequel. Shiva's other works include more in-depth analyses of industrial development, global corporations, foreign aid programs and their social effects, and grassroots socio-environmental movements in the developing world.

I would, therefore, recommend this book to any budding environmental sociologist \& natural resource manager, conscious consumer, or activist concerned with the effects of globalization. To obtain a more comprehensive picture of international development in non-Western societies, I would recommend supplementing Stolen Harvest with one of Shiva's previous works, Staying Alive: Women, Ecology, and Survival, The Violence of the Green Revolution, or Ecology \& the Politics of Survival: Conflicts Over Natural Resources in India, or with other authors' literature with a more conservative perspective.

The main intentions of Stolen Harvest are to (1) make you think - to contemplate what your professional, business and consumer choices do to other individuals and environments outside your backyard, (2) let you know how multinational corporations and our nation's representatives are acting in others' homes, and (3) encourage your response, and help us begin to dissolve some of the apathetic attitudes that we as Americans have acquired as rich inheritors of $20^{\text {th }}$ Century industrialization. I feel that in her own way, Shiva has tried to educate others to the wisdom of humanitarians such as Mohandas K. Gandhi when he proclaimed, "There is no beauty in the finest cloth if it makes hunger and poverty."- Olivia Forté-Gardner, Dept. of Natural Resource Sciences, Washington State University, Pullman, Washington. 


\section{An Open Letter To The Members Of The Society For Range Management}

To warn you: I have no academic training in any kind of Range Science. However, I have reason to be very aware of the worldly importance of your profession.

For all of my $80+$ years, I have lived in one type or another of fragile terrain: first, a Southwest Louisiana waterway, which came to include The Intracoastal Waterway/Canal, salt water intrusion and chemical industries; then, Family ownership of 5 acres of mountainside land in Southern California, which threatened to become prime development land, and, finally, 5000 acres of North Central Texas ranch land. Meanwhile, forty years in New Orleans.

It was at the latter that I crossed paths with Jerry Payne, head of our County S.C.S., as the N.R.C.S. was titled in 1984.

Jerry suggested that I join the Society for Range Management, which $I$ did, and so began receiving The Journal and Rangelands, both of which I diligently read. The Journal came with one's membership then. I am very glad that it did because, even though I related more willingly to Rangelands, I did study through the Journal. In that way, I came to realize the breadth and depth of S.R.M.'s earth related endeavors.

It could be that each of you has a relatively narrow speciality - but, not all of you - and, most assurredly, all put together constitute the Earth.

Please realize-stop and think-in your profession you work with all of the sites: from deserts to forests; all of the soils, climates and conditions in between: very dry; very wet; sand; clay; flat; very rough; alluvial; rocky; temperature extremes as well as temperate zones. It seems to me that you are the only organization which works with all of the elements. You encompass the Planet, and as is the health of the Planet, so is the health of Civilizations.

Your interests are far from being as 'zeroed in' as those of many conservation or ecological associations. Yet, those have their places. They need to be addressed and will always tug at peoples' heart strings and purses.

I am extremely heartened to hear and read of S.R.M.'s increasing net-working. I do believe that S.R.M. can greatly incease its effectiveness by joining forces with professionally legitimate conservationists - public or private-whose energies are directed toward specific areas.

Further, I believe that S.R.M. should be in the position of Advisor or Leader, depending on the situation.

The more S.R.M. can make itself known in Legislatures and in Congress the better. Lawmakers et al. and the Public need to hear an Authority which is not pushing one agenda, but which speaks from long years of research and experience and application in the broadest area of Conservation. You are that Authority.

I repeat: as this Planet's Natural Resources fare, so fare Civilizations.

I hold the Society for Range Management in very high regard.

Sincerely,

Mrs. Nellie C. Wilson

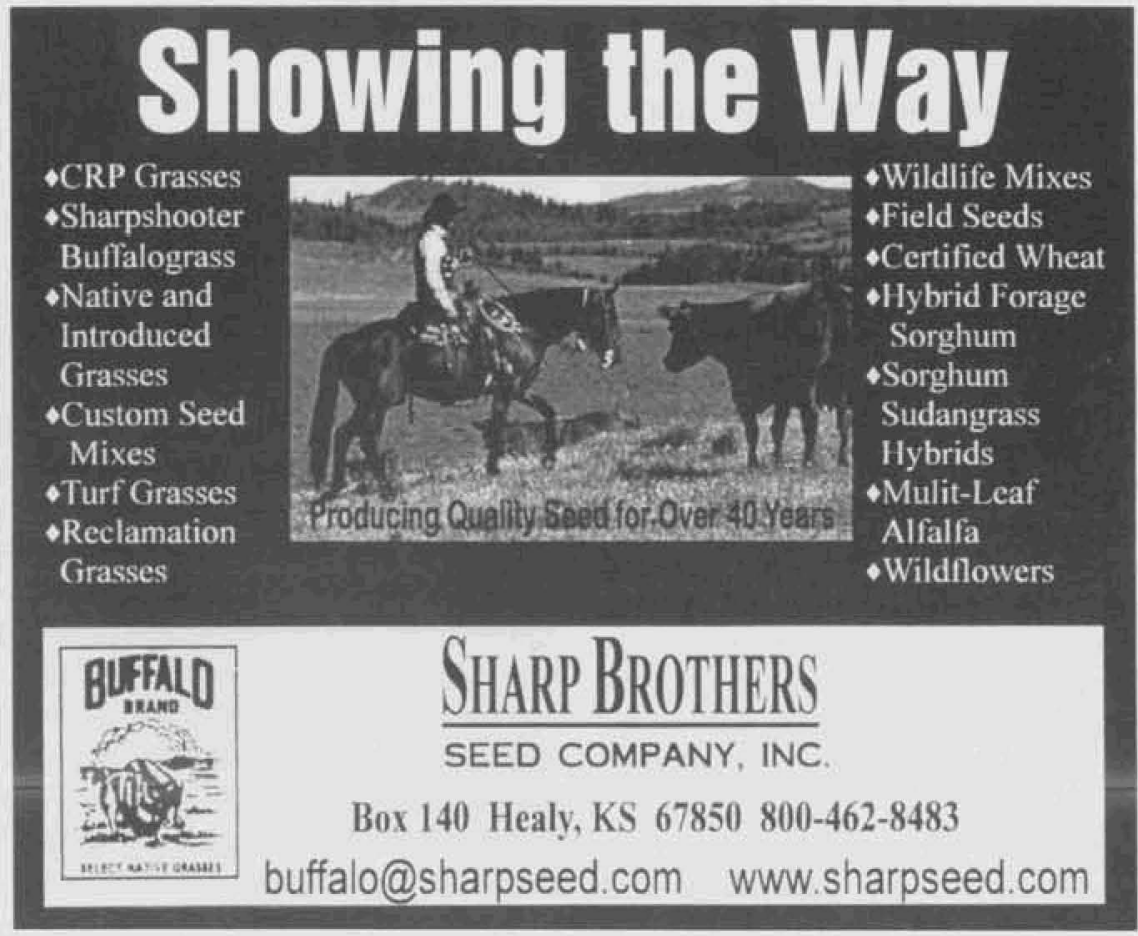




\section{Board of Directors' Meeting Highlights}

The Society for Range Management 2002 Board of Directors' Meeting was held at the Marriott Hotel in Kansas City, MO. President Jim O'Rourke presided.

EVP Sam Albrecht reported that the main focus for 2002 will be on membership recruitment \& retention. He introduced Leonard Jolley, who will be replacing Jeff Burwell as the Public Affairs Manager at SRM headquarters. Jølley will be joining the staff in Lakewood at the end of March. O'Rourke reported that both BLM and Forest Service have expressed an interest in placing a staff person at SRM headquarters. BLM's goal is to have a staffer in place at SRM headquarters in October or November of this year, with primary focus on assessment \& monitoring.

SRM Washington Representative Deen Boe reported that 2001 witnessed continued improvement in SRM's ability to raise awareness of rangeland management issues and to affect policy at the national level. The bulk of the activity has been in rangeland assessment and monitoring; exploration of SRM options for expansion of our presence on the Washington, DC scene; the 2002 Farm Bill; Seeking Common Ground; Renewable Natural Resources Foundation; plant materials \& native seed issues; establishing a working network with other professional natural resource societies; and facilitating key contacts for SRM leadership and others.

The SRM Strategic Plan was adopted and will be implemented.

EVP Albrecht presented a detailed report on headquarters office location. After discussion, it was determined that there was no clear advantage to moving the office outside the Denver metro area.

EVP Albrecht presented a report on current cost to service life memberships. This program currently creates an annual deficit of just under $\$ 10 \mathrm{k}$ per year, and recommended that the Board consider increasing dues for life members.

A review of the 2001 year-end financials, including investment fund performance and 2001 operating budget has a projected $\$ 73.8 \mathrm{k}$ deficit.

The Board approved the reaccreditation of the University of Idaho for a 10-year period.

The Board approved the Range Consultant Certification Panel's request to change their fee structure.

The Student Activities Committee reported that they have developed a Graduate Student Poster Contest to be held at future annual meetings and that funding for the winners has been secured from Dow AgroSciences. They have also secured funding for future Graduate Student Paper contests.

The Board agreed to administer funds for the National CRM Team for a yet to be determined fee structure.

The Endowment Fund Board of Governors Silent
Auction raised approximately $\$ 14 \mathrm{k}$ at this meeting.

The Board accepted the Nominating Committee's recommendation for slate of candidates for 2003. They are: for Second Vice President: Mike Stroud and Angela Williams; for Directors: Lynn Drawe, Jeff Burwell, Jim Stine, and Allen Rasmussen.

The newly developed Executive Vice President Employment Agreement was reviewed and approved.

The 2002 Operating Budget was approved with deficit to be covered from investment funds.

The Board approved a dues increase for regular members in the amount of $\$ 10$ per year beginning in 2003. Annual increases will be reviewed August $1^{\text {st }}$ of each year. Dues for Life \& Life Family members will be increased to $\$ 1,500$ and $\$ 1,750$, respectively, and Commercial member dues will be increased to $\$ 500$, effective immesiately. All other dues increases will take effect in January 2003.

The Board approved the Professional Affairs Committee's recommendation to adopt an updated Standards of Conduct for SRM Members Providing Public Service and Code of Ethics.

The Resolution on the 1995 Farm Bill has been removed from the SRM Policy, Position \& Resolutions document.

The new committee structure was presented. Six divisions with committees working under each. Committees will need to develop vision, operating procedures, etc. to continue as a committee. Board representative roles have changed. Coordinators will rotate annually, or perhaps every 2 years. Committees exempt are: Finance, Elections, Accreditation, Range Consultants Certification Penal, CPRM, Nominations, \& Awards. The final proposed plan will be completed for review at the Summer Meeting.

The Board adopted the mission statement from the Video Task Group.

The Arizona Section encouraged the Advisory Council and the Board of Directors to attend the SRM Summer Meeting, August 12-14, 2002, in Flagstaff, AZ.

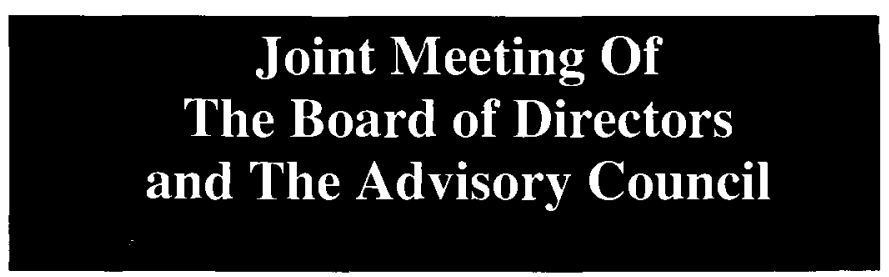

The Joint meeting was called to order at 4:00 p.m. by AC Chair Grant Stumbough. The Advisory Council presented the following recommendations to the Board:

Recommendation \#1: The Advisory Council recommends that the Board and staff help improve communications. Advisory Council to provide detailed list of suggestions to SRM headquarters \& Rod Heitschmidt.

Recommendation \#2: The Advisory Council recommends that the Board provide the Sections a list of projects with 
costs that they could fund besides the Washington, DC presence. Albrecht will provide list of projects to AC Chair and send letters to Sections.

Recommendation \#3: The Advisory Council recommends to the Board that the 2006 Annual Meeting be held in Calgary, Alberta. MOTION by Budd, second by Kirby to approve. MOTION by Linebaugh, second by Budd to table for further discussion. After discussion, it was determined that a thorough review of the proposal and site visit by headquarters staff has not been completed. Decision as to location of the 2006 Annual Meeting will be determined once this has been completed and report made to Board.

Recommendation \#4: The Advisory Council recommends that the Board take action to contact the Natural Resource Conservation Service to complete rangeland inventory for National Rangelands Inventory. MOTION by Budd, second by Linebaugh to approve. Passed unanimously. SRM President will write letter in support of NRI.

Recommendation \#5: The Advisory Council recommends that the Board allow a name change from the California Section to the California-Pacific Section to include all the lands in the Pacific not currently associated with the Australian Rangeland Society, the Mexican \& Pacific Northwest Sections of SRM and Alaska. MOTION by Budd, second by Linebaugh to approve. Passed unanimously.

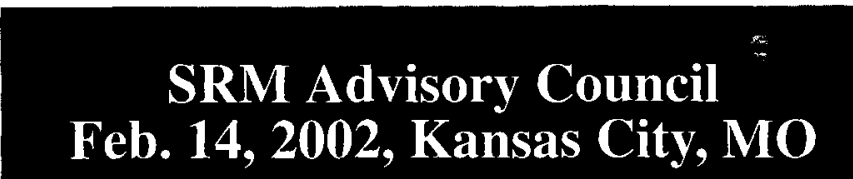

\section{Submitted by Tammy DeCock}

Twenty Sections represented (Mexico absent). Minutes from February 2001, Kona, HI and July 2001, Elko, NV were approved.

Presidents Report--President O'Rourke stated he has made extra effort to communicate over the past year; however, we are still struggling. The Chair and Chair-elect of the $\mathrm{AC}$ have been included on communications between the BOD with emails and invited to Executive Council meetings. A BOD representative attended Section meetings and the Trail Boss News was used to communicate with membership. The Advisory Council did not have a quorum at the summer meeting in Elko. Only 4 Section Reports were sent in from sections this year. Good Section representation at this meeting; however, Jim pointed out that only 2 items on the AC Agenda were generated by Sections.
A discussion followed and it seems members of the AC are unsure of what was needed from them and requested a check list with due dates. Less than half of the $\mathrm{AC}$ members attending had seen the Advisory Council Handbook before today.

Annual Reports are distributed at the Membership Meeting during the Annual Winter Meeting. A discussion followed on how we could better highlight and/or distribute the Section Reports so they are seen by more and improve the reports effectiveness.

Section Newsletters should be sent to other sections. Please add the members of the Board of Directors and Advisory Council Chair and Chair-elect to your Section Newsletters mailings. It was suggested to post Section Newsletters on SRM's Web page.

Political Networking-Deen Boe reported that SRM was successful in gaining language in the House's Interior Appropriations Bill on Rangeland Assessment and Monitoring. SRM has established good contacts in DC; we now also need good legislative contacts at the state level. A personal relationship from someone at the Section level is needed and would really have impact. Deen would share what SRM is working on in DC with the Section legislative contacts, as well as them sharing what is going on and need at the Section level.

Item of concern from TX Section: The National Resources Inventory (NRI) on Rangeland is not being planned to be conducted by NRCS this year due to possible other workload priorities that may be created by the New Farm Bill.

SRM Presence in Washington D.C.--President O'Rourke reported that we have been investigating how can we most economically and effectively be in DC. This would cost $\$ 7,500$ for an office in the building. With setup costs of computer, furniture, etc it is estimated to cost $\$ 12,000$ for the first year. A Washington DC presence is our Parent Society's \#1 priority. If your section would be willing to help fund this project, contact Sam.

Discussion/suggestions followed with request to give sections a list of 5 items that Sections could financially help with. SRM's activities in DC have done more to elevate the visibility of the Society then anything. BOD is not putting a mandate on Sections. Some Sections need more assistance at home at the local level. The local legislative contacts from Sections, are as important, if not more important than dollars.

Nebraska Section- proposes to increase young professional award age to 40 . Reasoning: the accomplishments required to obtain this award usually takes until most individuals are in their mid 50's to achieve. Recommendation for the Awards Committee to consider this before recommendation from the AC. 
EVP report-Sam Albrecht reported that we are presently fully staffed in our Lakewood office. Leonard Jolley will be filling the position Jeff Burwell had at the end of March. It has been decided to keep our Parent Society office location in the Denver area. We are working on an office in DC. Our SRM new Web site is about ready - www.rangelands.org Our new server is in, with a few transition problems being worked out. Membership renewals were one of these problem areas. New server and web site will allow members to sort and download addresses. It will be secure and require a membership number and password to access. The EVP work plan is based on Strategic Plan.

Budget-John Tanaka and Bob Budd reported that we ran a deficient last year but were close to financial predictions. If we use dues to pay for everything, then dues will need to increase. If we implement any of the special projects we have identified and pay for these special projects from dues, then dues will need to be increased. Presently we are spending $\$ 60-70,000$ that we do not have an income for. Presently it is costing $\$ 47$ per member for benefit being received. BOD is coming to the sections requesting guidance and asking for membership input on raising dues.

Committee Restructuring-Rod Heitschmidt reported that presently we have 37 committees with 407 committee positions in an organization of 3,500 members. We need to streamline. Inter-committee communications has not always been good. The ultimate goal is to improve the function of SRM, make your lives easier, and improve efficiency in terms of time. Rod is suggesting we restructure and organize committees under the 6 functional areas in the Strategic Plan. Six committee chairs have agreed to serve as a committee to orchestrate committee restructuring. Rod would like to implement the new committee structure change at our Annual Meeting in Casper.

Partners and Affiliations--Key is at the local level for partnering. Have been in contact with 50 groups. Partnering with other organizations we can effect direction and assist the goal of SRM.

Journey to Change presentation from Kendal Johnson

Vote by ballot for 2006 Annual Meeting Location-14 for Vancouver, 24 for Calgary.
Endowment Fund-Chuck McGlothlin requested that someone from the Advisory Council help with Section contact to get items to the Endowment Fund Silent Auction. The AC indicated with an obvious majority, by voice, they would like to see the Silent Auction continue. In 1999, the Endowment sponsored a membership campaign and gave 185 gift memberships out at a cost of $\$ 10,555$. To date 37 renewed their membership resulting in $20 \%$ renewal rate. Chuck requested a recommendation from the $\mathrm{AC}$ to repeat the gift membership campaign with Sections responsible for follow-up. Vote was 12 for and 20 against repeating gift membership campaign.

California Section-The AC approved a name change from California Section to California/ Pacific Section. The California-Pacific Section of the Society for Range Management shall include all of the land in the Pacific Basin not currently associated with the Australia Society for Range Management, the Mexico and Pacific Northwest Section of the Society for Range Management, and the state of Alaska. The AC approved unsectioned SRM members within the Pacific Basin shall become members of the California-Pacific Section.

GLCI update-Leadership has to be enthusiastic and positive since the Grazing Land Conference in Billings with 860 people attending. Only $2 \%$ of NRCS personnel were left to work on rangelands, after the compliance efforts and budget cuts. GLCI has been working for funding to be used on grazing lands only and on a voluntary approach.

Developed 5 points in a stand-alone Bill separate from the Farm Bill: increase funding for technical assistance; initiative in research; education for extension to provide courses for producers and NRCS together; incentive program to reward producers for doing the right thing; and agreements between producers would be confidential

The Second Grazing Land Conference is planned for Dec 7-10, 2003 Nashville, TN.

Sandra Fabritz from Arizona was elected as Advisory Council Chair Elect. 


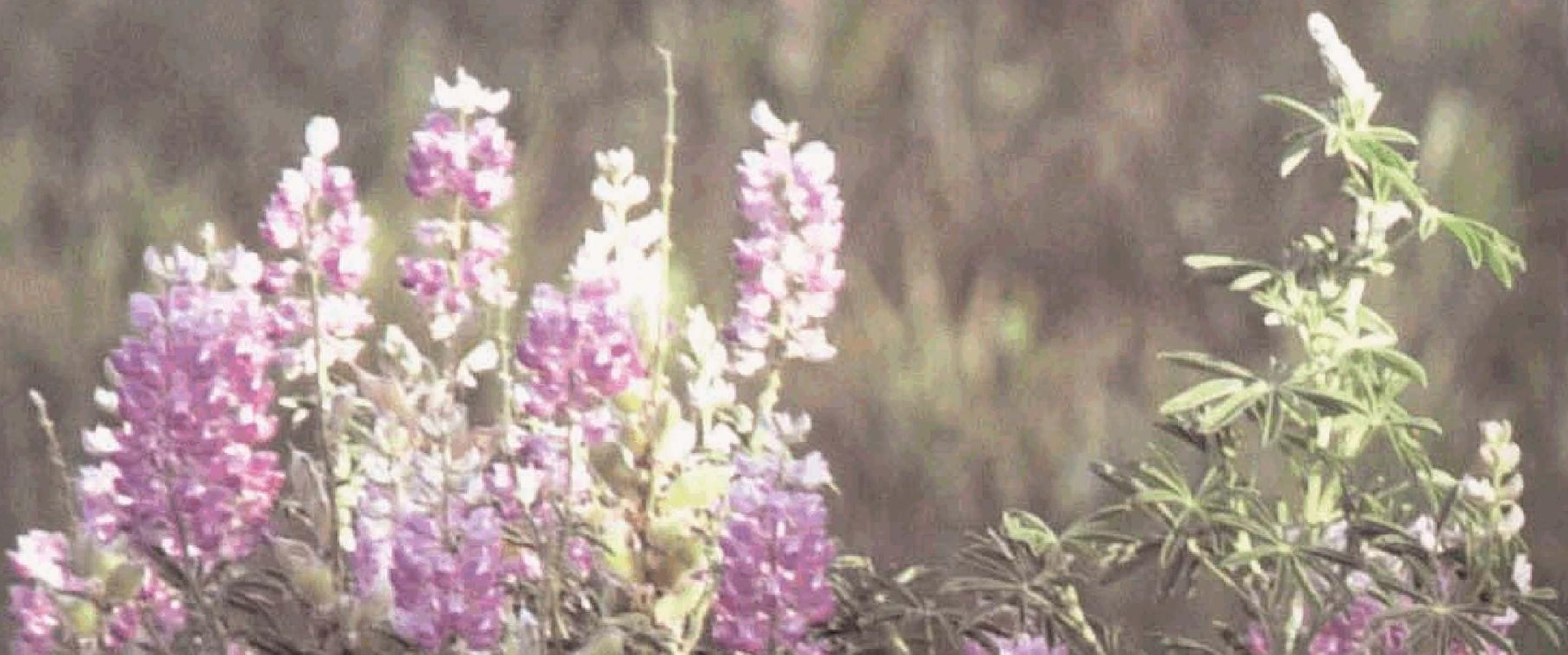

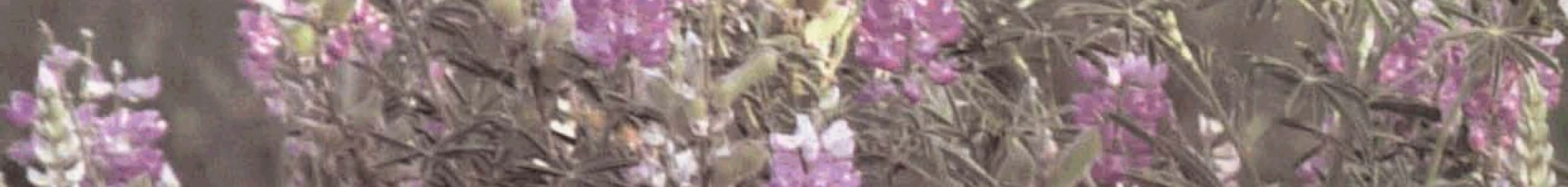

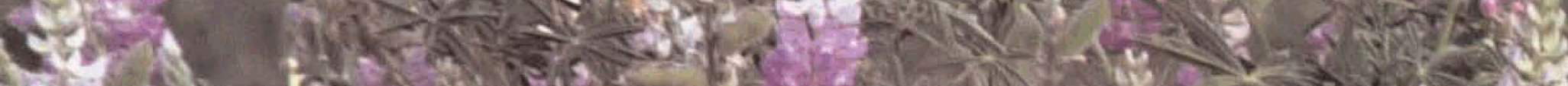
It h

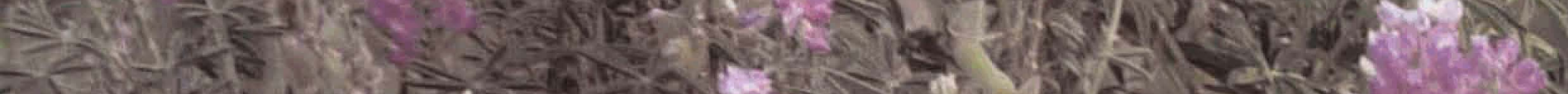

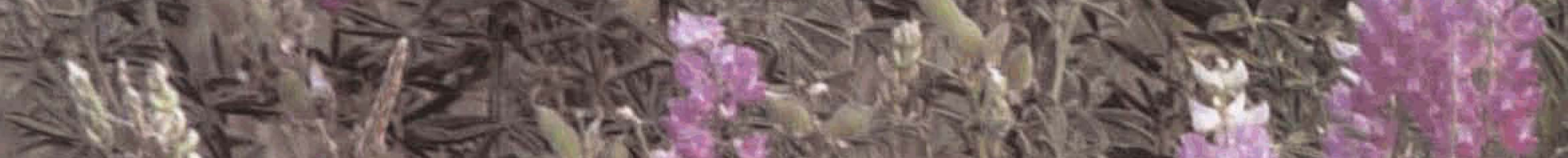

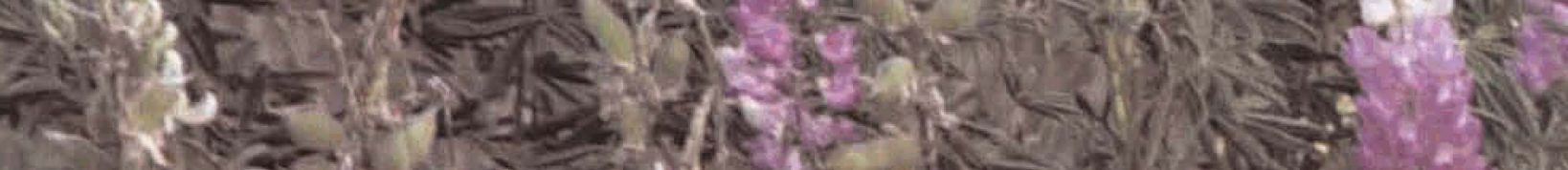

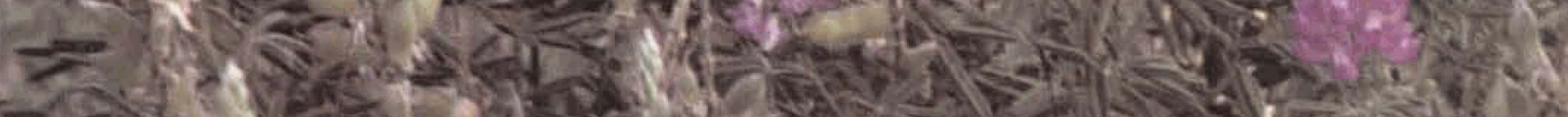

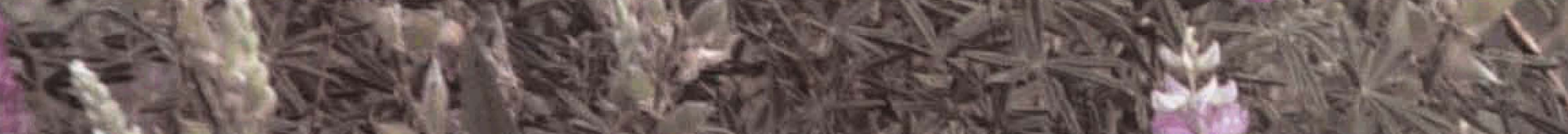
H.

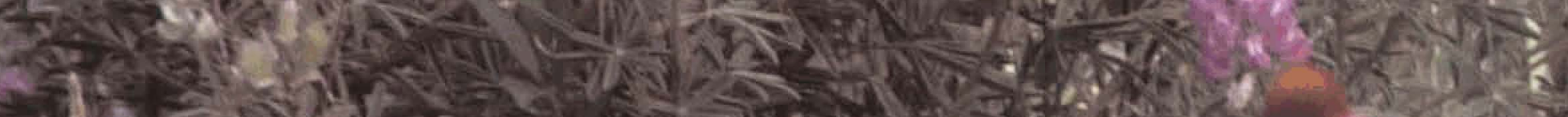
17. -1. 